\title{
Assessment of Protein Quality, Lipid Metabolism, Hepatic Transcriptome and Safety of a Silver Carp (Hypophthalmichthys molitrix) Derived Sarcoplasmic Protein Powder.
}

\author{
Derek Cole Warren \\ West Virginia University, dwarren2@mix.wvu.edu
}

Follow this and additional works at: https://researchrepository.wvu.edu/etd

Part of the Food Biotechnology Commons, and the Molecular, Genetic, and Biochemical Nutrition

\section{Commons}

\section{Recommended Citation}

Warren, Derek Cole, "Assessment of Protein Quality, Lipid Metabolism, Hepatic Transcriptome and Safety of a Silver Carp (Hypophthalmichthys molitrix) Derived Sarcoplasmic Protein Powder." (2020). Graduate Theses, Dissertations, and Problem Reports. 7745.

https://researchrepository.wvu.edu/etd/7745

This Dissertation is protected by copyright and/or related rights. It has been brought to you by the The Research Repository @ WVU with permission from the rights-holder(s). You are free to use this Dissertation in any way that is permitted by the copyright and related rights legislation that applies to your use. For other uses you must obtain permission from the rights-holder(s) directly, unless additional rights are indicated by a Creative Commons license in the record and/ or on the work itself. This Dissertation has been accepted for inclusion in WVU Graduate Theses, Dissertations, and Problem Reports collection by an authorized administrator of The Research Repository @ WVU.

For more information, please contact researchrepository@mail.wvu.edu. 
Assessment of Protein Quality, Lipid Metabolism, Hepatic Transcriptome and Safety of a Silver Carp (Hypophthalmichthys molitrix) Derived Sarcoplasmic Protein Powder.

Derek C. Warren

Dissertation submitted to the Davis College of Agriculture, Forestry, Natural Resources, and Design

at West Virginia University

Doctor of Philosophy in Animal and Food Science emphasis in Nutrition and Food Technology

Janet Tou, $\mathrm{PhD}$, Chair

Vagner Benedito, $\mathrm{PhD}$

Joseph Gigliotti, $\mathrm{PhD}$

Kristen Matak PhD

Division of Animal and Nutritional Sciences

Morgantown, WV

2020

Keywords: silver carp, protein powder, food safety, functional food, inflammation Copyright 2020 Derek C. Warren 


\begin{abstract}
Assessment of Protein Quality, Lipid Metabolism, Hepatic Transcriptome and Safety of a Silver Carp (Hypophthalmichthys molitrix) Derived Sarcoplasmic Protein Powder.
\end{abstract}

\title{
Derek C. Warren
}

Fishery resources are currently operating either near optimal yield or at levels with elevated risk for fish stock depletion. A solution for overcoming limitations of natural fish resources is through utilization of less desirable fish species and fish processing by-products. Water-soluble sarcoplasm proteins consist of $25-30 \%$ of protein in carp, are lost in wash water during processing and can be recovered and freezedried to produce a protein-rich powder (CSP). However, protein quality and safety of CSP must be evaluated prior to commercial use. High quality proteins are sought after in order to lower the amount of protein consumed for protein synthesis. Not only does this contribute to sustainability, but whey-based infant formulas with high protein content have been reported to increase body weight gain and risk of obesity at adulthood. However, low protein intake can risk protein-energy malnutrition characterized by fatty liver and hepatic dysfunction due to altered lipid metabolism.

The objective of this project was: 1) to evaluate the protein quality of CSP and effects of low (10\% kcal) protein diets on growth, body composition, renal and bone health, 2$)$ to assess low protein $(10 \% \mathrm{kcal})$ diets consisting of CSP or commercial milk proteins effects on lipid metabolism in liver and adipose tissue compared to a protein deficient diet, and 3) to investigate distinct phenotypic and hepatic transcriptome responses to low protein $(10 \% \mathrm{kcal})$ diets consisting of CSP, casein, and whey protein using a growing animal model. Young (age 28 days) female Sprague-Dawley rats were randomly assigned ( $n=8$ rats/group) to standard purified diets consisting of $10 \%$ protein as CSP, casein, whey protein or a protein-free diet.

Results showed greater $(\mathrm{p}<0.05)$ fecal amino acid excretion in casein-fed rats, but no significant differences in liver and muscle amino acid profiles among protein diets. All low protein diets supported growth within the normal range, but whey protein-fed rats had greater $(\mathrm{p}<0.05)$ adiposity. CSP, whey and casein-fed rats showed no differences in serum renal biomarkers or bone indices. In the liver, rats fed protein-free diet had the highest $(\mathrm{p}<0.05)$ total hepatic lipid content and highest histological evidence of hepatocyte fat infiltration. Rats consuming CSP showed no differences in hepatic weight, fat infiltration, and lipid metabolism biomarkers compared to casein and whey-fed rats. There was no effect of CSP on inflammation; however, pro-inflammatory cyclooxygenase- 2 was upregulated $(p<0.05)$ in adipose tissue of casein-fed rats which was balanced by upregulation of anti-inflammatory interleukin-10 response. Further, hepatic lipoprotein lipase was upregulated $(\mathrm{p}<0.05)$ in rats consuming casein in response to cytokine production. RNA sequencing of hepatic tissue was performed to further investigate.

Consumption of protein-free diet resulted in the greatest number $(1,814)$ of differentially expressed genes compared to casein diet. Abundance of IGF-1 transcripts were greater $(\mathrm{p}<0.05)$ in CSP and whey protein-fed rats. IGF-1 has been shown to illicit anabolic metabolism increasing the propensity for greater adiposity that was observed in whey-fed rats.

Collectively, results indicate protein quality of CSP is comparable to casein. Based on studies investigating kidney and bone health and detailed studies on hepatic lipid metabolism and gene expression, providing low protein diets consisting of CSP as the protein source is a physiologically safe option and may be preferable to whey protein for preventing increased adiposity. Further, recovery of CSP from an invasive fish species could be marketed as a sustainable alternative to current commercial protein powders. 


\section{Acknowledgements}

Finally, I have a deep appreciation to my family for encouraging me to continue my education. I would not be where I am today without them, and this project would not have been completed without your support and guidance.

I would like to thank my advisor, Dr. Janet C Tou for her guidance. I could not have done this without her support and our weekly meetings and numerous panicked phone conversations.

Thank you to my committee members; Dr. Vagner Benedito, Dr. Joseph Gigliotti, and Dr. Kristen Matak. They always had an open office door or inbox for when I had questions of which there were many. Further, I would like to thank the faculty and staff in the Animal and Nutritional Sciences Department at West Virginia University for their continuous support. A special thank you to Dr. Kimberly Barnes and Susan Slider for their guidance, training, and support in completing this project. I would not have made it this far without Dr. Barnes undergraduate mentorship, and I appreciate the hours Susie spent assisting me in the laboratory or just chatting when I needed a mental break.

This project was funded by Agriculture and Food Research Initiative Competitive Grant no. 2015-67017-23084 from the USDA National Institute of Food and Agriculture. 


\section{TABLE OF CONTENTS}

ABSTRACT

ACKNOWLEDGEMENTS

LIST OF TABLES $\quad$ vi

LIST OF FIRGURES $\quad$ viii

CHAPTER I 1

INTRODUCTION 1

REFERENCES 4

\begin{tabular}{ll} 
CHAPTER II & 7 \\
\hline
\end{tabular}

$\begin{array}{ll}\text { LITERATURE REVIEW } & 7\end{array}$

$\begin{array}{ll}\text { Introduction } & 7\end{array}$

Aquatic Protein Nutritional Quality $\quad 8$

Proteins and Renal Health 12

Proteins and Bone Health $\quad 15$

Non-Alcoholic Fatty Liver Disease 16

$\begin{array}{ll}\text { Inflammation Markers } & 18\end{array}$

$\begin{array}{ll}\text { Infant Nutrition and Protein } & 20\end{array}$

Branched Chain Amino Acid Catabolism $\quad 21$

IGF-1: Role and Signaling $\quad 22$

Protein Source Effect on Hepatic Transcriptome $\quad 23$

$\begin{array}{ll}\text { REFERENCES } & 26\end{array}$

\begin{tabular}{ll} 
CHAPTER III & 38 \\
\hline
\end{tabular}

$\begin{array}{ll}\text { STUDY OBJECTIVES AND HYPOTHESES } & 38\end{array}$

\begin{tabular}{lr} 
CHAPTER IV & 39 \\
\hline
\end{tabular}

$\begin{array}{ll}\text { INTRODUCTION } & 41\end{array}$

MATERIALS AND METHODS 43

$\begin{array}{ll}\text { RESULTS AND DISCUSSION } & 49\end{array}$

$\begin{array}{ll}\text { CONCLUSION } & 56\end{array}$ 
$\begin{array}{lc}\text { REFERENCES } & \mathbf{5 8}\end{array}$

\begin{tabular}{ll} 
CHAPTER V & $\mathbf{7 4}$ \\
\hline
\end{tabular}

$\begin{array}{ll}\text { INTRODUCTION } & \mathbf{7 6}\end{array}$

$\begin{array}{ll}\text { MATERIALS AND METHODS } & \mathbf{7 8}\end{array}$

$\begin{array}{ll}\text { RESULTS } & 83\end{array}$

$\begin{array}{ll}\text { DISCUSSION } & 86\end{array}$

$\begin{array}{ll}\text { CONCLUSION } & 92\end{array}$

$\begin{array}{ll}\text { REFERENCES } & 93\end{array}$

\begin{tabular}{lr} 
CHAPTER VI & 112 \\
\hline
\end{tabular}

$\begin{array}{ll}\text { INTRODUCTION } & 115\end{array}$

MATERIALS AND METHODS $\quad 116$

$\begin{array}{lr}\text { RESULTS } & 119\end{array}$

$\begin{array}{lr}\text { DISCUSSION } & 120\end{array}$

$\begin{array}{ll}\text { CONCLUSION } & 123\end{array}$

$\begin{array}{ll}\text { REFERENCES } & 125\end{array}$

\begin{tabular}{lr} 
CHAPTER VII & 138 \\
\hline
\end{tabular}

$\begin{array}{ll}\text { SUMMARY AND FUTURE DIRECTIONS } & 138\end{array}$ 
CHAPTER III

\section{LIST OF TABLES}

Table 1: Amino acid and nutritional composition of different protein sources and ingredient formulation of experimental protein diets.

Table 2: Protein quality and growth of female rats fed $10 \%$ protein diets consisting of casein, whey protein isolate, carp sarcoplasmic protein, or 2 weeks on $10 \%$ casein diet followed by a noprotein diet.

Table 3: Fecal, hepatic, and skeletal muscle amino acid profile of female rats fed $10 \%$ protein diets consisting of carp sarcoplasmic protein, casein, whey protein isolate, or 2 weeks on $10 \%$ casein diet followed by a no-protein diet.

68

Table 4: Body composition of female rats fed $10 \%$ protein diets consisting of carp sarcoplasmic protein, casein, whey protein isolate, or 2 weeks on $10 \%$ casein diet followed by a no-protein diet.

Table 5: Measurements of kidney and bone health in female rats fed $10 \%$ protein diets consisting of carp sarcoplasmic protein, casein, whey protein isolate, or 2 weeks on $10 \%$ casein diet followed by a no-protein diet.

Supplemental Table 1: Body composition corrected for body weight of female rats fed $10 \%$ protein diets consisting of casein, whey protein isolate, carp sarcoplasmic protein, or 2 weeks on $10 \%$ casein diet followed by a no-protein diet.

73

\section{CHAPTER IV}

Table 1: List of primers used for RT-qPCR analysis.

Table 2: Composition of rodent diets substituted with $10 \% \mathrm{kcal}$ protein of carp sarcoplasmic protein, casein or whey fed to growing female rats.

Table 3: Fatty acid analysis of rodent diets substituted with $10 \%$ kcal protein of carp sarcoplasmic protein, casein or whey.

Table 4: Effect of the consumption of different diets substituted with $10 \%$ kcal protein of carp sarcoplasmic protein, casein or whey for four weeks on growth parameters of growing female rats.

Table 5: Effect of the consumption of different diets substituted with $10 \%$ kcal protein of carp sarcoplasmic protein, casein or whey for four weeks on hepatic fatty acid composition and total lipid content. 
Table 6: Effect of consumption of different diets substituted with $10 \%$ kcal protein of carp sarcoplasmic protein, casein or whey for four weeks by growing female rats on hepatic lipid metabolism gene expression.

108

Table 7: Effect of the consumption of different diets substituted with $10 \%$ kcal protein of carp sarcoplasmic protein, casein or whey for four weeks on gonadal adipose tissue fatty acid composition and total lipid content.

Table 8: Effect of consumption of different diets substituted with $10 \%$ kcal protein of carp sarcoplasmic protein, casein or whey for four weeks by growing female rats on lipid metabolism gene expression in gonadal adipose tissue.

Table 9: Effect of the consumption of different diets substituted with $10 \%$ kcal protein of carp sarcoplasmic protein, casein or whey for four weeks on serum measurements of liver function enzymes, cholesterol, and triglycerides.

\section{CHAPTER V}

Table 1: Nutritional level and ingredient composition of experimental protein diets.

Table 2: Amino analysis of carp sarcoplasmic protein, casein, and whey protein powders 129

Table 3: Effect of the consumption of different diets substituted with $10 \%$ kcal protein of carp sarcoplasmic protein, casein or whey for four weeks on growth parameters of growing female rats.

Table 4: Statistics of transcript expression

Supplemental Table 1: Hepatic fatty acid composition and total lipid content after consuming diets substituted with $10 \% \mathrm{kcal}$ protein of CSP, casein or whey protein for four weeks. 
CHAPTER II

\section{LIST OF FIGURES}

Figure 1: Diagram of de novo lipogenesis, lipid storage, and transport pathway.

Figure 2: Catabolism pathway for branched chain amino acid.

Figure 3: Illustration of Branched Chain Amino Acids and IGF-1 role in the activation of mTORC1 and subsequent downstream pathways.

\section{CHAPTER III}

Figure 1: Body weights of female rats fed $10 \%$ protein diets consisting of carp sarcoplasmic protein, casein, whey protein isolate, or 2 weeks on $10 \%$ casein diet followed by a no-protein diet.

\section{CHAPTER IV}

Figure 1: Body weights of female rats fed $10 \%$ protein diets consisting of carp sarcoplasmic protein, casein, whey protein isolate, or 2 weeks on $10 \%$ casein diet followed by a no-protein diet.

Figure 2: Representative histological staining images of the liver of growing female rats fed different proteins or no-protein diets.

\section{CHAPTER V}

Figure 1: Body weights of female rats fed $10 \%$ protein diets consisting of carp sarcoplasmic protein, casein, whey protein isolate, or 2 weeks on $10 \%$ casein diet followed by a no-protein diet.

Figure 2: Hierarchical cluster analysis of expressed genes in rats fed $10 \% \mathrm{kcal}$ protein diets of carp sarcoplasmic protein (CSP), casein, or whey and no protein (NP) diets for 4 weeks.

Figure 3: Comparison pathway analysis of differentially expressed genes in rats fed carp sarcoplasmic protein (CSP), whey or no protein diets compared to rats fed casein as a control.

Figure 4: Effect of the consumption of different diets substituted with 10\% kcal protein of carp sarcoplasmic protein, casein or whey for four weeks on hepatic transcript abundance of genes involved in branch chain amino acid metabolism.

Figure 5: Effect of the consumption of different diets substituted with $10 \%$ kcal protein of carp sarcoplasmic protein, casein or whey for four weeks on hepatic transcript abundance of genes involved in the IGF-1 signaling pathway.

144 


\section{Chapter I \\ Introduction}

As of 2016, the Fishes and Aquaculture Organization (FAO) reported global aquaculture growth declined by $3.3 \%$ meanwhile the human population continues to increase by $1.6 \%$, annually, with an expected global population of $\sim 10$ billion by 2050 . Currently, fishery resources are operating either near optimal yield or at levels with elevated risk for fish stock depletion (FAO, 2016). A solution for overcoming limitations of natural fish resources is through utilization of less desirable fish species and nutrient dense fish processing by-products.

Silver carp (Hypophthalmichthys molitrix) was imported to the United States in the 1970s for use as filter feeders in aquaculture. Since their unintentional introduction into the wild, silver carp are an invasive species causing decimation of freshwater ecosystems by out competing native fish species for phytoplankton. This resulted in negative impacts on the food chain in North American freshwater river systems (Chick, 2001). Yet, carp is composed of $7.13 \%$ fat, consisting mainly of the health beneficial long-chain omega-3 polyunsaturated fatty acids ( $\mathrm{n}-3$ PUFAs) (Ljubojević et al., 2017), and 16.69\% protein, comprising all the essential amino acids required by adults and children (Skibniewska, 2013). Silver carp's abundance and nutritional composition makes it a sustainable fish species.

Previous research reported that silver carp sarcoplasmic proteins solubilized in wash water can be recovered and freeze-dried into a protein-rich powder (Warren et al., 2018). However, the protein quality and safety of this novel protein supplement needs to be evaluated before CSP can be commercialized. Wibowo and colleagues (2007) compared sarcoplasm protein powder recovered by chitosan-alginate precipitation from surimi wash water to casein and commercial protein meals. Water soluble protein recovered from surimi wash water was determined to be 
higher in protein quality than casein and commercial protein meals. Additionally, the recovered protein was considered safe based on an absence of significant changes in blood chemistry measurements after feeding $18 \% \mathrm{kcal}$ protein to male rats aged 40 days for 20 days during the pubescent stage. In our study, reduced protein $(10 \% \mathrm{kcal})$ diets and female rats were used to investigate whether lower protein content may reduce the risk of obesity and renal damage. However, low protein diets may be inadequate during the growth stage.

Protein-energy malnutrition is defined as an imbalance between protein and energy intake and the amount required for optimal growth, development, and function (Fock et al., 2010; Bossola, 2015). Protein-energy malnutrition has been reported to alter liver histology and biochemical characteristics ultimately, leading to fatty liver and hepatic dysfunction (Caballero et al., 2015; Feres et al., 2010, Zutphen et al., 2016). When dietary protein content is reduced protein quality and digestibility becomes more important for sustaining growth and metabolic function. Koletzko and others (2009) found infants fed diets with lower inclusion of higher quality proteins reduced the risk of later in life obesity development. However, infant formulas often have higher protein content compared to human milk and have been related to weight gain and obesity later-in-life (Tang, 2018). Further, a European multi-centered clinical study reported infants receiving a high protein formula had a greater kidney volume compared to infants receiving a low protein formula or breastfed infants. Higher kidney volume was attributed to increased renal workload indicated by greater serum urea/creatinine ratios (Escribano et al., 2011).

Ong and others (2009) reported greater body weight gains in formula-fed infants compared to infants fed human milk due to increased insulin like growth factor 1 (IGF-1) and insulin excretion. Hepatic secretion of IGF-1 is dependent on nutritional status and hormones such as 
insulin (Daughaday and Rotwin, 1989). Diets low in protein have been shown to decrease plasma concentrations of IGF-1 in growing pigs (Deng et al., 2007). While dietary branch chain amino acids (e.g. leucine, isoleucine, valine) have been reported to induce IGF-1 excretion. Wang et al. (2017) reported greater expression of IGF-1 from amino acid supplementation because of an interaction between mammalian target of rapamycin (mTOR), an important intracellular sensor for cell growth and autophagy, and peroxisome proliferator-activated receptor gamma (PPAR $\gamma$ ), a transcription factor involved in the regulation of lipolysis. Song and others (2016) reported supplementation of protein sources from beef, chicken, pork and carp in the recommended amount (18\% by weight) for seven days resulted in distinct gene expression and physiological responses. Carp protein consumption was shown to down-regulate genes regulating fatty acid oxidation and the synthesis of bile acids, triglycerides, and cholesterol with other proteins altering insulin secretion.

Therefore, the objectives of this research project were:

1) To evaluate the protein quality of CSP and effects of lower (10\% kcal) protein diets on growth, body composition, renal markers, and bone health in a rat model.

2) To assess low protein $(10 \% \mathrm{kcal})$ diets from CSP and two common commercial protein powders (casein and whey protein) effects on lipid metabolism in hepatic and adipose tissue compared to a protein-energy malnutrition diet.

3) To investigate distinct phenotypic and hepatic transcriptome responses due to low protein (10\% kcal) diets supplemented with CSP and milk proteins, casein and whey, in a growing animal model. 


\section{References:}

1. Bossola M. (2015) Nutritional interventions in head and neck cancer patients undergoing chemoradiotherapy: a narrative review. Nutrients, 7, 265-76.

2. Caballero V., Mendieta J., Lombardo D., Saceda M., Ferragut J., Conde R., et al. (2015). Liver damage and caspase-dependent apoptosis is related to protein malnutrition in mice: effect of methionine. Acta Histochem, 2015, 117, 126-35.

3. Chick, J. H. (2001). Invasive Carp in the Mississippi River Basin. Science. 292, 22502251. http://doi:10.1126/science.292.5525.2250.

4. Deng D, Li AK, Chu WY, Huang RL, Li TJ, Kong XF, et al. (2007). Growth performance and metabolic responses in barrows fed low-protein diets supplemented with essential amino acids. Livest Sci., 2007, 109(1-3), 224-227.

5. Escribano, J., Luque, V., Ferre, N., Zaragoza-Jordana, M., Grote, V., Koletzko, J., Gruszfeld, D., Socha, P., Dain, A., Van Hees, J., Verduci, E., Closa-Monasterolo, R. (2011). Increased Protein Intake Augments Kidney Volume and Function in Healthy Infants. Kidney International. 79, 783-790. http://doi:10.1038/ki.2010.499.

6. Daughaday WH, Rotwein P. Insulin-like growth factors I and II. Peptide, messenger ribonucleic acid and gene structures, serum, and tissue concentrations. Endocr Rev. 1989; 10(1), 68-91. Epub 1989/02/01. doi: 10.1210/edrv-10-1-68

7. FAO, Food and Agriculture Organization of the United Nations. (2016). The State of World Fisheries and Aquaculture, 2016

8. Feres N., Reis S., Veloso R., Arantes V., Souza L., Carneiro E., et al. (2010). Soybean diet alters the insulin-signaling pathway in the liver of rats recovering from early-life malnutrition. Nutrition, 26, 441-8. 
9. Fock R., Rogero M., Vinolo M., Curi R., Borges M., Borelli P. (2010). Effects of protein-energy malnutrition on NF-kappaB signalling in murine peritoneal macrophages. Inflammation, 33, 101-9.

10. Koletzko, B, von Kries, R, Closa, R., Escribano, J, Scaglioni, S, Giovannini, M, Beyer, J, Demmelmair, H, Gruszfeld, D, Dobrzanska, A, Sengier, A, Langhendries, J, P, Rolland Cachera M, F, Grote, V. (2009). Lower Protein in Infant Formula is Associated with Lower Weight up to age 2 y: a Randomized Clinical Trial. American Journal of Clinical Nutrition, 89, 1836-1845. http://doi.org/10.3945/ajcn.2008.27091.

11. Ljubojević, D., Đorđević, V., \& Ćirković, M. (2017). Evaluation of Nutritive Quality of Common Carp, Cyprinus carpio L. IOP Conference Series: Earth and Environmental Science, 85, 012013. http://doi.org/10.1088/1755-1315/85/1/012013.

12. Ong, K., Langkamp, M., Ranke, M., Whitehead, K., Hughes, I., Acerini, C., Dunger. D. (2009). Insulin-like growth factor I concentrations in infancy predict differential gains in body length and adiposity: the Cambridge Baby Growth Study. The American Journal of Clinical Nutrition, 90(1), 156-161, https://doi.org/10.3945/ajcn.2008.27408

13. Skibniewska, K., Zakrzewski, J., Kłobukowski, J., Białowiąs, H., Mickowska, B., Guziur, J., Walczak, Z., Szarek, J. (2013). Nutritional Value of the Protein of Consumer Carp Cyprinus carpio L. Czech Journal of Food Sciences, 31(4), 313-317. http://doi.org/10.17221/337/2012-cjfs.

14. Song, Shangxin \& Hooiveld, Guido \& Li, Mengjie \& Zhao, Fan \& Zhang, Wei \& Xu, Xing-Lian \& Muller, Michael \& Li, Chunbao \& Zhou, G.H.. (2016). Distinct physiological, plasma amino acid and liver transcriptome responses to purified dietary 
beef, chicken, fish, and pork proteins in young rats. Molecular Nutrition \& Food Research. 60. 1199-1205. https://doi.org/10.1002/mnfr.201500789.

15. Tang M. (2018). Protein Intake during the First Two Years of Life and Its Association with Growth and Risk of Overweight. International Journal of Environmental Research \& Public Health. 15(8), E1742. http://doi.org/10.3390/ijerph15081742.

16. Wang, Songbo \& Zhuang, Lu \& Xing, Kongping \& Zhang, Mengyuan \& Zhu, Xiaotong \& Wang, Lina \& Gao, Ping \& Xi, Qianyun \& Jiajie, Sun \& Zhang, Yong-Liang \& Li, Tiejun \& Shu, Gang \& Jiang, Qingyan. (2017). Dietary protein-induced hepatic IGF-1 secretion mediated by PPAR $\gamma$ activation. PLOS ONE. 12. e0173174. 10.1371/journal.pone.0173174.

17. Warren, D., Paker, I., Jaczynski, J., \& Matak, K. E. (2018). Nutritional Quality and Physical Characteristics of Soluble Proteins Recovered from Silver Carp. Journal of Food Science, 83(7), 1970-1979. http://doi.org/10.1111/1750-3841.14170.

18. Wibowo, S., Savant, V., Cherian, G., Savage, T. F., Velazquez, G., \& Torres, J. A. (2007). A Feeding Study to Assess Nutritional Quality and Safety of Surimi Wash Water Proteins Recovered by a Chitosan-Alginate Complex. Journal of Food Science, 72(3). http://doi.org/10.1111/j.1750-3841.2007.00291.x.

19. Zutphen, T., Ciapaite, J., Bloks, V., Ackereley, C., Gerding, A., Jurdzinski, A., et al. (2016). Malnutrition-Associated Liver Steatosis and ATP Depletion is caused by Peroxisomal and Mitochondrial Dysfunction. Journal of Hepatology, 65(6), 1198-1208. http://doi.org/10.1016/j.jhep.2016.05.04 


\section{Chapter II \\ Literature Review}

\section{Literature Review}

\section{Introduction}

As of 2016, global fisheries have been operating close to maximal levels risking depleting fish stock (FAO, 2016). According to the Fishes and Aquaculture Organization, expansion of aquaculture industries has decreased by 3.3 percent while the global population is expected to reach 10 billion by 2050 (FAO, 2016). Natural resources, such as fish stock, have innate limitations. However, solutions can be developed to overcome these innate limitations such as redirecting fish processing by-products or by using a less desirable fish species.

Silver carp (Hypophthalmichthys molitrix) was initially brought into the United States during the 1970 s as an algal control measure in aquaculture and sewage treatment ponds. Flooding in the 1980s resulted in the introduction of silver carp to the Mississippi River. Since their unintended introduction, silver carp have been reported in many rivers, lakes, and tributaries of the Mississippi River (Chick 2001). Due to a lack of natural predators in United States waterways, silver carp continue to spread into other habitats, severely disrupting existing ecosystems (Chick 2001). Despite their abundance, silver carp are underutilized due to their boniness that makes consumption and fish processing difficult. A proposed solution to the problem of overabundance of this invasive fish species is to use silver carp as a protein source for human consumption.

Silver carp contain all 10 essential amino acids in quantities that are ideal for human needs (Ljubojević 2017). The protein and lipid composition of wild carp are $16.69 \%$ and $7.13 \%$, respectively. Further, $72.64 \%$ of fatty acids consist of polyunsaturated fatty acids (PUFAs) with the health-beneficial omega-3 PUFAs ( $\omega-3$ PUFAs) being particularly abundant at $5.97 \%$ 
(Ljubojević 2017). Previous research in our laboratory investigated the recovery, drying, and in vitro characteristics of a protein-rich silver carp sarcoplasmic protein powder; however, in vivo quality and safety was not considered (Warren et al. 2018).

The purpose of this literature review is to provide an overview of the limited published studies that have investigated nutritional quality of aquatic proteins compared to other commercial sources. Additionally, studies focused on safety of low protein diets will be reviewed due to the initiative to reduce the protein content of infant formulas to prevent childhood obesity without causing protein energy malnutrition that can result in in stunted growth and NAFLD.

\section{Aquatic Protein Nutritional Quality}

The nutritional value of protein-peptide hydrolysate $(\mathrm{PPH})$ material derived from hairtail fish was evaluated in a study by Ding and colleagues (2016). Soluble proteins were extracted from imitated surimi wash water then freeze-dried. The proximate composition of the surimi wash water showed the wash-water contained $8.19 \pm 0.10 \mathrm{mg} / \mathrm{ml}$ dry matter, $0.54 \pm 0.01 \mathrm{mg} / \mathrm{ml}$ (6.5\%) lipid, and $6.68 \pm 0.04 \mathrm{mg} / \mathrm{ml}(81.5 \%)$ crude protein. Water soluble proteins $(2.26 \pm 0.01$ $\mathrm{mg} / \mathrm{ml}$ ) were mainly composed of sarcoplasmic proteins. Flavoring compounds (aldehydes, ketones, alcohols, hydrocarbons, and heterocyclic compounds), oligopeptides and free amino acids, were the main components of the non-protein nitrogen $(1.92 \pm 0.01 \mathrm{mg} / \mathrm{ml})$. There were no differences in crude protein concentration and dry matter between the initial surimi wash water $(6.78 \pm 0.04)$ and recovered PPH $(6.74 \pm 0.06 \mathrm{mg} / \mathrm{ml})$. The composition of water-soluble proteins and nonprotein nitrogen for PPH was $2.81 \pm 0.051$ and $3.94 \pm 0.064 \mathrm{mg} / \mathrm{ml}$. This was higher than the water-soluble protein $(2.26 \pm 0.009 \mathrm{mg} / \mathrm{ml})$ and non-protein nitrogen $(1.92 \pm 0.01$ 
$\mathrm{mg} / \mathrm{ml}$ ) identified in the surimi wash water. This was attributed to the degradation of fish particles during hydrolysis.

The recovered PPH contained all the essential amino acids needed by humans, which accounted for $44.1 \%$ of total amino acids with total amino acid accounting for $78.2 \%$ of the dry matter. High levels of nonessential amino acids were also detected in the recovered proteinpeptide material. The FAO/WHO essential amino acid requirements and comparison to whole egg protein were used to determine nutritional value. The amino acid score for the recovered $\mathrm{PPH}$ was greater than the FAO/WHO essential amino acid requirements. Methionine + cysteine was the first limiting amino acid. An essential amino acid index of 101.7 (>95), indicated that the recovered protein-peptide material has comparable nutritional value to standard whole egg protein. The biological value (BV) of the recovered PPH (BV 76.7) was greater than that of wheat (BV 67), peanuts (BV 59), and pork (BV 74) with beef (BV 76). Collectively, study results indicated that recovered PPH extracted from wash water possesses a high nutritional value (Ding et al., 2016). However, these protein quality calculations did not take the bioavailability of recovered proteins into account.

Wibowo and others (2007) determine the safety and nutritional value of the recovered surimi wash water protein. Surimi wash water was collected, solids removed, and then treated with Chitosan-Alginate (Chi-Alg) to coagulate the soluble proteins in the wash water. Proximate composition and amino acid analysis were conducted on the freeze-dried recovered surimi wash water protein and compared to commercial protein meal sources. Proximate composition showed freeze-dried recovered protein had the higher crude protein content of $73.1 \pm 1.67 \%(68.93 \%$ on wet basis) compared to herring, menhaden, soybean, and corn gluten meals, with $66.50 \%$, $58.86 \%, 43.21 \%$ and $62.45 \%$ protein on a wet basis, respectively. 
Among the fish-based commercial protein meals, recovered surimi wash water protein had higher carbohydrate content $(3.39 \%)$ compared to 1.3 and $2.9 \%$ reported in the herring and menhaden feeds, respectively. Lipid content in surimi wash water was $8.11 \%$ compared to herring and menhaden fish protein meals with 8.0 and $7.8 \%$ lipid, respectively. Surimi wash water protein had higher lipid content compared to soybean $(3.1 \%)$ and corn gluten $(1.7 \%)$ meals. Total reported essential amino acid for the surimi wash water protein and four protein meals were $51.8 \%, 35.4 \%$ (herring), $41.4 \%$ (menhaden), $25.4 \%$ (soybean), and $42.8 \%$ (corn gluten), repressively. The amino acid profile showed surimi wash water contained greater concentrations of all measured essential amino acids compared to herring, menhaden, soybean, and corn gluten commercial meal sources. The tryptophan content for surimi wash water protein and commercially available meals were not reported. Collectively, results indicated surimi wash water protein was nutrient rich and comparable to commercially available feed-protein sources, in terms of crude protein composition and essential amino acid content (Wibowo et al., 2007).

Another study investigated recovery of protein from a novel source not using the Chi-Alg method. Protein was recovered from whole krill using isoelectric solubilization-precipitation producing a protein concentrate (Gigliotti et al., 2008). Krill (a species of pelagic crustaceans) are estimated to consist of the largest multi-cellular aquatic biomasses. Typically, krill consist of $60-80 \%$ protein, $7-26 \%$ lipid, and $12-17 \%$ ash on a dry basis. Isoelectric solubilization precipitation recovered approximately $46 \%$ of protein from krill producing a protein concentrate composed of $77.7 \%$ protein, $8.1 \%$ lipid, and $4.4 \%$ ash (on a dry basis). The FAO/WHO/UNU amino acid requirements were used to compare the amino acids profile to human adult and infant requirements. All nine essential amino acids were present in sufficient amounts to meet the FAO/WHO/UNU amino acid requirements. Additionally, the krill protein concentrate contained 
greater $(\mathrm{p}<0.05)$ amounts of protein and total essential amino acids compared to whole krill at $531.5 \mathrm{mg} / \mathrm{g}$ and $212.1 \mathrm{mg} / \mathrm{g}$, respectfully.

Following amino acid evaluation of recovered protein, diets containing $10 \%$ krill protein concentrate or casein were fed to growing (age $28 \mathrm{~d}$ ) female rats to characterize in vivo bioavailability and protein quality. No differences were found in body weight among the protein groups following four weeks of feeding. Results indicated krill protein concentrate was a complete protein comparable in quality to casein. No significant differences were reported among the protein quality measurements: true digestibility, biological value, net protein utilization, protein digestibility corrected amino acid score, and protein efficiency ratio. Collectively, results showed similar protein quality for krill protein concentrate and casein (Gigliotti et al., 2008).

Previous research in our laboratory investigated the effect of separation temperature on in vitro nutritional quality of a soluble protein derived from silver carp (Warren et al., 2018). Water soluble proteins were recovered from homogenized silver carp using dilution, homogenization, and centrifugation. The recovered protein wash water was freeze-dried and powdered for analysis. The recovered silver carp sarcoplasmic protein powder (CSP) contained approximately $82 \%$ protein, $4 \%$ lipid and $15 \%$ ash. The high mineral content was due to minerals commonly stored in bone and cartilage being release during homogenization.

Fatty acid profiling showed CSP contained mainly saturated fatty acids (31\%) and monounsaturated fatty acids $(27 \%)$ with polyunsaturated fatty acids composing $13 \%$ of total lipids. The amino acid profile of the CSP was compared to the FAO/WHO/UNU adult and infant amino acid requirement. CSP met all amino acid requirements for adults; however, amino acid requirements set for infants were not met due to low contents of some branched chain amino 
acids (isoleucine and leucine) and sulfur amino acids (cysteine and methionine). Warren et al. (2018) suggested proteins derived from silver carp could be a nutritious source of amino acids and micronutrients. However, these data do not consider safety or bioavailability of the protein powder. Collectively, results of these studies indicate protein derived from aquatic sources are nutritious; however, bioavailability and safety also need to be addressed.

\section{Proteins and Renal Health}

For approval of commercial use, the safety of novel protein supplements must be evaluated. Studies have found an association between protein consumption and the development of renal disease (Friedman, 2004). Consumption of chronic and acute high protein diets showed an increase in glomerular filtrations rates and renal blood flow, increasing risk of kidney stress and potential for renal damage (Martin et al., 2005). In the clinical setting, individuals diagnosed with renal disease are advised to follow a standard dietary recommendation is to restrict the consumption of proteins (Martin et al., 2005). A study consisting of participants with no prior history of kidney disease found estimated glomerular filtration rate $(e G F R)$ increased $(p<0.05)$ in participants consuming a diet in which $10 \%$ of kilocalories from carbohydrates were replaced by protein (referred to as a protein emphasized diet). The eGFR scores were higher in participants consuming the protein emphasized diet as compared to diets with elevated carbohydrate and unsaturated fat diets. Due to potential health risks to participants, the study was discontinued and therefore, unable to analyze the effects of long-term, high protein diets (Juraschek et al., 2013).

The effects of a high and low protein intake on kidney health was investigated in a European multi-centered clinical study. Participants consisted of formula-fed infants $(n=601)$ enrolled in a 1-year long program and randomly assigned to either a low-protein $(1.94 \pm 0.46 \mathrm{~g} / \mathrm{kg})$ or highprotein $(3.0 \pm 0.7 \mathrm{~g} / \mathrm{kg}$ per day) formula (Escribano et al., 2011). Results indicated infants 
receiving the high protein formula had greater $(\mathrm{p}<0.05)$ kidney volumes, serum urea, and urea to creatinine ratios compared to infants receiving a low protein formula or breastmilk. Higher kidney volume was attributed to the increased renal workload indicated by greater serum urea/creatinine ratios. There were no differences were found among infants fed the low-protein formula compared to breast-fed infants (Escribano et al., 2011). Due to ethical consideration in conducting studies using infant and growing children, studies have mainly evaluated consumption of proteins from different sources on renal health using animal models.

Diet-induced nephrocalcinosis is a common occurrence in female rats (Rao, 2002). The transition of nephrocalcinosis to nephrolithiasis was implicated in nephropathy and subsequent renal failure in rats (Jara et al., 2004). Gigliotti et al. (2008) compared feeding a low protein $(10 \% \mathrm{kcal})$ diets consisting of krill protein concentrate and casein to growing female rats. Rats fed krill protein concentrate consumption had lower $(\mathrm{p}<0.05)$ kidney weights compared to casein. Additionally, total renal mineral content was lower $(\mathrm{p}<0.001)$ in rats fed krill protein concentrate $(0.07 \mathrm{~g} / \mathrm{g}$ kidney $)$ compared to rats fed casein $(0.3 \mathrm{~g} / \mathrm{g}$ kidney). The study results suggested feeding different protein sources influenced mineral deposition in the kidney with krill protein concentration reducing renal calcification. Gigliotti et al. (2010), further investigated the pathogenesis of renal mineralization and renal calcium deposition in casein fed rats found krill protein concentrate prevented early renal injury by modulating urinary n-acetyl glucosaminidase activity, renal mineralization, and proteinuria while improving glomerular filtration rates. In addition to protein, other bioactive nutrients in the krill protein concentrate, $\omega$-3 PUFAs, also appeared to have renal protective effects. Collectively, the studies by Gigliotti and colleagues $(2008 ; 2010)$ provided evidence that low protein diet consisting of aquatic sourced proteins attenuated diet-induced renal injury and improved function. 
Zhang and Beynan (1992) supplemented growing female rats protein diets sourced from soybean, casein, or cod meal at doses consisting of $2.40,4.79$ or $7.19 \mathrm{~g}$ nitrogen/100 $\mathrm{g}$ for 3 weeks. Lower kidney calcium concentrations $(\mathrm{p}<0.05)$ were found in rats fed cod meal compared to soybean and casein-fed rats. Furthermore, evidence of nephrocalcinosis was absent when renal histology was examined indicating consumption of cod meal had minimal effects of renal health.

Wibowo et al. (2007) compared sarcoplasmic protein powder recovered by chitosan-alginate precipitation from surimi wash water to casein and commercial protein meals. While protein recovered from surimi wash water was determined to be higher in protein quality than casein and commercial protein meals, residual chitosan has been associated with safety issues such as enlargement of the kidneys. Consumption of surimi wash water extracted with chitosan resulted in greater $(\mathrm{p}<0.05)$ final kidney weights compared to the standard casein and casein-chitosan diets group of $1.4 \mathrm{~g}, 1.2 \mathrm{~g}$ and $1.2 \mathrm{~g}$, respectfully. Although renal histology and mineral content was not quantified; there were no significant differences in blood biomarkers kidney functions. These results support the safety of surimi wash water protein recovered using chitosan-alginate precipitation (Wibowo et al., 2007). Collectively, studies provide support for safety and potentially protective effects of aquatic protein consumption on renal health. To the best of our knowledge, no studies have been conducted to determine the safety of carp derived sarcoplasmic protein recovered from wash water on renal health.

Another safety concern is kidney damage as it reduces the body's ability to buffer acids produced during protein metabolism. Particularly, sulfur amino acids may cause skeletal tissue to liberate its calcium stores which alters the structural rigidity of bone (Cuenca-Sanchez et al., 2015). Therefore, it is important to evaluate the effect of consuming protein from novel sources on bone health. 


\section{Protein and Bone Health}

Both high and low protein diets can be detrimental for bones. When high protein diets are consumed, the kidneys may be unable to neutralize the acid load produced in amino acid metabolism. In order to buffer increased acid load, bone release stored carbonate and calcium which can affect long-term bone health (Cuenca-Sanchez et al., 2015). Subsequently, release of calcium stores from bone and increased calcium excretion results in bone loss which increases the risk of osteoporosis (Cuenca-Sanchez et al., 2015).

Low protein diets may also be detrimental to bones. Kerstetter and colleagues (2003) reported low dietary protein intake correlated with reduced bone density and increased rates of bone loss. Further, reduced bone density and structure during the growth and development stage increases risk of osteoporosis in adulthood (Gordon et al., 2017).

Animal models have been used to evaluate novel protein sources. Rats fed $10 \%$ krill protein concentrate and casein showed no differences in bone morphometry and bone strength (Gigliotti et al., 2010). These results may be due to krill protein concentrate containing high concentrations of calcium and phosphorous. Calcium and phosphorous are critical for formation of hydroxyapatite which provide mechanical resistance of the organic bone matrix (Bonjour, 2011). Similarly, Fournier et al., (2014) fed low protein (5\% kcal casein) diets containing calcium $(0.2 \%)$ and phosphorous $(0.16 \%)$ to growing Sprague-Dawley female rats for eight weeks. Results indicated supplementation of calcium and phosphorous attenuated the reduction in bone mass and strength typically related to low protein diet consumption.

Dietary protein is metabolized to urea for excretion by the kidneys (Friedman, 2004) and therefore, high protein intakes may contribute to both kidney and liver injury and over the long 
term reduced function. Alternatively, protein energy malnutrition has been observed to cause fatty liver (Kumar et al.,1972).

\section{Non-Alcoholic Fatty Liver Disease}

Non-alcoholic fatty liver disease (NAFLD) is defined as steatosis of the liver that is not caused by alcohol consumption. NAFLD among of the most prevalent liver diseases in adults worldwide. Additionally, the prevalence of NAFLD in children is also increasing (Munteanu et al., 2016; Temple et al., 2016). NAFLD is diagnosed by light microscopic examination of hematoxylin and eosin stained liver sections (4-5 $\mu \mathrm{m}$ thick) showing fat vacuoles in $>5 \%$ of hepatocytes (Sanyal et al., 2011).

The dysregulation of hepatic lipid metabolism is illustrated in Figure 1 (Millar et al., 2013). Briefly, the mechanism in NAFLD may be due to enhance de novo lipogenesis (DNL) by nutrients stimulating transcription factors involved in the DNL pathway (Strable et al 2010; Naik et al., 2013). Fatty acid synthetase (FAS) is activated by transcription factor sterol regulatory binding protein-1c (SREBP-1c) and carbohydrate element response binding protein (ChREBP). FAS produces saturated fatty acids and stearoyl-CoA desaturase (SCD-1) removes hydrogens from saturated fatty acids producing monounsaturated fatty acids (MUFAs). De novo synthesized fatty acids are used for synthesis of triglycerides. The rate limiting enzyme in by de novo synthesis of triglycerides is diacylglycerol O-acyl transferase-2 (DGAT2). Endogenous triglycerides either remain in the liver, or following activation of microsomal triglyceride transport protein (MTTP) are transported to extrahepatic tissue in very-low density lipoprotein (VLDL). In the circulation, VLDL interact with lipoprotein lipase (LPL) in peripheral tissues such as adipose tissue. LPL removes triglycerides from VLDL to be used in energy production or for storage (Feingold et al., 2018). 
While the etiology of NAFLD is often associated with poor diets containing high amounts of saturated fatty acids and simple carbohydrates, dietary protein has also been shown to affect NAFLD. In 1972, Kumar et al. (1972) reported rhesus monkeys provided protein restricted diets developed fatty liver due to enhanced hepatic triglycerides and had reduced serum triglycerides and phospholipids. Results indicated protein deficient diets impair secretion of hepatic triglycerides as VLDLs. In the absence of dietary protein, de novo protein synthesis is inhibited. In turn, this decreases VLDL production and transport resulting in increased hepatic lipid accumulation (Kumar et al., 1972). In a more recent study, Zutphen et al. (2016) fed growing rats low protein $(5 \% \mathrm{kcal})$ diets to assess peroxisomal and mitochondrial dysfunction as a potential underlying mechanism in malnutrition induced NAFLD. Results showed hepatic steatosis and hypoalbuminemia was accompanied by reduced peroxisome number and mitochondria activity which impaired hepatic ATP production through oxidation of fatty acids (Zutphen et al., 2016). In contrast, high protein and low carbohydrate diets prevent hepatic fat deposition by stimulating carbohydrate metabolism, DNL, and lipid transport (Kargulewicz et al., 2014).

Duarte et al. (2014) reported providing high protein and low carbohydrate diets to adults with NAFLD reduced VLDL and low density lipoprotein (LDL) concentrations, enhanced high density lipoprotein (HDL), and improved liver damage biomarkers. Additionally, protein source has been shown to affect NAFLD progression. Kani et al. (2014) found providing NAFLD patients a low calorie and low carbohydrate diets containing soy protein improved biomarkers of liver damage, but lipid profiles were not affected. Similarly, soy protein supplementation reduced plasma cholesterol and hepatic triglyceride deposition while enhancing insulin sensitivity and antioxidant capacity in rats (Yang et al., 2011). 
Given the limited number of studies, additional research is needed to determine the role dietary protein amount and source on liver health and disease pathogenesis. This is important because untreated NAFLD can progress to non-alcoholic steatohepatitis (NASH) indicated by inflammation in as well as liver steatosis (Michelotti et al., 2013). It is estimated that 25\% of the world's population has NAFLD with a quarter of those individuals having NASH (Diehl et al., 2017). A multiple-hit model has been used to explain the progression of NAFLD, initiated by fat accumulation in the liver followed by the onset of inflammation (Buzzetti et al., 2016). The immune system is implicated in a variety of diseases, including those associated with poor diet. Therefore, we will also introduce the major inflammatory markers pertaining to diet-induced diseases.

\section{Inflammatory Markers}

Interleukin 10 (IL-10) and tumor necrosis factor alpha (TNF- $\alpha$ ) are often referred to as "the good" and "the ugly" cytokines, respectively (Stenvinkel et al., 2005). IL-10 is suggested to be the most important anti-inflammatory cytokine with secretion typically followed by a proinflammatory signal by a few hours (Stenvinkel et al., 2005). TNF- $\alpha$ is multifaceted with roles in lipid metabolism, coagulation, insulin resistance, and endothelial dysfunction. However, TNF- $\alpha$ is proposed to be the master regulator of cytokines (Stenvinkel et al., 2005). TNF- $\alpha$ and the transcription factor, nuclear factor kappa-light enhancer of activated B cells (NFkB), are key regulators in COX-2 expression. COX-2 catalyzes the conversion of arachidonic acid to proinflammatory prostaglandins that play a significant role to the pathology of several diseases (Lee at al., 2015; Lim et al., 2001).

NAFLD has been shown to stimulate inflammatory gene expression, through activation of

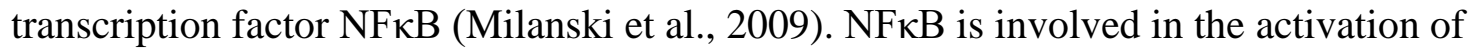


downstream inflammatory cytokines, such as interleukin 6 (IL-6) and TNF- $\alpha$, resulting in increased inflammation in the liver (Buzzetti et al., 2016; O’Neill et al., 1997). This inflammatory cascade is not limited to the liver. The inflammatory process was also implicated in adipose tissue. Lipogenesis resulting from alterations in fatty acid and glucose metabolism result in changes in fatty acid profiles of stored lipids in adipose tissue and inflammation status. This state can further exacerbate increased hepatic DNL in NAFLD patients (Musso et al., 2012; Burhans et al., 2016; Tamura et al 2015). When mitochondria and peroxisomes are overloaded by increased lipid production, lipid derived reactive oxygen species (ROS) are produced which activate inflammatory pathways (Buzzetti et al., 2016). Cusi (2009) reported ROS, together with oxidized lipoproteins, may activate Kupffer and hepatic stellate cells, which lead to additional inflammation and fibrosis. Further, increased generation of reactive oxygen species and inflammation from free fatty acid metabolism promotes NAFLD progression to more severe NASH (Michelotti et al., 2013).

The relationship between protein malnutrition and NAFLD has not been well-studied. Protein malnutrition has been shown to increase inflammatory reactivity that may contribute to development of NAFLD and edema (Sauerwein et al., 1997). Plasma concentrations of mediators of the inflammatory cascade were assessed in children identified with protein energy malnutrition. Children with protein energy malnutrition exhibited greater $(\mathrm{p}<0.05)$ serum concentrations of IL-6, C-reactive protein, and soluble receptors of tumor necrosis factor alpha (sTNFR-p55 and sTNFR-p75). However, no significant differences were reported in serum IL-1 concentrations among patients with or without protein energy malnutrition. Further, serum concentrations of antioxidants (glutathione and vitamin E) was used to assess antioxidant status. Patients with protein energy malnutrition had lower $(\mathrm{p}<0.05)$ levels of circulating antioxidants. 
Collectively, results from this study showed protein energy malnutrition increased inflammatory and ROS reactivity in children suggesting enhanced inflammatory and oxidative stress may contribute to NAFLD (Sauerwein et al., 1997). High protein diets rather than protein energy malnutrition are common in developed countries. However, high protein consumption has been implicated as a risk factor contributing to the increasing prevalence of childhood obesity in Western countries.

\section{Infant Nutrition and Protein}

Cow-milk-based infant formula is widely used in developed countries as a substitute for breastmilk when breastfeeding is not possible. Infant formulas often have higher protein content compared to human breast milk of $\sim 2.2 \mathrm{~g} / 100 \mathrm{kcal}$ and $\sim 1.5 \mathrm{~g} / 100 \mathrm{kcal}$, respectfully. This discrepancy has been associated with weight gain in formula-fed infants and to obesity later-inlife (Tang, 2018). This “early protein hypothesis" suggests that a higher protein intake through infant formulas increase circulating branch chain amino acids (leucine, isoleucine, and valine) and other essential amino acids, which stimulate the secretion of insulin and insulin-like-growth factor 1 (IGF-1) that promotes weight gain in formula-fed infants (Tang, 2018).

In a longitudinal study, formula-fed infants $(\mathrm{n}=1138)$ were randomly assigned to lower protein $(1.77$ - $2.2 \mathrm{~g}$ protein/100 $\mathrm{kcal})$ or high protein $(2.9-4.4 \mathrm{~g}$ protein/100 kcal) groups for the first two years of life (Koletzko et al., 2009). There was no significant differences in infant length among the diet groups. However, infants consuming lower amounts of high-quality protein had reduced risk of weight gain and later risk of obesity compared to infants fed a high protein diet (Koletzko et al., 2009). Marsh et al. (2016) used health economic modeling to predict the long-term economic outcomes of lower protein infant formulas compared to higher protein formulas. The model predicted lower $(\mathrm{p}<0.05)$ lifelong body mass index and incidence of 
obesity in individuals fed low protein infant formula. Therefore, reduce healthcare costs and improve population productivity were predicted for infants provided lower protein infant formulas.

The effects of low protein intake during infancy on body composition and safety has not been extensively assessed, raising safety concerns about adequate growth and maturation (Patro-Golab et al., 2016). Therefore, protein sources with amino acids profiles containing all 10 essential amino acids in high amounts to promote growth by stimulating maximal protein synthesis are required.

\section{Metabolism of Branched Chain Amino Acid}

Branched chain amino acids (BCAAs) are composed of valine, leucine, and isoleucine. BCAAs make up approximately $40 \%$ of the required essential amino acids in humans. Further, the essential amino acids in muscle proteins are comprised of approximately $35 \%$ BCAA (Harper et al., 1984). Circulating levels of BCAAs are highly regulated by systems with rapid responses to excess or deficient conditions.

Figure 2 provides the pathway of BCAA catabolism. Skeletal muscle is considered a primary site for BCAA catabolism due to high concentrations of branched chain aminotransferase (BCAAAT) (O’Connell, 2013). BCAAAT catalyzes the reversible transamination of BCAAs producing branched chain ketoacids (BCKAs) in the cytosol of cells. BCKAs are transported into the mitochondria through the carnitine shuffle. In the mitochondria, BCAAs are degraded by branched chain alpha-keto acid dehydragenase (BCAKADH), to produce BCKAs, that undergo oxidative decarboxylation. Coenzyme A compounds are produced and further oxidized to form acetyl CoA and succinyl CoA. These products then enter the citric acid cycle for use in energy 
production (O'Connell, 2013). However, proteins play a minor role in energy production in the body.

Instead BCAA catabolism is important in the production of additional amino acids such as glutamine and alanine. Glutamine serves as a bioenergetic substrate for cell growth and is found in the highest amount of all amino acids circulating in blood (DeBerardinis et al., 2010). Glutamate is the primary nitrogen donor in the synthesis of nonessential amino acids and is used as a signaling molecule in the regulation of cell proliferation by supporting energy production by entering the citric acid cycle. Additionally, glutamine can be converted to glutamate by the removal of an amino group catalyzed by glutaminase when needed for energy production.

Alanine is utilization in protein synthesis, glucose production in the liver for gluconeogenesis and participates in the glucose alanine cycle during starvation. Alanine produced from BCAAs is transported to the liver for glucose production (O'Connell et al., 2013). Subsequently, dietary protein and BCAAs act as signaling molecules to modulate energy metabolism to sustain homeostasis within the body. Studies have reported increased secretion of insulin like growth factor 1 (IGF-1) potentiates greater body weight gains in infants fed whey-based formulas high in BCAAs (Ong et al.,2009). Therefore, the next section provides an overview of IGF-1.

\section{IGF-1: Role \& Signaling}

IGF-1, secreted mainly from the liver, is considered a somatomedin that regulates animal growth and metabolism by mediating growth hormone (Daughaday et al., 1989; Ohlsson et al., 2009). Synthesis of IGF-1 is dependent on both nutritional status and concentrations of circulating hormones, insulin and growth hormone. Serum IGF-1 concentrations are highly regulated and mediated by IGF binding proteins family and acid-labile subunit (O'Connell et al., 2013). Figure 3, illustrates the IGF-1 dependent pathway for upregulating anabolic metabolism 
through the activation of mammalian target of rapamycin complex 1 (mTORC1) (O'Connell et al., 2013).

Phosphatidylinosotide 3-kinase and protein kinase B are activated by IGF-1 and insulin, resulting in phosphorylation of tuberous sclerosis protein 2 (TSC2). This attenuates the inhibition of the TSC1/TSC2 complex, activating the Ras homolog enriched in brain (Rheb) leading to the final activation mTORC1. Three downstream transcription factors of mTORC1 are critical for anabolism: ribosomal protein S6 kinase 1 (S6K1), SREBP, and eukaryotic translation initiation factor 4E binding protein 1 (4EBP1). S6K1 and SREBP lead to synthesis of proteins and lipids, respectively while 4EBP1 enhances mRNA translation and growth (O’Connell, 2013)

The role of amino acids in the induction of IGF-1 secretion has not been well-studied. However, recently, Wan et al. (2017) provided pigs a normal protein diets (20\% kcal protein) or low protein diets ( $14 \% \mathrm{kcal}$ protein) to determine the role of dietary protein has on IGF-1 expression, secretion, and subsequent hepatic transcriptome alterations. Serum IGF-1 and IGF-1 expression were greater $(\mathrm{p}<0.05)$ in pigs fed a normal protein diet compared to a low protein diet. Additionally, RNA sequencing identified 1,319 genes that were differentially expressed among the diet groups with pathway analysis reporting PPAR pathway to be among the stimulated pathways.

IGF-1 expression was dependent on amino acid concentration and PPAR $\gamma$ in porcine primary hepatocyte models. Dosing with greater amino acid concentrations resulted in upregulation $(\mathrm{p}<$ 0.05) of IGF-1 and PPAR $\gamma$ gene expression. Further, amino acid induced IGF-1 expression was reversed by PPAR $\gamma$ knocked down in HepG2 cells. Collectively, results indicated PPAR $\gamma$ plays an important role in IGF-1 response to dietary protein (Wan et al, 2017). Global gene expression profiles of hepatic transcriptome have the potential to identify the effect of novel dietary protein 
on pathways and gene alterations. This is important given the central role of the liver in toxicology as well as in many aspects of whole-body physiology.

\section{Effect of Protein Source on Hepatic Transcriptome}

Protein sources have been shown to have significant effects on metabolism. Meat and meat products provide excellent sources of high-quality proteins, indicated by high biological values, amino acid scores and digestibility, as well as content of micronutrients required for life-long health (McNeill et al., 2012; Pereira et al., 2013). Fish protein has been suggested to improve insulin sensitivity (Song et al, 2016). However, research on the effect protein source has on physiological and gene-expression responses is limited.

Song and colleagues (2016) investigated the effect of dietary protein source on hepatic transcriptome. Male rats (age 28 days) were fed adequate $(18 \% \mathrm{kcal})$ protein diets based on the AIN-93G diet with protein sourced from beef, pork, chicken, fish (carp), and casein for 7 days. Following 7 days of feeding, rats were euthanized, livers were dissected, and serum was collected for serum biomarker assessment and amino acid profiling. Casein-fed rats were used as the control for all analyses. Results showed total plasma amino acid concentrations were greater $(\mathrm{p}<0.05)$ for all proteins except pork. However, pork protein reduced $(\mathrm{p}<0.05)$ adiposity and hepatic triglycerides concentrations. Fish protein consumption attenuated serum total cholesterol.

Liver transcriptome response was also investigated. Results showed rats fed pork had the lowest number of differentially expressed genes at 609 genes, while rats fed chicken had the largest number of significantly expressed genes at 1258. Pathway analysis using conservative significant thresholds $(\mathrm{p}<0.05$; false discovery rate $(\mathrm{FDR})<0.25)$ indicated transcriptome response from rats consuming chicken and beef were comparable to casein. Interestingly, fish consumption resulted in the greatest number of pathway response alterations. All meat proteins 
enhance expression of antigen production, intracellular trafficking, and oxidoreductivetransformation pathways while suppressing signal transduction and mitochondrial biogenesis. Pork was the only protein source to suppress lipid and amino acid metabolic pathways while both fish and beef protein sources induced amino acid transport. Additionally, fish consumption was the only protein source that reduced nuclear-transport and cofactor metabolism.

Many of the observed differences were attributed to the difference in concentrations of leucine among the protein diets. Leucine has been suggested to mediate the activation of mTORC and its role in the activation of transcript factors involved in protein synthesis, lipid biosynthesis, and cell growth (O'Connell, 2013). Collectively, study results suggested distinct physiological, metabolism and gene expression responses can be implemented in rats fed diets containing different protein sources. However, metabolism changes with age, gender, and dietary protein content and sources. Song and colleagues (2016) investigated $18 \% \mathrm{kcal}$ protein diets derived from carp muscle (sarcoplasmic and myofibrillar proteins). To our knowledge, no studies have investigated the effects of a $10 \% \mathrm{kcal}$ protein diet derived from carp sarcoplasm protein on global and hepatic gene expression.

In reviewing the literature, few studies have investigated the nutritional quality of aquatic proteins compared to other commercial sources or specifically investigated in vivo safety and effects on metabolism. Additionally, most studies focused on safety of high or normal protein intake despite the prevalence of stunted growth and NAFLD due to protein energy malnutrition in many countries. Further, in Western countries there is an initiative to lower protein content in infant formulas to reduce risk of childhood obesity. This has led to research discoveries for a cost-effective and sustainable source of high quality protein that adequately supports growth and is safe when fed at lower levels. 


\section{References}

1. Alrefai WA, Gill RK. (2007). Bile Acid Transporters: Structure, Function, Regulation and Pathophysiological Implications. Pharm Res. 24(10), 1803-1823. doi:10.1007/s11095-007-9289-1

2. Bonjour, J. (2011). Calcium and Phosphate: A Duet of Ions Playing for Bone Health. Journal of the American College of Nutrition. 30, 438S-448S. http://doi:10.1080/07315724.2011.10719988.

3. Browning JD, Horton JD. (2004). Molecular mediators of hepatic steatosis and liver injury. J Clin Invest.114(2):147-152. doi:10.1172/JCI22422

4. Burhans MS, Ntambi JM. (2016). Monounsaturated Fatty Acid Mediated Liver-Adipose Tissue Crosstalk and Metabolic Regulation. In: Hepatic De Novo Lipogenesis and Regulation of Metabolism. Cham: Springer International Publishing, 255-265. doi:10.1007/978-3-319-25065-6_12

5. Buzzetti E, Pinzani M, Tsochatzis EA. (2016). The multiple-hit pathogenesis of nonalcoholic fatty liver disease (NAFLD). Metabolism. 65(8), 1038-1048. doi:10.1016/J.METABOL.2015.12.012

6. Chick, JH. (2001). Invasive Carp in the Mississippi River Basin. Science. 292, 22502251. http://doi:10.1126/science.292.5525.2250.

7. Cuenca-Sanchez, M, Navas-Carrillo D, Orenes-Piñero E. (2015). Controversies Surrounding High-Protein Diet Intake: Satiating Effect and Kidney and Bone Health. Advances in Nutrition: An International Review Journal, 6(3), 260-266. doi:10.3945/an.114.007716. 
8. Cusi K. (2009). Nonalcoholic fatty liver disease in type 2 diabetes mellitus. Curr Opin Endocrinol Diabetes. Obes 16, 141-9.

9. Daughaday WH, Rotwein P. Insulin-like growth factors I and II. Peptide, messenger ribonucleic acid and gene structures, serum, and tissue concentrations. Endocr Rev. 1989; 10(1), 68-91. Epub 1989/02/01. doi: 10.1210/edrv-10-1-68

10. DeBerardinis, RJ, Cheng, T. Q. (2010). The diverse functions of glutamine in metabolism, cell biology and cancer. Oncogene, 29, 313-324.

11. Diehl AM, Day C. (2017). Cause, Pathogenesis, and Treatment of Nonalcoholic Steatohepatitis. Longo DL, ed. N Engl J Med. 377(21), 2063-2072.

12. Ding, H., Li, D., Wei, X., Huang, Y., Cui, S., Xie, H., \& Zhou, T. (2016). Protein-peptide nutritional material prepared from surimi wash-water using immobilized chymotrypsintrypsin. Journal of the Science of Food and Agriculture J. doi:10.1002/jsfa.7969

13. Duarte SMB, Faintuch J, Stefano JT, Oliveira, MB, Mazi DF, Rabelo F. (2014). Hypocaloric high-protein diet improves clinical and biochemical markers in patients with nonalcoholic fatty liver disease (NAFLD) Nutricion hospitalaria. 29, 94-101.

14. Escribano, J, Luque, V, Ferre, N, Zaragoza-Jordana, M, Grote, V., Koletzko, J, Gruszfeld, D, Socha, P, Dain, A., Van Hees, J., Verduci, E., Closa-Monasterolo, R. (2011). Increased Protein Intake Augments Kidney Volume and Function in Healthy Infants. Kidney International. 79, 783-790. http://doi:10.1038/ki.2010.499.

15. FAO, Food and Agriculture Organization of the United Nations. (2016). The State of World Fisheries and Aquaculture, 2016. Rome, Italy: Author. Retrieved from https://www.fao.org/3/a-i5555e.pdf. 
16. Feingold, KR, Grunfeld, C. (2018). Introduction to Lipids and Lipoproteins. Endotext [Internet].

17. Fournier, C, Rizzoli, R, Ammann, P. (2014). Low Calcium-Phosphate Intakes Modulate the Low-Protein Diet-Related Effect on Peak Bone Mass Acquisition: A Hormonal and Bone Strength Determinants Study in Female Growing Rats. Endocrinology, 155(11), 4305-4315. http://doi: 10.1210/en.2014-1308.

18. Friedman, AN. (2004). High-protein diets: potential effects on the kidney in renal health and disease. Am J Kidney Dis. 44(6), 950-962.

19. Gigliotti, J, Jaczynski, J, \& Tou, J. (2008). Determination of the Nutritional Value, Protein Quality and Safety of Krill Protein Concentrate Isolated using an Isoelectric Solubilization/Precipitation Technique. Food Chemistry, 111(1), 209-214. http://doi.org/10.1016/j.foodchem.2008.03.030.

20. Gigliotti, JC, Smith, AL, Jaczynski, J, \& Tou, J C. (2010). Consumption of Krill Protein Concentrate Prevents Early Renal Injury and Nephrocalcinosis in Female SpragueDawley Rats. Urological Research, 39(1), 59-67. http://doi.org/10.1007/s00240-0100261-x.

21. Gordon, CM, Zemel, BS, Wren, TA, Leonard, MB, Bachrach, LK, Rauch, F, Gilsanz, V, Rosen, CJ, Winer, KK. (2017). The Determinants of Peak Bone Mass. Journal of Pediatrics, 180, 261-269. http://doi: 10.1016/j.jpeds.2016.09.056.

22. Harper, AE, Miller, RH, Block, KP. (1984). Branched-chain amino acid metabolism. Апnu. Rev. Nutr. 4, 409-454.

23. Jara, A., Chacon, C., Ibaceta, M., Valdivieso, A., Felsenfeld, A. (2004). Effect of Ammonium Chloride and Dietary Phosphorus in the Azotaemic Rat. Part II-Kidney 
Hypertrophy and Calcium Deposition. Nephrology Dialysis Transplantation, 19(8), 1993-1998. http://doi.org/10.1093/ndt/gfh301.

24. Juraschek, Stephen P, Appel LJ, Anderson CA, Miller ER. (2012). Effect of a HighProtein Diet on Kidney Function in Healthy Adults: Results From the OmniHeart Trial. American Journal of Kidney Diseases, vol. 61(4), 547-554.

doi:https://dx.doi.org/10.1053/j.ajkd.2012.10.017.

25. Kani AH, Alavian SM, Esmaillzadeh A, Adibi P, Azadbakht L. (2014). Effects of a novel therapeutic diet on liver enzymes and coagulating factors in patients with non-alcoholic fatty liver disease: A parallel randomized trial. Nutrition. 30, 814-21.

26. Kargulewicz A, Stankowiak-Kulpa H, Grzymisławski M. (2014). Dietary recommendations for patients with nonalcoholic fatty liver disease. Przeglad Gastroenterologiczny. 9, 18-23.

27. Kerstetter, JE, O’Brian, KO, Insogna, KL. (2003). Dietary Protein, Calcium Metabolism, and Skeletal Homeostasis Revisited. The American Journal of Clinical Nutrition, 78(3). doi:10.1093/ajen/78.3.584s.

28. Koletzko, B, von Kries, R, Closa, R., Escribano, J, Scaglioni, S, Giovannini, M, Beyer, J, Demmelmair, H, Gruszfeld, D, Dobrzanska, A, Sengier, A, Langhendries, J, P, Rolland Cachera M, F, Grote, V. (2009). Lower Protein in Infant Formula is Associated with Lower Weight up to age 2 y: a Randomized Clinical Trial. American Journal of Clinical Nutrition, 89, 1836-1845. http://doi.org/10.3945/ajcn.2008.27091.

29. Kumar V, Deo MG, Ramalingaswami V. (1972) Mechanism of Fatty Liver, in Protein Deficiency. Gastroenterology, 62(3), 445-451. doi: 10.1016/S0016-5085(72)80153-7 
30. Lee, Y, Yang, Y, Huang, P, Li, W, Huang, M, Kao, C, Chenag, Y, Chen. M. (2015). Exercise suppresses COX-2 pro-inflammatory pathway in vestibular migraine. Brain Research Bulletin. 116, 98-105. https://doi.org/10.1016/j.brainresbull.2015.06.005

31. Li T, Chiang JYL. Bile acid signaling in metabolic disease and drug therapy. Pharmacol Rev. 2014, 66(4), 948-983. doi:10.1124/pr.113.008201

32. Lim J, Kim H, Kim K. (2001). Nuclear factor-kappaB regulates cyclooxygenase-2 expression and cell proliferation in human gastric cancer cells. Lab Invest. 81(3), 349-60.

33. Ljubojević, D, Đorđević, V, \& Ćirković, M. (2017). Evaluation of Nutritive Quality of Common Carp, Cyprinus carpio L. IOP Conference Series: Earth and Environmental Science, 85, 012013. http://doi.org/10.1088/1755-1315/85/1/012013.

34. Marsh, K., Moller, J., Basarir, H., Orfanos, P., Detzel, P. (2016). The Economic Impact of Lower Protein Infant Formula for the Children of Overweight and Obese Mothers. Nutrients. 8(1), E18. http://doi.org/10.3390/nu8010018.

35. Martin, W, Armstrong, L, Rodriquez, NR. (2005). Dietary protein intake and renal function. Nutrition and Metabolism, 2(25), 121-140. doi:10.1201/b16308-10.

36. McNeill, S., Van Elswyk, ME., (2012). Red meat in global nutrition. Meat Sci. 92, 166173.

37. Michelotti GA, Machado MV., Diehl AM. (2013). NAFLD, NASH and liver cancer. Nat Rev Gastroenterol Hepatol. 10(11), 656-665. doi:10.1038/nrgastro.2013.183

38. Milanski M, Degasperi G, Coope A (2009). Saturated fatty acids produce an inflammatory response predominantly through the activation of TLR4 signaling in hypothalamus: implications for the pathogenesis of obesity. J Neurosci. 29(2), 359-370. 
39. Millar JS, Stone SJ, Tietge UJF, Tow, B, Billheimer, J, Wong, JS, Hamilton, RL, Farese, RV, Rader, DJ. (2006). Short-term overexpression of DGAT1 or DGAT2 increases hepatic triglyceride but not VLDL triglyceride or apoB production. J Lipid Res. 47(10), 2297-2305. doi:10.1194/jlr.M600213-JLR200

40. Munteanu MA, Nagy GA, Mircea PA. (2016). Current management of NAFLD. Clujul Med. 89(1):19-23. doi:10.15386/cjmed-539

41. Musso G. (2012). Non-alcoholic fatty liver, adipose tissue, and the bone: a new triumvirate on the block. Endocrine. 42(2), 237-239. doi:10.1007/s12020-012-9748-2

42. Naik A, Košir R, Rozman D. (2013). Genomic aspects of NAFLD pathogenesis. Genomics. 102(2), 84-95.

43. O’Connell TM. (2013). The Complex Role of Branched Chain Amino Acids in Diabetes and Cancer. Metabolites, 3, 931-945; doi:10.3390/metabo3040931

44. Ohlsson C, Mohan S, Sjogren K, Tivesten A, Isgaard J, Isaksson O. (2009). The role of liver-derived insulin-like growth factor-I. Endocr Rev. 30(5), 494-535. PubMed Central PMCID: PMC2759708. doi:10.1210/er.2009-0010

45. O’Neill LA., Kaltschmidt C. (1997). NF-kB: a crucial transcription factor for glial and neuronal cell function. Trends Neurosci. 20(6), 252-258.

46. Ong, K., Langkamp, M., Ranke, M., Whitehead, K., Hughes, I., Acerini, C., Dunger. D. (2009). Insulin-like growth factor I concentrations in infancy predict differential gains in body length and adiposity: the Cambridge Baby Growth Study. The American Journal of Clinical Nutrition, 90(1), 156-161, https://doi.org/10.3945/ajcn.2008.27408

47. Patro-Golab, B, Zalewski, BM., Kouwenhoven, SM., Karas, J, Koletzko, B, Bernard van Goudoever, J, Szajewska, H. (2016). Protein Concentration in Milk Formula, Growth, 
and Later Risk of Obesity: A Systematic Review. Journal of Nutrition. 146(3), 551-64. http://doi.org/ 10.3945/jn.115.223651.

48. Pereira, PM., Vicente, AF. (2013). Meat nutritional composition and nutritive role in the human diet. Meat Sci. 93, 586-592.

49. Rao, GN. (2002). Diet and Kidney Diseases in Rats. Toxicology Pathology, 30, 651-656. http://doi.org/10.1080/01926230290166733.

50. Sanyal, AJ, Brunt, EM, Kleiner, DE, Kowdley, KV, Chalasani, N, Lavine, JE, Ratziu, V, McCullough, A. (2015). Endpoints and clinical trial design for nonalcoholic steatohepatitis. Hepatology, 54, 344-353

51. Sauerwein, R, Mulder, J, Mulder, L, Lowe, B, Peshu, N, Demacker, P, van der Meer, J, Marsh K. (1997). Inflammatory mediators in children with protein-energy malnutrition. Am J Clin Nutr. 65(5), 1534-9.

52. Song, S, Hooiveld, G, Li, M, Zhao, F, Zhang, W, Xu, X Muller, M, Li, C, Zhou, G.H. (2016). Distinct physiological, plasma amino acid and liver transcriptome responses to purified dietary beef, chicken, fish, and pork proteins in young rats. Molecular Nutrition \& Food Research. 60. 1199-1205. https://doi.org/10.1002/mnfr.201500789.

53. Strable, MS, Ntambi, JM. (2010). Genetic control of de novo lipogenesis: role in dietinduced obesity. Crit Rev Biochem Mol Biol. 45(3), 199-214. doi:10.3109/10409231003667500

54. Stenvinkel P, Ketteler M, Johnson R., Lindholm B, Pecoits-Filho R, Riella M., Heimbürger O, Cederholm T, Girndt M. (2005). IL-10, IL-6, and TNF- $\alpha$ : Central factors in the altered cytokine network of uremia - The good, the bad, and the ugly. Kidney International. 67(4), 1216-1233. https://doi.org/10.1111/j.1523-1755.2005.00200.x 
55. Tamura S, Shimomura I. (2005). Contribution of adipose tissue and de novo lipogenesis to nonalcoholic fatty liver disease. J Clin Invest. 115(5), 1139-1142. doi:10.1172/JCI24930

56. Tang M. (2018). Protein Intake during the First Two Years of Life and Its Association with Growth and Risk of Overweight. International Journal of Environmental Research \& Public Health. 15(8), E1742. http://doi.org/10.3390/ijerph15081742.

57. Temple J, Cordero P, Li J, Nguyen V, Oben J. (2016). A Guide to Non-Alcoholic Fatty Liver Disease in Childhood and Adolescence. Int J Mol Sci. 17(6), 947.

58. Trauner M, Claudel T, Fickert P, Moustafa T, Wagner M. (2010). Bile acids as regulators of hepatic lipid and glucose metabolism. Dig Dis. 28(1), 220-224. doi:10.1159/000282091

59. Wan X, Wang S, Xu J, Zhuang L, Xing K, Zhang M. (2017). Dietary protein-induced hepatic IGF-1 secretion mediated by PPAR $\gamma$ activation. PLoS ONE, 12(3), e0173174. doi:10.1371/journal.pone.0173174

60. Warren, D, Paker, I, Jaczynski, J, \& Matak, KE. (2018). Nutritional Quality and Physical Characteristics of Soluble Proteins Recovered from Silver Carp. Journal of Food Science, 83(7), 1970-1979. http://doi.org/10.1111/1750-3841.14170.

61. Wibowo, S, Savant, V, Cherian, G, Savage, TF, Velazquez, G, \& Torres, A. (2007). A Feeding Study to Assess Nutritional Quality and Safety of Surimi Wash Water Proteins Recovered by a Chitosan-Alginate Complex. Journal of Food Science, 72(3). http://doi.org/10.1111/j.1750-3841.2007.00291.x. 
62. Yang H-Y, Tzeng Y-H, Chai C-Y, Hsieh A-T, Chen J-R, Chang L-S. (2011). Soy protein retards the progression of non-alcoholic steatohepatitis via improvement of insulin resistance and steatosis. Nutrition. 27, 943-8.

63. Zhang, X., \& Beynen, A. C. (1992). Increasing Intake of Soybean Protein or Casein, but Not Cod Meal, Reduces Nephrocalcinosis in Female Rats. The Journal of Nutrition, 122(11), 2218-2225. http://doi.org/10.1093/jn/122.11.2218.

64. Zutphen, T, Ciapaite, J, Bloks, V, Ackereley, C, Gerding, A, Jurdzinski, A. (2016). Malnutrition-Associated Liver Steatosis and ATP Depletion is caused by Peroxisomal and Mitochondrial Dysfunction. Journal of Hepatology, 65(6), 1198-1208. http://doi.org/10.1016/j.jhep.2016.05.046. 


\section{Figures and Tables}

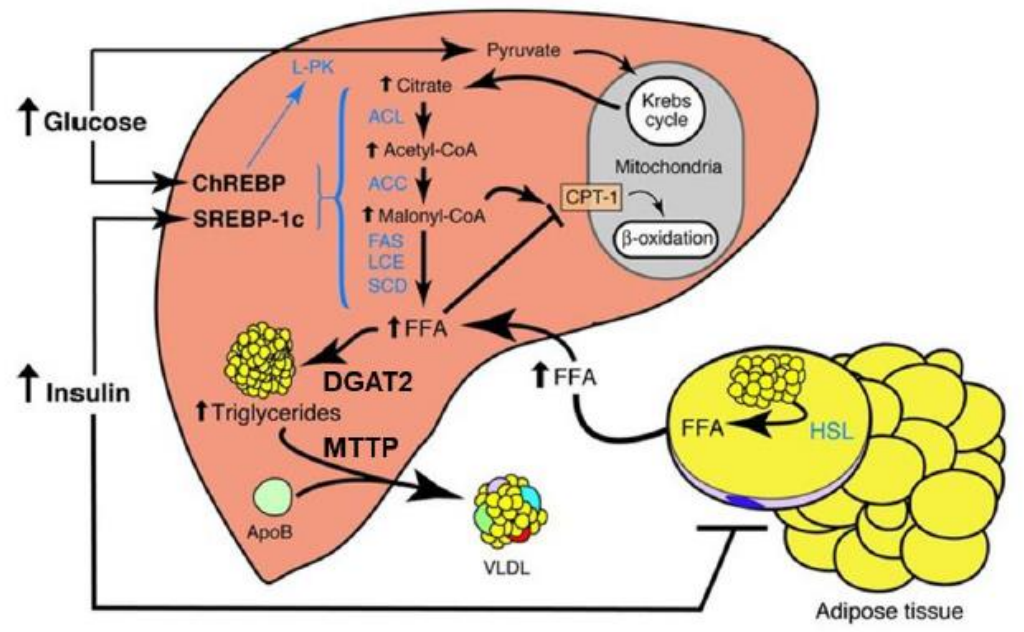

Figure 1: Diagram of de novo lipogenesis, lipid storage, and lipid transport pathways.

Adapted from Millar et al. (2013). Abbreviations: ACC, acetyl co-A carboxylase; ACL, ATP citrate synthase; ApoB, apolipoprotein B; ChREBP, carbohydrate response element bind protein; CPT-1, carnitine palmitoyltransferase 1; diacylglycerol O-acyltransferase 2; FAS, fatty acid synthase; FFA, free fatty acids; HSL, hormone sensitive lipase; LCE, long chain fatty acyl elongase; SCD, stearoyl-CoA desaturase; SREBP-1c; sterol regulatory element binding protein-1c; VLDL, very low-density lipoprotein. 


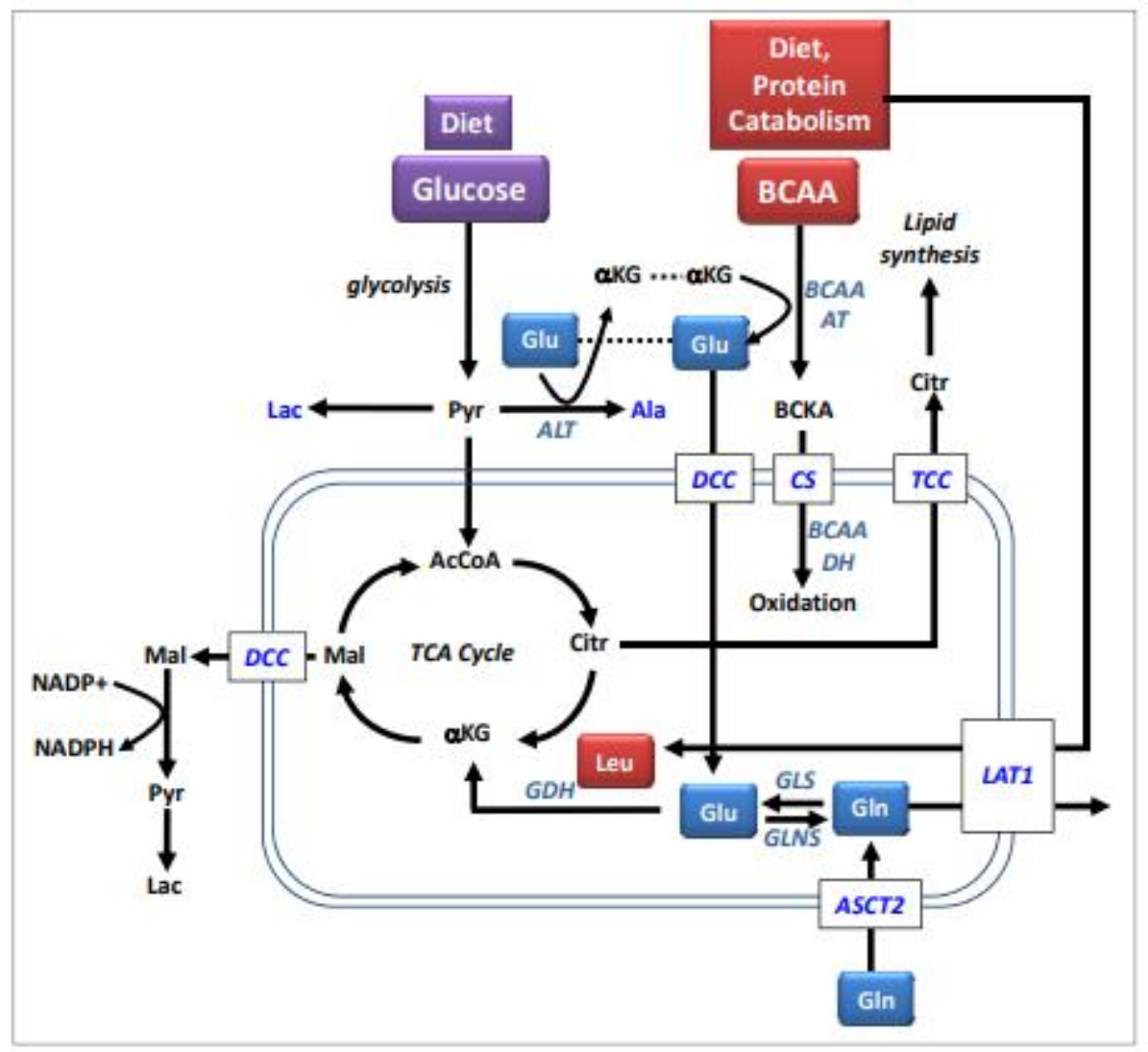

Figure 2: Catabolism pathways for branched chain amino acids. Adapted from O'Connell et al. (2013). Abbreviations: $\alpha \mathrm{KG}, \alpha$-ketoglutarate; AcCoA, acetyl-CoA; Ala, alanine; ALT, alanine aminotransferase; ASCT2, ASC-type amino acid transporters; BCAAAT, branched chain amino acid aminotransferase; $\mathrm{BCAADH}$, branched chain amino acid dehydrogenase; BCKA, branched chain ketoacid; Citr, citrate; CS, carnitine shuttle; DCC, dicarboxylate carrier; Glu, glutamate; GDH, glutamate dehydrogenase; GLS, glutaminase; Gln, glutamine; GLNS, glutamine synthetase; LAT1, Large neutral amino acid transporter; Lac, lactate; Leu, leucine; Mal, malate; NADP+; nicotinamide, adenine dinucleotide phosphate; NADPH, reduced form of nicotinamide, adenine dinucleotide phosphate; Pyr, pyruvate; TCC, tricarboxylate carrier. 


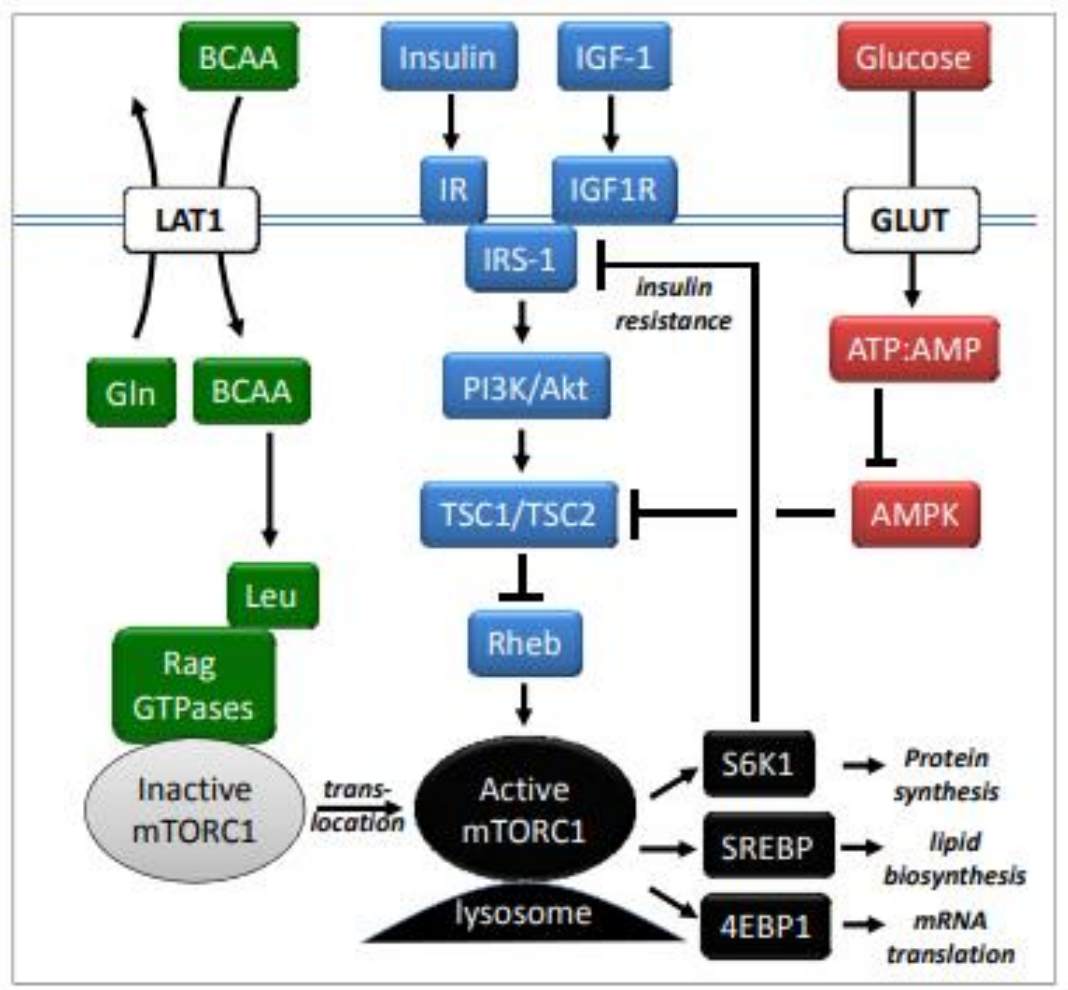

Figure 3: Illustration of branched chain amino acids and IGF-1 role in the activation of mTORC1 and subsequent downstream pathways. Adapted from O'Connell et al., 2013. Abbreviations: Akt, Protein Kinase B; AMP, adenosine monophosphate; AMPK, adenosine monophosphate kinase; ATP, adenosine triphosphate; 4EBP1, eukaryotic translation initiation factor 4E binding protein 1; GLUT, glucose transport protein; IGF-1, insulin-like growth factor-1; IGF1R, IGF1 receptor; IR, insulin receptor; IRS-1, insulin receptor substrate 1; mTORC1, mammalian target of rapamycin complex 1; PI3K, phosphatidylinosotide 3-kinases; Rag GTPases, Rag guanine triphosphate hydrolysis enzymes; Rheb, Ras homolog enriched in brain;; S6K1, ribosomal protein S6 kinase; SREBP, sterol regulatory element-binding protein; TSC1/TSC2, complex of tuberous sclerosis proteins $1 \& 2$ 


\section{Study 1}

\section{Chapter III Study Objectives and Hypotheses}

Previous research investigated in vitro nutritional quality of a water-soluble protein powder derived from silver carp. The results of this study indicated soluble proteins derived from silver carp are nutrient rich and have functional properties; however, bioavailability, protein quality and safety were not considered.

Objective: To evaluate the protein quality of carp sarcoplasm protein (CSP) powder and the effects of low $(10 \% \mathrm{kcal})$ protein diets on growth, body composition, renal markers, and bone health during growth and development.

Hypothesis: Protein quality of CSP is expected to be comparable to popular commercially available milk proteins, casein and whey protein isolate. Collectively, these results are expected to contribute to fish sustainability by using an invasive fish species and by reducing the amount of protein required to be consumed for protein synthesis without negative affecting renal and bone health.

\section{Study 2}

Feeding growing rats diets consisting of $10 \% \mathrm{kcal}$ protein as CSP showed no significant differences in nutrition quality compared to casein and whey protein and was determined to be safe. However, whey protein consumption enhanced adiposity.

Objective: To assess the effect of low protein (10\% kcal) diets consisting of CSP compared to two common commercial protein powders (e.g. casein and whey) on lipid metabolism in liver and adipose tissue compared to a protein deficient diet. Hypothesis: CSP powder is expected to alter lipid metabolism resulting in reduced adiposity, adipose tissue lipolysis, and hepatic lipid accumulation compared to casein and whey protein.

\section{Study 3}

There were few alterations in lipid metabolism in rats fed low protein $(10 \% \mathrm{kcal})$ diets derived from carp, casein, and whey protein. However, differences in amino acid profiles among different protein sources may have altered amino acid catabolism and insulin like growth factor 1 (IGF-1) pathway activation. Additionally, greater hepatic lipid deposition was seen in rats fed a protein deficient diet.

Objectives: To investigate distinct phenotypic and hepatic transcriptome responses due to low protein $(10 \% \mathrm{kcal})$ diets consisting of CSP and milk proteins, casein and whey, in a growing animal model.

Hypothesis: CSP consumption is expected to result in no difference in transcriptome responses compared to casein; whereas, increased branched chain amino acids in whey protein is expected up regulate IGF-1 secretion and related pathways. Further, protein deficient rats are expected to exhibit distinct transcript responses with upregulation of lipid synthesis and storage pathways compared to the protein fed diet groups.

Overall Hypothesis: CSP is a high quality protein comparable to casein and whey protein. Lowering dietary protein content using CSP as the high quality protein is expected to be safe based on hepatic, renal, and bone health markers. Further, CSP may be preferable to whey protein for preventing weight gain due to adiposity. Based on these characteristics, CSP provides a sustainable alternative to current commercial protein powder. 


\section{Chapter IV}

Protein Quality and Safety Evaluation of Sarcoplasmic Protein-Derived from Silver Carp (Hypophthalmichthys molitrix) Using a Rat Model

Derek Warren ${ }^{1}$, Lynsey Soule ${ }^{2}$, Kathryn Taylor ${ }^{1}$, R. Chris Skinner ${ }^{1}$, Kang Mo Ku ${ }^{3}$, Kristen

Matak $^{1}$, Vagner A. Benedito ${ }^{4}$, Janet C. Tou ${ }^{1}$

${ }^{1}$ Division of Animal and Nutritional Sciences, ${ }^{2}$ Department of Biology, ${ }^{4}$ Division of Plant and Soil Sciences, West Virginia University, Morgantown, WV

*Corresponding Author

Janet C. Tou, PhD, P.O. Box 6108, Animal and Nutritional Sciences, West Virginia University, Morgantown, WV 26506, USA.

Phone: (304)293-1919; Fax: (304)293-2232

Email: janet.tou@mail.wvu.edu

Choice of journal section where article should appear: Journal of Food Science 


\begin{abstract}
Consisting of $25-30 \%$ of protein in carp, water-soluble sarcoplasmic proteins lost in wash water, have been recovered and freeze-dried into a protein-rich powder. Study objectives were to evaluate protein quality and safety of a silver carp sarcoplasm derived protein powder (CSP) compared to commercial protein supplements, casein and whey. In vivo protein quality assessment of CSP showed a lower $(p<0.05)$ protein digestibility corrected amino acid score compared to the commercial protein sources. Despite greater $(p<0.05)$ fecal amino acid excretion in casein fed rats, there were no significant differences in liver and muscle amino acid profiles. All low $(10 \% \mathrm{kcal})$ protein diets supported growth with the normal range. However, whey protein supplementation resulted in greater $(p<0.05)$ adiposity. CSP, casein, or whey-fed rats showed no differences in major organ weights, renal damage biomarkers, or bone indices. Collectively, results indicated CSP was safe with protein quality comparable to casein. Keywords: Silver Carp, Sarcoplasm Protein, Protein Quality, Protein Safety, Amino Acid
\end{abstract}

\title{
Practical Application
}

As much as 40 percent of protein in fish can be lost due to sarcoplasmic protein solubilization in processing wash water. Silver carp sarcoplasm protein powder may have similar commercial potential as a sustainable and nutritious alternative to whey and casein proteins. This project aimed to verify the protein quality and safety of this economical protein source. 


\section{Introduction}

Current fishery resources are operating either close to optimal yield or at levels with elevated risk for fish stock depletion (FAO, 2016). In 2016, the Fishes and Aquaculture Organization reported global aquaculture growth declined by $3.3 \%$ meanwhile the human population continues to increase by $1.6 \%$, annually with an expected global population of $\sim 10$ billion by 2050 . A solution for overcoming limitations of sustainable natural fish resources is through utilization of less desirable fish species and fish processing by-products. Silver carp (Hypophthalmichthys molitrix) was imported to the United States in the 1970s for use as filter feeders in aquaculture. Since their unintentional introduction into the wild, silver carp has become an invasive species resulting in negative impacts on the food chain in North American freshwater river systems (Chick, 2001).

Carp is composed of $7.13 \%$ fat, consisting mainly of the health beneficial long-chain omega3 polyunsaturated fatty acids (n-3 PUFAs) (Ljubojević et al., 2017), and 16.69\% protein, comprising all the essential amino acids required by adults and children (Skibniewska, 2013). Silver carp's abundance and nutritional composition makes it a sustainable fish species. Due to its low commercial value as an edible fish in North American, carp may be processed into valueadded products such as surimi. In surimi manufacturing, myofibrilar (muscle) protein is concentrated through repeated washes (Arvanitoyannis \& Kassaveti, 2008). During the washing steps in surimi manufacturing, the water-soluble sarcoplasmic protein comprised of $20-30 \%$ of fish protein, are lost in wash water disposal (Okada, 1999).

Previous research showed silver carp sarcoplasmic proteins in wash water can be recovered and freeze-dried into a protein-rich powder (Warren et al., 2018). However, before carp sarcoplasm protein (CSP) powder can be commercialized, the protein quality and safety of this 
novel protein supplement needs to be evaluated. A study by Wibowo et al. (2007) compared sarcoplasm protein powder recovered from surimi wash water to casein and commercial protein meals. Protein recovered from surimi wash water was determined to be higher in protein quality than casein and commercial protein meals and considered safe based on an absence of significant changes in blood chemistry measurements after feeding $18 \%$ kcal protein to rats aged 40 days for 20 days during the pubescent stage. Our study assessed the effects of lower $(10 \% \mathrm{kcal})$ protein diets on anabolic development of immature (28 day old) rats for 28 days. Reduced protein was used to investigate whether lower protein content may reduce the risk of obesity and renal damage.

An European multi-centered clinical study reported infants receiving a high protein formula resulted in higher kidney volume compared to infants receiving a low protein formula or breastfed infants. Higher kidney volume was attributed to increased renal workload indicated by greater serum urea/creatinine ratios (Escribano et al., 2011). Infant formulas often have higher protein content compared to human milk and this have been related to weight gain and obesity later-in-life (Tang, 2018). In a longitudinal study, infants fed lower amounts of protein, but of high-quality reduced risk of overweight or obesity (Koletzko et al., 2009). Marsh et al. (2016) predicted lower lifelong body mass index and lower incidence of obesity in individuals who received low protein infant formula. However, low protein intake during infancy effects on body composition has not been accessed raising safety concerns about adequate growth and maturation (Patro-Golab et al., 2016).

Therefore, the objectives of this study were to evaluate the protein quality of CSP and effects of a lower $(10 \% \mathrm{kcal})$ protein diets on growth, body composition, renal markers, and bone health during growth and development. Weanling rats were used as a model for studying low 
protein diets from different sources during growth. We hypothesize sarcoplasm protein-derived carp protein quality is comparable to popular commercially available milk proteins, casein and whey protein isolate (WPI) and in turn, can contribute to sustainability by reducing amount of protein consumed for protein synthesis.

\section{Materials and Methods}

\subsection{Protein Powder Production}

Headed and gutted silver carp were purchased from FIN Inc. (Kentucky, USA) and shipped on ice through overnight mail to the West Virginia University Agricultural Sciences Building. Upon delivery, carp was unpacked from ice, immediately twice course ground in a meat grinder (Hobart, model \# 4146 SS). Ground carp was portioned into vacuum-sealed bags and stored at $-80^{\circ} \mathrm{C}$ until processing. CSP powder was recovered according to methods previously described by Warren and colleagues (2018). Briefly, thawed ground carp was mixed with 1:3 deionized and distilled water ( $\mathrm{ddH} 2 \mathrm{O})$ and homogenized on ice for 10 min using a homogenizer (Omni International, model GLH, Kennesaw, GA USA) with a $45 \mathrm{~mm}$ probe (Omni International, model GLH, Kennesaw, GA USA). The homogenized paste was centrifuged (Sorvall, model 728211, Newtown, CT) at 10,000 $\times \mathrm{g}$ for $15 \mathrm{~min}$ at $4^{\circ} \mathrm{C}$ and the sarcoplasmic protein supernatant (i.e. wash water) was collected and filtered through cheesecloth. Centrifugation was repeated on filtered supernatant, and additional supernatant was collected then filtered. Total supernatant (i.e. wash water) was freeze-dried into a powder in a freeze drier (VirTis, model \#35L, SP Industries Inc., Warminster, PA USA). Purity of CSP was verified with proximate composition and sodium dodecyl sulfate-polyacrylamide gel electrophoresis (SDS-PAGE) in Warren et al. (2018). Proximate composition of the CSP powder was determined according to the Association of Official Analytical Chemists (AOAC) methods 
(AOAC, 1995). Proximate composition and SDS-PAGE revealed CSP was $82 \%$ crude protein with the majority consisting of low molecular weight sarcoplasmic proteins (Warren et al., 2018).

\subsection{Research and Development}

Amino acid analysis on the CSP powder was conducted at the University of MissouriColumbia according to the AOAC method 982.30 E (AOAC, 1995). Briefly, samples were hydrolyzed with $6 \mathrm{~N}$ hydrochloric acid at $110^{\circ} \mathrm{C}$ for $24 \mathrm{hr}$. The samples were further oxidized by performic acid overnight at $0-5^{\circ} \mathrm{C}$. Acid hydrolysis was repeated as described followed by a final alkaline hydrolysis with $4.2 \mathrm{~N} \mathrm{NaOH}$ at $110^{\circ} \mathrm{C}$ for $22 \mathrm{hr}$. A Beckman amino acid analyzer (model 6300, Beckman Coulter, Fullerton, Calif., USA) was used to determine the amino acid profile of the hydrolyzed samples using sodium citrate buffers in step gradients with a cation exchange post-column ninhydrin derivation method. Amino acid composition of CSP, casein, and WPI is provided in Table 1 . The CSP powder was vacuum-sealed and stored at $-80{ }^{\circ} \mathrm{C}$ until used for rodent diet formulation.

\subsection{Diets}

The American Institute of Nutrition-93G (AIN-93G), a standard purified diet that meets all the nutrient requirements for growing rats as defined by the National Research Council (1995) was used during the acclimation period. For treatment diets, AIN-93G diet was modified from 20 $\% \mathrm{kcal}$ protein to contain $10 \% \mathrm{kcal}$ protein consisting of either CSP, casein or WPI. Diet ingredients and composition are provided in Table 1. All treatment diets were formulated to be isocaloric with the only difference being the protein source. All diets as well as casein and WPI were purchased from Envigo-Teklad (Madison, WI).

\subsection{Animal Feeding Study}


The rodent feeding study was approved by the Animal Care and Use Committee (ACUC) at West Virginia University (WVU) (ACUC Protocol \# 1603000861) and followed the guidelines set forth by the National Research Council for the Care of Laboratory Animals (2010). Immature (age 28 d) female Sprague-Dawley rats were purchased from Charles River (Worcester, MA). Upon arrival, rats were individually housed in metabolic cages throughout the study to collect urine and feces. Rats were maintained in room at $21^{\circ} \mathrm{C}$ with a $12 \mathrm{~h} \mathrm{light/dark}$ cycle.

Rats were fed the purified AIN-93G diet during acclimation for 7 days. Following acclimation, rats were housed in metabolic cages and randomly assigned ( $\mathrm{n}=8$ rats/group) to one of four experimental diet groups: (1) AIN-93G with 10\% kcal CSP for 4 weeks, (2) AIN-93G with $10 \% \mathrm{kcal}$ casein for 4 weeks, (3) AIN-93G with $10 \% \mathrm{kcal}$ WPI for 4 weeks or, (4) AIN$93 \mathrm{G}$ with $10 \% \mathrm{kcal}$ casein for 2 weeks followed by protein free diet for the remaining 2 weeks to assess endogenous protein loss. Rats were fed 16.0 $\pm 0.2 \mathrm{~g}$ of their assigned diet daily throughout the study duration.

Food intake was recorded then replaced with fresh diet daily. Methods as described by Gigliotti et al. (2008) were used to calculate feed consumption. Rats were provided deionized, distilled water ad libitum. Intake of $\mathrm{ddH}_{2} \mathrm{O}$ was measured weekly by recording pre- and postbottle weights and amount spilled. Urinary and fecal samples were collected weekly. A screen in the metabolism cages separated feces and urine. Ascorbic acid $(0.1 \%)$ was added to the urine collection tube as a preservative with $1 \mathrm{ml}$ of mineral oil added to prevent evaporation. Body weight was recorded weekly. Following 4 weeks of feeding, animals were fasted for $12 \mathrm{~h}$ and euthanized by carbon dioxide inhalation according to the WVU ACUC approved protocol.

\subsection{Protein Quality Measurements}


Protein quality measurements included: true digestibility (D), true biological value (BV), net protein utilization (NPU), amino acid score (AAS), protein digestion corrected for amino acid score (PDCAAS) and relative protein efficiency ratio (PER). Relative PER values were adjusted to the standardized 2.5 value for the casein reference. Protein quality measurements were calculated according to the FAO (1990) where I is nitrogen intake, FN is fecal nitrogen excreted, EFN is endogenous fecal nitrogen, $\mathrm{UN}$ is urinary nitrogen excreted, and EUN is endogenous urinary nitrogen excreted using the formulas below:

$$
\text { True Digestibility }(\mathrm{D})=[\mathrm{I}-(\mathrm{FN}-\mathrm{EFN})) / \mathrm{I}]
$$

True Biological Value $(\mathrm{BV})=[\mathrm{I}-(\mathrm{FN}-\mathrm{EFN})-(\mathrm{UN}-\mathrm{EUN}] /(\mathrm{I}-(\mathrm{FN}-\mathrm{EFN})]$

$$
\text { Net Protein Utilization }(N P U)=[I-(F N-E F N)-(U N-E U N)] / I
$$

Amino Acid Score $(\mathrm{AAS})=($ amount of limiting amino acid in the test protein $/ \mathrm{measured}$ amount of limiting amino acid in reference protein)

Protein Digestibility Corrected for Amino Acid Score $($ PDCAAS $)=($ AAS $) \times D$ Relative Protein Efficiency Ratio (PER) = Body Weight / (I*6.25)

Collected urine samples were centrifuged at $1500 \times \mathrm{g}$ for $10 \mathrm{~min}$ at $4^{\circ} \mathrm{C}$ then aliquoted into fresh tubes and stored at $-20^{\circ} \mathrm{C}$ until assayed for nitrogen content. Fecal samples were freeze-dried for $48 \mathrm{~h}$ then stored at $-20^{\circ} \mathrm{C}$ until assayed for crude nitrogen content. Nitrogen measurements were obtained using the Kjeldahl method (AOAC, 1995).

\subsection{Biological Sample Amino Acid Analysis}

Amino acid profiling was performed on hepatic tissue, gastrocnemius muscle, and fecal samples collected during the final week. Biological samples were freeze-dried (VirTis, model \#35L, SP Industries Inc., Warminster, PA USA). After drying, $15 \mathrm{mg}$ of each biological sample 
was hydrolyzed with $6 \mathrm{~N} \mathrm{HCl}$ in evacuated sealed tubes at $99^{\circ} \mathrm{C}$ for $24 \mathrm{~h}$. Amino acids from hydrolyzed biological samples were isolated and derivatized using the Easy-Fast Amino Acid Sample Testing kit (Phenomenex, Torrance, CA). Amino acids were quantified using a gas chromatograph (GC) (6890N, Agilent Technologies, Santa Clara, CA, USA) coupled to a mass spectrometry (MS) detector (5975B, Agilent Technologies, Santa Clara, CA, USA) equipped with an autosampler (7683B, Agilent Technologies, Santa Clara, CA, USA).

Hepatic, gastrocnemius muscle, and fecal samples were dried and sent to the University of Missouri-Columbia for cysteine, methionine, and tryptophan verification. Cysteine and methionine analysis were conducted according to the AOAC official method 994.12 with performic acid oxidation (AOAC, 1995). While tryptophan analysis was conducted according to the AOAC official method 988.15 with alkaline hydrolysis (AOAC, 1995).

\subsection{Organ Weights and Renal Function Measurements}

Immediately following euthanasia by carbon dioxide inhalation, kidneys and other major organs (i.e. brain, heart, liver, lungs) as well as spleen and thymus were dissected, trimmed, blotted dry, and weighed as indicators of toxicity. The adrenals were weighed as indicators of chronic stress. Retroperitoneal and gonadal fat pads were also excised and weighed. Collected organs and adipose tissue were flash frozen in liquid nitrogen and stored at $-80^{\circ} \mathrm{C}$.

Blood was collected by cardiac puncture and centrifuged at $1500 \times g$ at $4^{\circ} \mathrm{C}$ for $10 \mathrm{~min}$. Serum was collected and stored at $-80^{\circ} \mathrm{C}$ until analyzed. Renal function was assessed by measuring serum blood urea nitrogen $(\mathrm{BUN})$, creatinine, total protein, albumin, calcium $(\mathrm{Ca})$ and phosphorus (P) by enzymatic colorimetric assays using a commercially available Vet- 16 rotor. Absorbance was measured at $595 \mathrm{~nm}$ by Hemagen Analyst automated spectrophotometer (Hemagen Diagnostics Inc., Columbia, MD). 
Determination of urinary calcium (Ca) excretion and kidney $\mathrm{Ca}$ content was conducted according to methods described by Gigliotti and colleagues (2010). Briefly, right kidneys were dried overnight in an oven then ashed in a muffle furnace (Lindberg 515A2, Watertown, WI) for $24 \mathrm{~h}$ at $550^{\circ} \mathrm{C}$. Ashed kidneys were dissolved in $70 \%$ nitric acid $(1 \mathrm{~mL})$. Acidified samples were diluted with $5 \mathrm{~mL}$ of $\mathrm{ddH}_{2} \mathrm{O}$, filtered through Whatman no. 1 paper then diluted (1:50 v/v) to volume with $\mathrm{ddH}_{2} \mathrm{O}$. Urine was diluted $(1: 10 \mathrm{v} / \mathrm{v})$ to volume with $\mathrm{ddH}_{2} \mathrm{O}$. Kidney and urinary $\mathrm{Ca}$ content was measured using inductively coupled plasma optical emission spectroscopy (model P400, Perkin-Elmer, Shelton, CN).

\subsection{Bone Measurements}

Left and right femurs were dissected, defleshed, wrapped in saline soaked gauze, and stored at $-20^{\circ} \mathrm{C}$ until assayed. Bone morphometry measurements of medial lateral width, anterior posterior width, and length were determined using a Vernier caliper (Bel-Art Products, Pequannock, NJ). Length was measured from the medial condyle to greater trochanter. Bones were dried at $110^{\circ} \mathrm{C}$ for $24 \mathrm{~h}$ then weighed using an analytical balance (Mettler Toledo, Columbus, $\mathrm{OH}$ ). Morphometry measurements were averaged for bone pairs (i.e. right and left) after no bilateral differences were determined using paired t-test with significance level set at $p<0.05$.

Bone strength indices were assessed using a TA.XT2i Texture Analyzer (Texture Technologis Corp, NY) equipped with a three-point bending apparatus. The femora were placed on supports (1 mm width at tip for femur) and force applied on the medial surface of the bones by lowering a centrally placed blade $(1 \mathrm{~mm}$ width $)$ at a constant crosshead speed $(0.1 \mathrm{~mm} / \mathrm{sec})$ until the bone was broken. The load cell was $50 \mathrm{~kg}$. The load-deflection data were collected by PC interfaced with the TA.XT2i Texture Analyzer. Sample test distance was set at $10 \mathrm{~mm}$ with a 
signal collection rate of 100 points per sec. A force-displacement curve generated from the biomechanical test was used to determine bone strength measurements. Peak force was measured as the highest load obtained before bone fracture occurs. Ultimate stiffness was measured as the slope of the curve responding to bone stiffness (Skinner et al., 2019). Ultimate bending stress is a normalized calculated force that take into account the size of the bone while Young's Modulus is a normalized calculated bone stiffness taking into account bone size (Skinner et al., 2019).

Total mineral content was determined as described by Skinner et al. (2019). Briefly, bones were ashed in a muffle furnace (Lindberg 515A2, Watertown, WI) for $24 \mathrm{~h}$ at $600^{\circ} \mathrm{C}$ and then weighing ash. To determine bone $\mathrm{Ca}$ and $\mathrm{P}$ content, ashed femurs were dissolved in $70 \%$ nitric acid $(1 \mathrm{~mL})$. Acidified samples were diluted with $5 \mathrm{~mL}$ of $\mathrm{ddH}_{2} \mathrm{O}$, gravity filtered through Whatman no. 1 paper then diluted (1:50 v/v) to volume with $\mathrm{ddH}_{2} \mathrm{O}$. Bone $\mathrm{Ca}$ and phosphorus concentrations were measured using inductively coupled plasma optical emission spectroscopy (model P400, Perkin-Elmer, Shelton, CN).

\subsection{Statistical Analysis}

A completely randomized design was used in the animal feeding study with $n=8$ rats per experimental diet group. Results are expressed as mean \pm standard error of the mean. One-way ANOVA was used to determine differences among diet treatment groups. Post-hoc multiple comparison tests were performed using Tukey's test with treatment differences considered significant at $p<0.05$ and tendency at $p=0.08$. All statistical analyses were performed using JMP 12.2 statistical software package (SAS Institute, Cary, NC).

\section{Results and Discussion}

\subsection{Protein Quality Assessments}


Lowering the protein content of infant formula has been suggested to reduce risk for developing overweight and obesity in children (Koletzko et al., 2009). When the quantity of dietary protein is reduced protein quality and digestibility becomes more important for sustaining growth. In our study, protein true digestibility showed no significant differences between CSP, casein, and WPI. On the other hand, protein quality measurements of biological value (BV) and net protein utilization (NPU) were higher $(p<0.05)$ for CSP compared to WPI, but not casein (Table 2). These measurements indicate rats consuming CSP and casein retained more nitrogen compared to rats consuming WPI. This may be the result of casein being a 'slow' digested protein due to coagulation in the stomach providing a sustained release of amino acids into the blood for better nitrogen retention and utilization by the body (Boirie et al., 1997). Based on comparable nitrogen retention to casein, CSP may also be a 'slow' protein.

PDCAAS is used to calculate protein \% Daily Value on the Nutrition Facts Label and is the routine method of estimating protein quality (Schaafsma, 2000; FOA, 1990). PDCAAS for CSP was lower $(p<0.05)$ than both milk proteins, with casein having the highest PDCAAS $(p<0.05)($ Table 2). Based on dietary amino acid analysis (Table 1), Phenylalanine + Tyrosine was the limiting essential amino acid in CSP at $64.74 \pm 0.65 \mathrm{mg} / \mathrm{g}$ protein, resulting in an amino acid score of 0.61 and subsequently the lowest $(p<0.05)$ PDCAAS $(0.57 \pm 0.01)$. EAA content was higher for whey compared to casein, with the exception of valine and histidine. PDCAAS for WPI $(0.63 \pm 0.01)$ using histidine as the limiting amino acid was low compared to the reported value of 1 for WPI (Hoffman \& Falvo, 2004). However, PDCAAS does not take into consideration the individual amino acids are digested with different efficiencies (Mathai et al., 2017). PDCAAS was adopted as a routine assay for protein quality evaluation because it is rapid; however, it often shows discrepancies compared to PER (Schaafsma, 2000). The protein quality 
calculation used in the development of infant formulas is PER since this calculation measures a protein's ability to support anabolic functions (Gropper, Smith, \& Groff, 2005). In the current study, there were no significant differences in relative and adjusted PER values among CSP, casein, and WPI diet groups (Table 2). Similarly, Gigliotti and colleagues (2008) measured protein quality of protein recovered from krill, another aquatic protein source, reported no significant difference in PER compared to casein protein. WPI was not included in the Gigliotti et al. (2008) study. Wibowo et al. (2007) reported a greater $(p<0.05)$ PER for water-soluble protein extracted from surimi wash water when compared to casein after correcting for lower methionine content. Collectively, the protein quality measurements suggest CSP was comparable to casein and WPI for digestibility, supporting growth, and most protein quality measurements.

\subsection{Fecal and Tissue Amino Acid Profiles}

Of the protein sources, casein-fed rats had the highest $(p<0.05)$ fecal excretion of the essential amino acid valine, as well as non-essential amino acids: alanine, serine, and glutamic acid (Table 3). This may be attributed to higher content of these amino acids in the casein diet with the exception of alanine. This may be because alanine is also used in the urea cycle and excreted as urinary urea. In a study using growing pigs, animals fed a low protein diet reduced nitrogen loss by restricting portal vein transport of alanine to the liver since alanine is a primary nitrogen source for urea production (Wu et al., 2018). In the present study, liver content of ornithine, an intermediate in the urea cycle, showed no significant differences among rats consuming casein, CSP, and WPI.

Rats fed a protein-free diet for 2 weeks significantly lowered liver content of essential amino acids: leucine, methionine + cysteine, phenylalanine + tyrosine, lysine, and histidine compared to rats fed CSP and casein. Lower hepatic essential amino acid content may be due to 
their use for synthesis of non-essential amino acids since almost all essential amino acid catabolic enzymes are found in the liver (Rao, 2002). Of the non-essential amino acids, only liver tyrosine content was lower in rats consuming the protein-free compared to CSP diet; whereas, liver content of alanine, proline, aspartic acid, and tyrosine was lower in in rats consuming the protein-free compared to casein diet (Table 3). However, feeding rats low protein diets as either CSP, casein, or WPI showed no significant differences in amino acid profile in the liver (Table 3). Collectively, fecal and tissue amino acid profiling results indicated among the different protein sources, casein consumption resulted in the lowest nitrogen loss and highest hepatic amino acid retention.

Further, there were no significant differences in muscle weights (Table 4) or gastrocnemius muscle amino acid profile (Table 3) among rat fed CSP, casein, and WPI. Interestingly, rats fed a protein-free diet for 2 weeks also showed no significant differences in gastrocnemius muscle amino acid profile despite lower gastrocnemius muscle weight compared to rats fed low $(10 \% \mathrm{kcal})$ protein diet. This may be due to the ability of numerous transaminases and deaminase in the liver to synthesize different amino acids to adjust amino acid imbalances in the blood and peripheral tissues such as the muscles (Ritskes-Hoitinga et al., 1989).

\subsection{Growth}

Protein energy malnutrition has been characterized by stunted growth and fatty liver (Zutphen et al., 2016; Waterlow, 1992). Growth rate can be influenced by the amount of protein intake and the type of amino acid. Further, high quality proteins can contribute to sustainability by reducing amount of protein consumed for protein synthesis. Lowering protein content of infant formula has been suggested to have minimal effects on short term growth outcomes (Timby et al., 2014). Supplementation of CSP and casein promoted comparable growth indicated 
by no significant differences in body weights throughout the 4 weeks study. On the other hand, rats fed WPI had the highest $(p<0.05)$ body weight starting at 2 weeks (Figure 1). Rats consuming WPI showed no significant differences in gastrocnemius and soleus muscles weights compared to rats consuming CSP and casein (Table 4). There were no significant differences in retroperitoneal adipose among protein-fed groups. However, rats fed WPI had significantly higher gonadal adipose weight compared to rats fed CSP (Table 4). Higher gonadal adipose weight in rats fed WPI may be due to greater feed efficiency than rats fed CSP (Table 2). Additionally, dietary amino acid analysis showed WPI contained more dietary leucine and isoleucine (Table 1). Branch chain amino acids (BCAA): leucine, isoleucine and valine not only act as substrates for protein synthesis and synthesis of nitrogenous compounds, but as signaling molecules regulating glucose and lipid metabolism (Nie et al., 2018). Melnik (2012) reported BCAAs are physiological stimuli of insulin and insulin like growth factor-1 (IGF-1) which stimulates adipogenesis. Collectively, results suggest high consumption of BCAAs may promote adiposity.

In our study, feeding a low $(10 \% \mathrm{kcal})$ protein diets as CSP, casein or WPI supported rat growth within the normal range according to body growth chart for female Sprague-Dawley provided by the animal vendor (Charles River, Worcester, MA). Additionally, measurement of major organ weights as well as spleen and thymus as an indicator of toxicity showed no significant differences for rats fed CSP, casein, and WPI; whereas, feeding a protein-free diet for 2 weeks resulted in lower weight of spleen, thymus, and all major organs except for the brain (Table 4). Koletzko et al. (2009) reported infants fed formulas with lower amounts of higher quality protein resulted in lower body weight with no effects on infant growth. The authors suggested consumption of high-quality proteins at lower levels may reduce risk of obesity later 
in life. Based on our study results, CSP supported comparable growth to casein while WPI increased gonadal adipose compare to CSP. Therefore, CSP may be suitable for supporting growth of lean body mass in lower protein infant formulas.

\subsection{Evaluation of Kidney Health}

Another consideration for decreasing protein content in infant formulas is based on reports of greater kidney size and workload in infants receiving a high versus low protein formula (Escribano et al., 2011). In our study, there were no significant differences in kidney weights among protein-fed groups. Rats fed a protein-free diet for 2 weeks had lower kidney weights (Table 4), but this was no longer significant after correcting for their smaller body size (Supplemental Table 1). Diet is a major factor influencing urinary Ca excretion which promotes hypercalciuria and can lead to nephrocalcinosis (Khan, 2010). A randomized study including 1,090 healthy term infants from five different countries reported hypercalciuria prevalence in $16.8 \%$ of infants fed a high protein formula $(2.05-3.20 \mathrm{~g} / 100 \mathrm{~mL})$ compared to $4.9 \%$ of infants fed a low protein formula (1.25-1.60 g/100 mL) for 3 months (Ferre et al., 2017).

Wibowo et al. (2007) reported 18\% kcal sarcoplasm protein powder was safe based on serum measurements of kidney function using male rats. However, diet-induced nephrocalcinosis is a more common occurrence in female rats (Rao, 2002). The transition of nephrocalcinosis to nephrolithiasis has been implicated in nephropathy and subsequent renal failure in rats (Jara et al., 2004). Zhang and Beynan (1992) reported feeding a 18\% kcal protein diet resulted in greater renal $\mathrm{Ca}$ deposition in rats fed a casein diet compared to cod meal. Gigliotti and colleagues (2010) reported greater kidney weights and renal Ca deposition indicative of nephrocalcinosis in female rats fed $10 \% \mathrm{kcal}$ as casein compared to krill protein concentrate. In the present study, despite higher Ca content in casein and CSP diet compared to WPI diet (Table 1) there were no 
significant differences in urinary $\mathrm{Ca}$ excretion among diet groups (Table 5). There were also no significant differences in histological evidence of $\mathrm{Ca}$ deposits in renal intratubular or interstitial parenchyma (data not shown) or kidney total Ca content among protein-fed rats (Table 5).

Further, there were no significant differences in any serum markers of renal function among rats fed CSP, casein or WPI (Table 5). However, another safety concern is ensuring adequate protein during the growth stage for bone health.

\subsection{Evaluation of Bone Health}

Kerstetter and colleagues (2003) reported low dietary protein intake correlated with reduced bone density and increased rates of bone loss. Reduced bone density and structure during growth and development increases risk of osteoporosis in adulthood (Gordon et al., 2017). In the current study, the importance of adequate protein for bone was indicated by reduced $(p<0.05)$ femur longitudinal growth, bone size, and lower total bone mineral content $(\mathrm{BMC})$ in rats fed a protein-free diet (Table 5). Among rats fed different sources of protein, there were no significant differences $(p<0.05)$ in femoral longitudinal growth, bone size, total BMC, or $\mathrm{Ca}$ and P content (Table 5). Similarly, Gigliotti and colleagues (2010) showed no significant differences in femoral total bone mineral content, $\mathrm{Ca}, \mathrm{P}$ between rats fed $10 \% \mathrm{kcal}$ krill protein concentrate compared to casein.

Chronic low protein diets have been associated with reduced bone mineral density and increased risk of fracture (Kerstetter et al., 2003). In our study there were no significant differences among dietary protein groups in any femur biomechanical strength measurements (Table 5). Similarly, rats fed 10\% krill protein concentrate and casein showed no differences in bone strength (Gigliotti et al., 2010). In our study, absence of adverse bone effects in the proteinfree group may be because two weeks on a protein-free diet may not be a sufficient duration to 
reduce bone strength. There also may have been a bone protective effect with adequate mineral intake provided in the diets. $\mathrm{Ca}$ and $\mathrm{P}$ are critical for formation of hydroxyapatite which provide mechanical resistance of the organic bone matrix (Bonjour, 2011). Fournier et al., (2014) found growing Sprague-Dawley female rats consuming a $\mathrm{Ca}(0.2 \%)$ and $\mathrm{P}(0.16 \%)$ diet for eight weeks attenuated the low protein (5\% casein) diet-related reduction in bone mass and strength. Collectively, the bone results in the current study showed CSP was as safe as casein and WPI.

\section{Conclusion}

The study results indicated protein quality of CSP powder was comparable to standard reference and popular commercially available, casein and WPI. There were no significant differences in liver or muscle amino acid profile among protein protein-fed rats despite higher fecal amino acid excretion in casein-fed rats due to body's compensatory amino acid balance mechanisms. Importantly, feeding low $(10 \% \mathrm{kcal})$ protein diets supported rat growth within the normal range. Additionally, CSP or casein may be better sources for lowering the protein in infant formula to prevent obesity since WPI showed greater gonadal adipose weight. Safety was indicated by rats fed CSP, casein or WPI having higher major organ weights, lymphatic tissue weights compared to rats fed a protein-free diet. There were no significant differences in renal function biomarkers or bone indices. Collectively, the animal study results indicated CSP derived from fish processing waste water provides a high quality that may contribute to sustainability by reducing amount of protein consumed to support adequate body and organ growth. Therefore, CSP merits further investigation in human studies as a novel sustainable protein source for potential commercialization.

\section{Acknowledgements}


We would like to thank Yu-Chun Chiu for her with technical support with amino acid profiling and Barbara Mickelson at Envigo for her assistance with diet formulation. Funding for this project was provided by Grant no. 2015-67017-23084 from the USDA National Institute of Food and Agriculture.

\section{Author Contributions}

D. Warren and L. Soule collected, analyzed and interpreted the data, and drafted the

manuscript. K, Taylor, R. Skinner and K. Ku assisted with data collection and analysis. K. Matak conceived the original idea. V. Benedito contributed to technical details, data interpretations, and manuscript reviewal. J. Tou supervised the project, managed data analysis and interpretation, and critically edited the manuscript drafts.

\section{Conflicts of Interest}

The authors have no conflicts of interest to declare. 


\section{References}

1. Arvanitoyannis, I. S., \& Kassaveti, A. (2008). Fish Industry Waste: Treatments, Environmental Impacts, Current and Potential Uses. International Journal of Food Science \& Technology, 43(4), 726-745. http://doi.org/10.1111/j.13652621.2006.01513.x.

2. Association of Official Analytical Chemists. (1995). Official Methods of Analysis (15th ed.). Washington, DC: Association of Official Analytical Chemists.

3. Boirie, Y., Dangin, M., Gachon, P., Vasson, M.P., Maubois, J.L., Beaufrere, B. (1997). Slow and Fast Dietary Proteins Differently Modulate Postprandial Protein Accretion. Proclamations of National Academy of Sciences. 94, 14930-14935. http://doi: 10.1073/pnas.94.26.14930.

4. Bonjour, J. (2011). Calcium and Phosphate: A Duet of Ions Playing for Bone Health. Journal of the American College of Nutrition. 30, 438S-448S. http://doi:10.1080/07315724.2011.10719988.

5. Chick, J. H. (2001). Invasive Carp in the Mississippi River Basin. Science. 292, 22502251. http://doi:10.1126/science.292.5525.2250.

6. Escribano, J., Luque, V., Ferre, N., Zaragoza-Jordana, M., Grote, V., Koletzko, J., Gruszfeld, D., Socha, P., Dain, A., Van Hees, J., Verduci, E., Closa-Monasterolo, R. (2011). Increased Protein Intake Augments Kidney Volume and Function in Healthy Infants. Kidney International. 79, 783-790. http://doi:10.1038/ki.2010.499.

7. FAO, Food and Agriculture Organization/World Health Organization (1990) Protein quality evaluation; report of the joint FAO/WHO expert consultation. FAO Food and Nutrition Paper 52, Rome, Italy 
8. FAO, Food and Agriculture Organization of the United Nations. (2016). The State of World Fisheries and Aquaculture, 2016. Rome, Italy: Author. Retrieved from https://www.fao.org/3/a-i5555e.pdf.

9. Ferré, N., Rubio-Torrents, C., Luque, V., Closa-Monasterolo, R., Grote, V., Koletzko, B., Socha, P., Gruszfeld, D., Langhendries, J. P., Sengier, A., Verduci, E., Escribano, J. (2017). Influence of Feeding Types during the First Months of Life on Calciuria Levels in Healthy Infants: A Secondary Analysis from a Randomized Clinical Trial. Annals of Nutrition and Metabolism, 70(2), 132-139. http://doi: 10.1159/000468156.

10. Fournier, C., Rizzoli, R., Ammann, P. (2014). Low Calcium-Phosphate Intakes Modulate the Low-Protein Diet-Related Effect on Peak Bone Mass Acquisition: A Hormonal and Bone Strength Determinants Study in Female Growing Rats. Endocrinology, 155(11), 4305-4315. http://doi: 10.1210/en.2014-1308.

11. Gigliotti, J., Jaczynski, J., \& Tou, J. (2008). Determination of the Nutritional Value, Protein Quality and Safety of Krill Protein Concentrate Isolated using an Isoelectric Solubilization/Precipitation Technique. Food Chemistry, 111(1), 209-214. http://doi.org/10.1016/j.foodchem.2008.03.030.

12. Gigliotti, J. C., Smith, A. L., Jaczynski, J., \& Tou, J. C. (2010). Consumption of Krill Protein Concentrate Prevents Early Renal Injury and Nephrocalcinosis in Female Sprague-Dawley Rats. Urological Research, 39(1), 59-67. http://doi.org/10.1007/s00240-010-0261-x.

13. Gordon, C. M., Zemel, B.S., Wren, T. A., Leonard, M. B., Bachrach, L. K., Rauch, F., Gilsanz, V., Rosen, C. J., Winer, K. K. (2017). The Determinants of Peak Bone Mass. Journal of Pediatrics, 180, 261-269. http://doi: 10.1016/j.jpeds.2016.09.056. 
14. Gropper, S. S., Smith, J. L., \& Groff, J. L. (2005). Advanced Nutrition and Human Metabolism (4 ${ }^{\text {th }}$ ed.). CA: Thomson-Wadsworth.

15. Hoffman J. R., Falvo M. J. (2004). Protein - Which is Best? Journal of Sports Science \& Medicine. 3(3). 118-130.

16. Jara, A., Chacon, C., Ibaceta, M., Valdivieso, A., Felsenfeld, A. (2004) Effect of Ammonium Chloride and Dietary Phosphorus in the Azotaemic Rat. Part II-Kidney Hypertrophy and Calcium Deposition. Nephrology Dialysis Transplantation, 19(8), 1993-1998. http://doi.org/10.1093/ndt/gfh301.

17. Kerstetter, J. E., Obrien, K. O., \& Insogna, K. L. (2003). Dietary Protein, Calcium Metabolism, and Skeletal Homeostasis Revisited. American Journal of Clinical Nutrition, 78(3). http://doi.org/10.1093/ajcn/78.3.584s.

18. Khan, S. R. (2010). Nephrocalcinosis in Animal Models with and without Stones. Urological Research, 38(6), 429-438. http://doi.org/10.1007/s00240-010-0303-4.

19. Koletzko, B., von Kries, R., Closa, R., Escribano, J., Scaglioni, S., Giovannini, M., Beyer, J., Demmelmair, H., Gruszfeld, D., Dobrzanska, A., Sengier, A., Langhendries, J., P., Rolland Cachera M., F., Grote, V. (2009). Lower Protein in Infant Formula is Associated with Lower Weight up to age 2 y: a Randomized Clinical Trial. American Journal of Clinical Nutrition, 89, 1836-1845. http://doi.org/10.3945/ajen.2008.27091. 20. Ljubojević, D., Đorđević, V., \& Ćirković, M. (2017). Evaluation of Nutritive Quality of Common Carp, Cyprinus carpio L. IOP Conference Series: Earth and Environmental Science, 85, 012013. http://doi.org/10.1088/1755-1315/85/1/012013. 
21. Marsh, K., Moller, J., Basarir, H., Orfanos, P., Detzel, P. (2016). The Economic Impact of Lower Protein Infant Formula for the Children of Overweight and Obese Mothers. Nutrients. 8(1), E18. http://doi.org/10.3390/nu8010018.

22. Mathai, J. K., Liu, Y., Stein H. H. (2017). Values for Digestible Indispensable Amino Acid Scores (DIAAS) for some Dairy and Plant Proteins may better describe Protein Quality than Values Calculated using the concept for Protein Digestibility-Corrected Amino Acid Scores (PDCAAS). British Journal of Nutrition, 117(4) 490-499. http://doi: $10.1017 / \mathrm{S} 0007114517000125$.

23. Melnik, B.C. (2012). Excessive Leucine-mTORC1-signalling of Cow Milk-based Infant Formula: The Missing Link to Understand Early Childhood Obesity. Journal of Obesity, 2012, 197653. http://doi.org/10.1155/2012/197653.

24. National Research Council. (1995). Nutrient Requirements of Laboratory Animals, $4^{\text {th }}$ ed. National Academy Press, Washington, DC.National Research Council. 2010. Guide for the Care and Use of Laboratory Animals: Eighth Edition - National Research Council, Division on Earth and Life Studies, Institute for Laboratory Animal Research, Committee for the Update of the Guide for the Care and Use of Laboratory Animals - Google Books. In 8th edition. Washington D.C. Available from https://books.google.com/books?hl=en\&amp;lr=\&amp;id=Vp5mgXtxYdQC\&amp;oi=fn d\&amp;pg=PP2\&amp;dq=national+research+council+2010+rats\&amp;ots=FrTgd1JC15 \&amp;sig=eZ_vGWk36QfLScXnMbS__BgT8XU\#v=onepage\&amp; $=$ =national research council 2010 rats\&amp;f=false [accessed 27 February 2018]. 
25. Nie, C., He, T., Zhang, W., Zhang, G., Ma, X. (2018). Branch Chain Amino Acids: Beyond Nutrition Metabolism, International Journal of Molecular Science, 19(4). pii: E954. http://doi.org/10.3390/ijms19040954.

26. Okada, M. (1999). Science of Kamaboko, p. 43, Seizandoshoten, Tokyo, Japan. Seen in Kim, Y.S., Yongsawatdigul, J., Park, J.W. and Thawornchinsombut, S. (2005). Characteristics of Sarcoplasmic Proteins and their Interaction with Myofibrillar Proteins. Journal of Food Biochemistry, 29, 517-532.

27. Patro-Golab, B., Zalewski, BM., Kouwenhoven, SM., Karas, J., Koletzko, B., Bernard van Goudoever, J., Szajewska, H. (2016). Protein Concentration in Milk Formula, Growth, and Later Risk of Obesity: A Systematic Review. Journal of Nutrition. 146(3), 551-64. http://doi.org/ 10.3945/jn.115.223651.

28. Rao, G., N. (2002). Diet and Kidney Diseases in Rats. Toxicology Pathology, 30, 651656. http://doi.org/10.1080/01926230290166733.

29. Ritskes-Hoitinga, J., Lemmens, A., G., Beynen, A., C. (1989). Nutrition and Kidney Calcification in Rats. Lab Animal, 23, 313-318. http://doi.org/10.1258/002367789780745944.

30. SAS Sprague Dawley Rat | Charles River. (2019). Retrieved February 10, 2019, from https://www.criver.com/products-services/find-model/sas-sprague-dawleyrat?region $=3611$

31. Schaafsma, G. (2000). The Protein Digestibility-Corrected Amino Acid Score. Journal of Nutrition, 130(7). http://doi.org/10.1093/jn/130.7.1865s.

32. Skibniewska, K., Zakrzewski, J., Kłobukowski, J., Białowiąs, H., Mickowska, B., Guziur, J., Walczak, Z., Szarek, J. (2013). Nutritional Value of the Protein of Consumer Carp 
Cyprinus carpio L. Czech Journal of Food Sciences, 31(4), 313-317. http://doi.org/10.17221/337/2012-cjfs.

33. Skinner, R. C., Gigliotti, J. C., Taylor, K. H., Warren, D. C., Benedito, V. A., Tou, J, C. (2019). Caloric Substitution of Diets with Apple Pomace was Determined to be Safe for Renal and Bone Health Using a Growing Rat Model. European Journal of Nutrition and Food Safety, 9(3), 248-259. http://doi.org/10.9734/EJNFS/2019/v9i330063

34. Tang M. (2018). Protein Intake during the First Two Years of Life and Its Association with Growth and Risk of Overweight. International Journal of Environmental Research \& Public Health. 15(8), E1742. http://doi.org/10.3390/ijerph15081742.

35. Timby, N., Domellöf, E., Hernell, O., Lönnerdal, B., Domellöf, M. (2014). Neurodevelopment, nutrition, and growth until 12 mo of age in infants fed a low-energy, low-protein formula supplemented with bovine milk fat globule membranes: a randomized controlled trial. American Journal of Clinical Nutrition, 99(4), 860-868.

36. Warren, D., Paker, I., Jaczynski, J., \& Matak, K. E. (2018). Nutritional Quality and Physical Characteristics of Soluble Proteins Recovered from Silver Carp. Journal of Food Science, 83(7), 1970-1979. http://doi.org/10.1111/1750-3841.14170.

37. Waterlow, J.C. (1992). Protein-Energy Malnutrition. London: Edward Arnold

38. Wibowo, S., Savant, V., Cherian, G., Savage, T. F., Velazquez, G., \& Torres, J. A. (2007). A Feeding Study to Assess Nutritional Quality and Safety of Surimi Wash Water Proteins Recovered by a Chitosan-Alginate Complex. Journal of Food Science, 72(3). http://doi.org/10.1111/j.1750-3841.2007.00291.x.

39. Wu, L., Zhang, X., Tang, Z., Li, Y., Li, T., Xu, Q., Zhen, J., Huang, F., Yang, J., Chen, C., Wu, Z., Li, M., Sun, J., Chen, J., An, R., Zhao, S., Jiang, Q., Zhu, W., Yin, Y., Sun, Z. 
(2018). Low-Protein Diets Decrease Porcine Nitrogen Excretion but with Restrictive Effects on Amino Acid Utilization. Journal of Agricultural and Food Chemistry, 66(31), 8262-7271. http://doi: 10.1021/acs.jafc.8b03299.

40. Zhang, X., \& Beynen, A. C. (1992). Increasing Intake of Soybean Protein or Casein, but Not Cod Meal, Reduces Nephrocalcinosis in Female Rats. The Journal of Nutrition, 122(11), 2218-2225. http://doi.org/10.1093/jn/122.11.2218.

41. Zutphen, T. V., Ciapaite, J., Bloks, V. W., Ackereley, C., Gerding, A., Jurdzinski, A., et al. (2016). Malnutrition-Associated Liver Steatosis and ATP Depletion is caused by Peroxisomal and Mitochondrial Dysfunction. Journal of Hepatology, 65(6), 1198-1208. http://doi.org/10.1016/j.jhep.2016.05.046. 
Table 1: Amino acid and nutritional composition of different protein sources and ingredient formulation of experimental protein diets.

\begin{tabular}{|c|c|c|c|c|}
\hline & CSP & Casein* & WPI* & No-Protein: \\
\hline \multicolumn{5}{|l|}{ Component (\%) } \\
\hline Moisture & 6.86 & 11.1 & 4.7 & - \\
\hline Protein & 75.64 & 85.5 & 93.9 & - \\
\hline Lipid & 2.77 & 0.6 & 0.3 & - \\
\hline Ash & 15.8 & 2.8 & 1.5 & - \\
\hline \multicolumn{5}{|c|}{ Essential Amino Acid (mg/g protein) } \\
\hline Valine & $47.21 \pm 0.18$ & 70 & 56 & - \\
\hline Leucine & $62.96 \pm 0.26$ & 94 & 143 & - \\
\hline Isoleucine & $38.23 \pm 0.14$ & 58 & 63 & - \\
\hline Threonine & $32.13 \pm 0.21$ & 44 & 53 & - \\
\hline Methionine + Cysteine & $26.35 \pm 0.27$ & 31 & 64 & - \\
\hline Phenylalanine + Tyrosine & $64.74 \pm 0.65$ & 105 & 80 & - \\
\hline Lysine & $74.46 \pm 0.44$ & 82 & 112 & - \\
\hline Histidine & $43.62 \pm 0.24$ & 29 & 20 & - \\
\hline Tryptophan & $11.49 \pm 0.16$ & 12 & 24 & - \\
\hline Arginine & $37.72 \pm 0.21$ & 39 & 30 & - \\
\hline Total Essential Amino Acid & 438.91 & 506 & 563 & - \\
\hline \multicolumn{5}{|c|}{ Non-essential amino acids (mg/g protein) } \\
\hline Alanine & $48.86 \pm 0.22$ & 32 & 57 & - \\
\hline Glycine & $51.07 \pm 0.27$ & 19 & 18 & - \\
\hline Serine & $28.17 \pm 0.28$ & 56 & 45 & - \\
\hline Proline & $23.31 \pm 1.05$ & 84 & 45 & - \\
\hline Aspartic Acid & $81.58 \pm 0.42$ & 71 & 125 & - \\
\hline Glutamic Acid & $83.74 \pm 0.48$ & 229 & 176 & - \\
\hline Tyrosine & $23.21 \pm 0.18$ & 54 & 42 & - \\
\hline Cysteine & $9.88 \pm 0.03$ & 4 & 40 & - \\
\hline Taurine & $25.98 \pm 0.45$ & ND & ND & - \\
\hline Total NEAA & 375.8 & 549 & 548 & - \\
\hline \multicolumn{5}{|l|}{ Minerals (mg/g) } \\
\hline Calcium & $295 * *$ & 200 & 76 & - \\
\hline Phosphorus & $2188^{* *}$ & 8000 & ND & - \\
\hline Sodium & $818^{* *}$ & $<100$ & 560 & - \\
\hline Magnesium & $188 * *$ & $<200$ & ND & - \\
\hline \multicolumn{5}{|c|}{ Selected Nutrient Information* } \\
\hline Protein (\%) & 10 & 10 & 10.3 & 0 \\
\hline Carbohydrate (\%) & 66.9 & 67.8 & 68.1 & 78.1 \\
\hline Fat $(\%)$ & 7 & 7.1 & 7 & 7 \\
\hline Energy (kcal/g) & 3.7 & 3.8 & 3.8 & 3.8 \\
\hline \multicolumn{5}{|l|}{ Ingredient $(\mathrm{g} / \mathrm{kg})^{*}$} \\
\hline Whey Protein Isolate & - & - & 111 & - \\
\hline Casein & - & 115 & - & - \\
\hline Carp Protein & 131.5 & - & - & - \\
\hline Corn Starch & 482.236 & 492.036 & 495.286 & 605.986 \\
\hline
\end{tabular}




\begin{tabular}{lllll} 
Maltodextrin & 132 & 132 & 132 & 132 \\
Sucrose & 100 & 100 & 100 & 100 \\
Soybean Oil & 66.5 & 70 & 70 & 70 \\
Cellulose & 50 & 50 & 50 & 50 \\
Mineral Mix & 13.4 & 13.4 & 13.4 & 13.4 \\
Calcium Phosphate & 0.75 & 9.8 & 13.2 & 13.4 \\
Calcium Carbonate & 11.1 & 5.25 & 2.6 & 2.7 \\
Vitamin Mix & 10 & 10 & 10 & 10 \\
Choline Bitartate & 2.5 & 2.5 & 2.5 & 2.5 \\
TBHQ*** & 0.014 & 0.014 & 0.014 & 0.014 \\
\hline
\end{tabular}

ND; no data

*Received from Envigo-Teklad (Madison, WI)

***Based on Warren et al., 2018.

***Tertiary butylhydroquinone

Values are mean \pm SEM with $\mathrm{n}=3$ samples/group. 
Table 2: Protein quality and growth of female rats fed $10 \%$ protein diets consisting of casein, whey protein isolate, carp sarcoplasmic protein, or 2 weeks on $10 \%$ casein diet followed by a no-protein diet.

\begin{tabular}{|c|c|c|c|c|}
\hline & CSP & Casein & WPI & No-Protein \\
\hline \multicolumn{5}{|l|}{ Protein Quality Measure } \\
\hline True Digestibility (\%) & $94.43 \pm 1.15$ & $91.33 \pm 2.37$ & $94.03 \pm 1.06$ & - \\
\hline Biological Value & $0.75 \pm 0.04^{\mathrm{a}}$ & $0.73 \pm 0.02^{\mathrm{a}}$ & $0.61 \pm 0.04^{\mathrm{b}}$ & - \\
\hline Net Protein Utilization $(\%)$ & $71.32 \pm 3.99^{a}$ & $66.78 \pm 1.88^{\mathrm{a}}$ & $52.99 \pm 4.83^{\mathrm{b}}$ & - \\
\hline Amino Acid Score & $0.61^{*}$ & 1 & $0.68^{*}$ & - \\
\hline PDCAAS & $0.57 \pm 0.01^{\mathrm{c}}$ & $0.91 \pm 0.02^{\mathrm{a}}$ & $0.63 \pm 0.01^{\mathrm{b}}$ & - \\
\hline Relative Protein Efficiency Ratio (g body wt/g protein) & $1.66 \pm 0.06$ & $1.87 \pm 0.08$ & $1.81 \pm 0.11$ & - \\
\hline Adjusted Protein Efficiency Ratio & 2.22 & 2.5 & 2.43 & - \\
\hline Fecal Nitrogen Excretion (mg/day) & $20.57 \pm 2.50^{\mathrm{ab}}$ & $30.33 \pm 3.92^{\mathrm{a}}$ & $30.36 \pm 6.07^{\mathrm{a}}$ & $8.41 \pm 0.98^{b}$ \\
\hline Urinary Nitrogen Excretion (mg/day) & $60.81 \pm 7.03^{b}$ & $58.36 \pm 3.97^{\mathrm{b}}$ & $91.10 \pm 8.37^{\mathrm{a}}$ & $10.61 \pm 1.72^{\mathrm{c}}$ \\
\hline \multicolumn{5}{|l|}{ Growth Parameters } \\
\hline Total diet intake ( $\mathrm{g} / 4$ weeks) & $449.98 \pm 3.13^{\mathrm{a}}$ & $441.65 \pm 6.99^{\mathrm{a}}$ & $460.49 \pm 1.79^{\mathrm{a}}$ & $380.59 \pm 11.52^{\mathrm{b}}$ \\
\hline Feed efficiency (g body wt/g diet intake) & $0.16 \pm 0.004^{b}$ & $0.19 \pm 0.009^{\mathrm{ab}}$ & $0.20 \pm 0.006^{\mathrm{a}}$ & $0.04 \pm 0.007^{c}$ \\
\hline Final Body weight $(\mathrm{g})$ & $202.85 \pm 3.33^{\mathrm{b}}$ & $207.26 \pm 2.89^{b}$ & $219.66 \pm 2.66^{\mathrm{a}}$ & $141.70 \pm 2.98^{\mathrm{c}}$ \\
\hline Total body weight gain (g/4 week) & $73.93 \pm 1.71^{\mathrm{b}}$ & $82.68 \pm 4.04^{\mathrm{ab}}$ & $93.69 \pm 3.11^{\mathrm{a}}$ & $15.82 \pm 2.75^{\mathrm{c}}$ \\
\hline \multicolumn{5}{|c|}{ *Phenylalanine + Tyrosine is the first limiting amino acid of CSP; Histidine is the first limiting amino acid for WPI } \\
\hline \multirow{4}{*}{\multicolumn{5}{|c|}{$\begin{array}{l}\text { True Digestibility }(\mathrm{D})=[\mathrm{I}-(\mathrm{FN}-\mathrm{EFN})] / \mathrm{I}] ; \text { True Biological Value }(\mathrm{BV})=[\mathrm{I}-(\mathrm{FN}-\mathrm{EFN})-(\mathrm{UN}-\mathrm{EUN})] /[\mathrm{I}-(\mathrm{FN}-\mathrm{EFN})] ; \mathrm{Net} \\
\text { Protein Utilization }(\mathrm{NPU})=[\mathrm{I}-(\mathrm{FN}-\mathrm{EFN})-(\mathrm{UN}-\mathrm{EUN})] / \mathrm{I} \text {; Amino Acid Score }=(\text { amount of limiting amino acid in the test } \\
\text { protein /measured amount of limiting amino acid in reference protein }) \text {; Protein Digestion Corrected for Amino Acid Score }(\mathrm{PDCAAS}) \\
=\text { Amino Acid Score x True Digestibility; Relative Protein Efficiency Ratio }(\mathrm{PER})=\text { Body Weight } /\left(\mathrm{I}^{*} 6.25\right) ; \text { Corrected PER }=\text { PER } \times \\
\text { 1.34. }\end{array}$}} \\
\hline & & & & \\
\hline & & & & \\
\hline & & & & \\
\hline \multicolumn{5}{|c|}{$\begin{array}{l}\text { Values are mean } \pm \text { SEM of } n=8 \text { rats/group. Different superscript letters a and } \mathrm{b} \text { within the same row indicate significant difference at } \\
p<0.05 \text { by One-way ANOVA followed by Tukey's test }\end{array}$} \\
\hline
\end{tabular}


Table 3. Fecal, hepatic, and skeletal muscle amino acid profile of female rats fed $10 \%$ protein diets consisting of carp sarcoplasmic protein, casein, whey protein isolate, or 2 weeks on $10 \%$ casein diet followed by a no-protein diet.

\begin{tabular}{|c|c|c|c|c|c|c|c|c|c|c|c|c|}
\hline \multirow[b]{2}{*}{$\begin{array}{c}\text { Amino acids } \\
\text { (mg/g sample) }\end{array}$} & \multicolumn{4}{|c|}{ Feces } & \multicolumn{4}{|c|}{ Liver } & \multicolumn{4}{|c|}{ Gastrocnemius Muscle } \\
\hline & CSP & Casein & WPI & $\begin{array}{c}\text { No- } \\
\text { Protein }\end{array}$ & CSP & Casein & WPI & $\begin{array}{c}\text { No- } \\
\text { Protei } \\
\text { n } \\
\end{array}$ & CSP & Casein & WPI & $\begin{array}{c}\text { No- } \\
\text { Protein }\end{array}$ \\
\hline \multicolumn{13}{|l|}{$\begin{array}{l}\text { Essential amino } \\
\text { acids }\end{array}$} \\
\hline Valine & $\begin{array}{l}0.40 \pm \\
0.03^{\mathrm{b}}\end{array}$ & $\begin{array}{c}0.56 \pm \\
0.03^{\mathrm{a}}\end{array}$ & $\begin{array}{l}0.39 \pm \\
0.03^{\mathrm{b}}\end{array}$ & $\begin{array}{l}0.32 \pm \\
0.02^{\mathrm{b}}\end{array}$ & $\begin{array}{c}3.03 \pm \\
0.14\end{array}$ & $\begin{array}{c}3.16 \pm \\
0.13\end{array}$ & $\begin{array}{c}2.67 \pm \\
0.21\end{array}$ & $\begin{array}{c}2.37 \pm \\
0.30\end{array}$ & $\begin{array}{c}2.60 \pm \\
0.29\end{array}$ & $\begin{array}{c}2.67 \pm \\
0.29\end{array}$ & $\begin{array}{c}2.82 \pm \\
0.28\end{array}$ & $\begin{array}{c}2.57 \pm \\
0.23\end{array}$ \\
\hline Leucine & $\begin{array}{l}0.55 \pm \\
0.05^{\mathrm{ab}}\end{array}$ & $\begin{array}{l}0.7 \pm \\
0.01^{\mathrm{a}}\end{array}$ & $\begin{array}{l}0.58 \pm \\
0.04^{\mathrm{ab}}\end{array}$ & $\begin{array}{c}0.47 \pm \\
0.03^{\mathrm{b}}\end{array}$ & $\begin{array}{c}6.95 \pm \\
0.28^{\mathrm{a}}\end{array}$ & $\begin{array}{c}7.22 \pm \\
0.26^{\mathrm{a}}\end{array}$ & $\begin{array}{l}6.05 \pm \\
0.49^{\mathrm{ab}}\end{array}$ & $\begin{array}{l}5.27 \pm \\
0.56^{\mathrm{b}}\end{array}$ & $\begin{array}{c}7.26 \pm \\
0.42\end{array}$ & $\begin{array}{c}7.51 \pm \\
0.27\end{array}$ & $\begin{array}{l}7.94 \pm \\
0.18\end{array}$ & $\begin{array}{c}7.50 \pm \\
0.26\end{array}$ \\
\hline Isoleucine & ND & ND & ND & ND & $\begin{array}{c}1.79 \pm \\
0.08\end{array}$ & $\begin{array}{c}1.87 \pm \\
0.08\end{array}$ & $\begin{array}{c}1.66 \pm \\
0.13\end{array}$ & $\begin{array}{c}1.52 \pm \\
0.20\end{array}$ & $\begin{array}{c}2.08 \pm \\
0.24\end{array}$ & $\begin{array}{c}2.32 \pm \\
0.30\end{array}$ & $\begin{array}{c}2.28 \pm \\
0.29\end{array}$ & $\begin{array}{c}2.20 \pm \\
0.23\end{array}$ \\
\hline Threonine & $\begin{array}{l}0.39 \pm \\
0.05^{\mathrm{ab}}\end{array}$ & $\begin{array}{c}0.46 \pm \\
0.3^{\mathrm{a}}\end{array}$ & $\begin{array}{l}0.42 \pm \\
0.03^{\mathrm{ab}}\end{array}$ & $\begin{array}{c}0.32 \pm \\
0.02^{\mathrm{b}}\end{array}$ & $\begin{array}{l}3.04 \pm \\
0.15\end{array}$ & $\begin{array}{c}3.26 \pm \\
0.12\end{array}$ & $\begin{array}{l}2.78 \pm \\
0.26\end{array}$ & $\begin{array}{c}2.41 \pm \\
0.31\end{array}$ & $\begin{array}{c}3.30 \pm \\
0.40\end{array}$ & $\begin{array}{c}3.03 \pm \\
0.31\end{array}$ & $\begin{array}{c}3.38 \pm \\
0.35\end{array}$ & $\begin{array}{c}3.02 \pm \\
0.31\end{array}$ \\
\hline $\begin{array}{l}\text { Methionine + } \\
\text { Cysteine }\end{array}$ & $\begin{array}{c}0.45 \pm \\
0.04\end{array}$ & $\begin{array}{c}0.50 \pm \\
0.04\end{array}$ & $\begin{array}{l}0.44 \pm \\
0.03\end{array}$ & $\begin{array}{c}0.45 \pm \\
0.04\end{array}$ & $\begin{array}{l}2.14 \pm \\
0.06^{\mathrm{ab}}\end{array}$ & $\begin{array}{c}2.22 \pm \\
0.09^{a}\end{array}$ & $\begin{array}{l}1.94 \pm \\
0.17^{\mathrm{ab}}\end{array}$ & $\begin{array}{l}1.59 \pm \\
0.22^{\mathrm{b}}\end{array}$ & $\begin{array}{l}3.28 \pm \\
0.06\end{array}$ & $\begin{array}{l}3.00 \pm \\
0.22\end{array}$ & $\begin{array}{c}3.04 \pm \\
0.18\end{array}$ & $\begin{array}{c}2.93 \pm \\
0.18\end{array}$ \\
\hline $\begin{array}{l}\text { Phenylalanine }+ \\
\text { Tyrosine }\end{array}$ & $\begin{array}{c}0.25 \pm \\
0.02\end{array}$ & $\begin{array}{c}0.28 \pm \\
0.02\end{array}$ & $\begin{array}{c}0.25 \pm \\
0.02\end{array}$ & $\begin{array}{c}0.22 \pm \\
0.02\end{array}$ & $\begin{array}{c}7.56 \pm \\
0.20^{\mathrm{a}}\end{array}$ & $\begin{array}{c}7.88 \pm \\
0.17^{a}\end{array}$ & $\begin{array}{l}6.58 \pm \\
0.42^{\mathrm{ab}}\end{array}$ & $\begin{array}{l}5.35 \pm \\
0.46^{\mathrm{b}}\end{array}$ & $\begin{array}{c}8.20 \pm \\
0.53\end{array}$ & $\begin{array}{c}7.10 \pm \\
1.11\end{array}$ & $\begin{array}{c}8.23 \pm \\
1.00\end{array}$ & $\begin{array}{c}5.36 \pm \\
1.09\end{array}$ \\
\hline Lysine & $\begin{array}{c}0.41 \pm \\
0.19\end{array}$ & $\begin{array}{c}0.54 \pm \\
0.15\end{array}$ & $\begin{array}{c}0.16 \pm \\
0.07\end{array}$ & $\begin{array}{c}0.19 \pm \\
0.12\end{array}$ & $\begin{array}{c}4.74 \pm \\
0.44^{\mathrm{a}}\end{array}$ & $\begin{array}{c}5.28 \pm \\
0.29^{\mathrm{a}}\end{array}$ & $\begin{array}{l}3.99 \pm \\
0.43^{\mathrm{ab}}\end{array}$ & $\begin{array}{l}3.03 \pm \\
0.49^{\mathrm{b}}\end{array}$ & $\begin{array}{c}6.23 \pm \\
0.93\end{array}$ & $\begin{array}{c}6.75 \pm \\
0.84\end{array}$ & $\begin{array}{c}7.27 \pm \\
0.87\end{array}$ & $\begin{array}{c}6.33 \pm \\
0.70\end{array}$ \\
\hline Histidine & $\begin{array}{l}0.25 \pm \\
0.01^{\mathrm{ab}}\end{array}$ & $\begin{array}{c}0.31 \pm \\
0.02^{\mathrm{a}}\end{array}$ & $\begin{array}{l}0.24 \pm \\
0.01^{\mathrm{ab}}\end{array}$ & $\begin{array}{c}0.22 \pm \\
0.01^{\mathrm{b}}\end{array}$ & $\begin{array}{c}3.45 \pm \\
0.25^{\mathrm{a}}\end{array}$ & $\begin{array}{c}3.47 \pm \\
0.19^{\mathrm{a}}\end{array}$ & $\begin{array}{l}2.79 \pm \\
0.27^{\mathrm{ab}}\end{array}$ & $\begin{array}{l}2.28 \pm \\
0.33^{\mathrm{b}}\end{array}$ & $\begin{array}{c}3.66 \pm \\
0.31\end{array}$ & $\begin{array}{c}4.59 \pm \\
0.40\end{array}$ & $\begin{array}{c}4.18 \pm \\
0.31\end{array}$ & $\begin{array}{c}3.96 \pm \\
0.39\end{array}$ \\
\hline Tryptophan & $\begin{array}{c}0.05 \pm \\
0.01\end{array}$ & $\begin{array}{c}0.06 \pm \\
0.01\end{array}$ & $\begin{array}{c}0.04 \pm \\
0.01\end{array}$ & $\begin{array}{c}0.05 \pm \\
0.01\end{array}$ & $\begin{array}{l}0.31 \pm \\
0.06^{\mathrm{b}}\end{array}$ & $\begin{array}{l}0.55 \pm \\
0.09^{\mathrm{ab}}\end{array}$ & $\begin{array}{l}0.42 \pm \\
0.04^{\mathrm{ab}}\end{array}$ & $\begin{array}{l}0.66 \pm \\
0.04^{\mathrm{b}}\end{array}$ & $\begin{array}{l}0.95 \pm \\
0.03\end{array}$ & $\begin{array}{c}0.91 \pm \\
0.06\end{array}$ & $\begin{array}{c}0.94 \pm \\
0.02\end{array}$ & $\begin{array}{c}0.92 \pm \\
0.01\end{array}$ \\
\hline \multicolumn{13}{|l|}{$\begin{array}{l}\text { Non-essential } \\
\text { amino acids }\end{array}$} \\
\hline Alanine & $\begin{array}{l}0.47 \pm \\
0.05^{\mathrm{b}}\end{array}$ & $\begin{array}{c}0.64 \pm \\
0.04^{\mathrm{a}}\end{array}$ & $\begin{array}{c}0.46 \pm \\
0.04^{\mathrm{b}}\end{array}$ & $\begin{array}{c}0.41 \pm \\
0.02^{\mathrm{b}}\end{array}$ & $\begin{array}{l}4.67 \pm \\
0.19^{\mathrm{ab}}\end{array}$ & $\begin{array}{c}4.92 \pm \\
0.17^{\mathrm{a}}\end{array}$ & $\begin{array}{l}4.06 \pm \\
0.34^{\mathrm{ab}}\end{array}$ & $\begin{array}{c}3.65 \pm \\
0.40^{\mathrm{b}}\end{array}$ & $\begin{array}{c}5.33 \pm \\
0.49\end{array}$ & $\begin{array}{c}5.40 \pm \\
0.38\end{array}$ & $\begin{array}{c}5.53 \pm \\
0.49\end{array}$ & $\begin{array}{c}5.12 \pm \\
0.29\end{array}$ \\
\hline Glycine & $\begin{array}{c}0.37 \pm \\
0.03\end{array}$ & $\begin{array}{c}0.45 \pm \\
0.013\end{array}$ & $\begin{array}{c}0.41 \pm \\
0.017\end{array}$ & $\begin{array}{c}0.38 \pm \\
0.037\end{array}$ & $\begin{array}{c}3.68 \pm \\
0.10\end{array}$ & $\begin{array}{c}3.95 \pm \\
0.08\end{array}$ & $\begin{array}{c}3.24 \pm \\
0.28\end{array}$ & $\begin{array}{c}3.07 \pm \\
0.37\end{array}$ & $\begin{array}{c}5.50 \pm \\
0.33\end{array}$ & $\begin{array}{c}6.69 \pm \\
0.86\end{array}$ & $\begin{array}{c}5.49 \pm \\
0.58\end{array}$ & $\begin{array}{c}5.51 \pm \\
0.39\end{array}$ \\
\hline
\end{tabular}




\begin{tabular}{|c|c|c|c|c|c|c|c|c|c|c|c|c|}
\hline Serine & $\begin{array}{c}0.44 \pm \\
0.06^{\mathrm{b}}\end{array}$ & $\begin{array}{c}0.89 \pm \\
0.04^{\mathrm{a}}\end{array}$ & $\begin{array}{c}0.47 \pm \\
0.04^{\mathrm{b}}\end{array}$ & $\begin{array}{c}0.41 \pm \\
0.03^{\mathrm{b}}\end{array}$ & $\begin{array}{c}3.61 \pm \\
0.17\end{array}$ & $\begin{array}{c}3.85 \pm \\
0.13\end{array}$ & $\begin{array}{c}3.28 \pm \\
0.30\end{array}$ & $\begin{array}{c}2.91 \pm \\
0.35\end{array}$ & $\begin{array}{c}4.85 \pm \\
0.36\end{array}$ & $\begin{array}{c}5.56 \pm \\
0.73\end{array}$ & $\begin{array}{c}4.79 \pm \\
0.28\end{array}$ & $\begin{array}{c}4.87 \pm \\
0.36\end{array}$ \\
\hline Proline & $\begin{array}{l}0.49 \pm \\
0.05^{\mathrm{ab}}\end{array}$ & $\begin{array}{c}0.61 \pm \\
0.02^{\mathrm{a}}\end{array}$ & $\begin{array}{l}0.50 \pm \\
0.03^{\mathrm{ab}}\end{array}$ & $\begin{array}{c}0.42 \pm \\
0.02^{\mathrm{b}}\end{array}$ & $\begin{array}{c}4.45 \pm \\
0.19^{\mathrm{ab}}\end{array}$ & $\begin{array}{c}4.91 \pm \\
0.12^{\mathrm{a}}\end{array}$ & $\begin{array}{l}4.09 \pm \\
0.35^{\mathrm{ab}}\end{array}$ & $\begin{array}{c}3.66 \pm \\
0.48^{b}\end{array}$ & $\begin{array}{c}4.78 \pm \\
0.60\end{array}$ & $\begin{array}{c}4.95 \pm \\
0.58\end{array}$ & $\begin{array}{c}5.10 \pm \\
0.78\end{array}$ & $\begin{array}{c}4.46 \pm \\
0.49\end{array}$ \\
\hline Aspartic acid & $\begin{array}{c}0.87 \pm \\
0.13\end{array}$ & $\begin{array}{c}0.97 \pm \\
0.11\end{array}$ & $\begin{array}{c}0.80 \pm \\
0.09\end{array}$ & $\begin{array}{c}0.67 \pm \\
0.09\end{array}$ & $\begin{array}{l}7.45 \pm \\
0.32^{\mathrm{ab}}\end{array}$ & $\begin{array}{c}7.93 \pm \\
0.23^{\mathrm{a}}\end{array}$ & $\begin{array}{l}6.54 \pm \\
0.60^{\mathrm{ab}}\end{array}$ & $\begin{array}{c}5.73 \pm \\
0.32^{\mathrm{b}}\end{array}$ & $\begin{array}{c}6.76 \pm \\
1.57\end{array}$ & $\begin{array}{c}6.03 \pm \\
1.61\end{array}$ & $\begin{array}{c}6.96 \pm \\
1.44\end{array}$ & $\begin{array}{c}5.95 \pm \\
1.30\end{array}$ \\
\hline Glutamic acid & $\begin{array}{c}0.89 \pm \\
0.13^{\mathrm{b}}\end{array}$ & $\begin{array}{c}1.56 \pm \\
0.20^{\mathrm{a}}\end{array}$ & $\begin{array}{c}0.90 \pm \\
0.09^{\mathrm{b}}\end{array}$ & $\begin{array}{c}0.81 \pm \\
0.13^{\mathrm{b}}\end{array}$ & $\begin{array}{c}7.45 \pm \\
0.34\end{array}$ & $\begin{array}{c}7.85 \pm \\
0.24\end{array}$ & $\begin{array}{c}6.71 \pm \\
0.56\end{array}$ & $\begin{array}{c}6.13 \pm \\
0.70\end{array}$ & $\begin{array}{c}8.82 \pm \\
1.73\end{array}$ & $\begin{array}{c}8.49 \pm \\
1.84\end{array}$ & $\begin{array}{c}8.96 \pm \\
1.75\end{array}$ & $\begin{array}{c}8.27 \pm \\
1.55\end{array}$ \\
\hline Tyr & $\begin{array}{c}0.25 \pm \\
0.02\end{array}$ & $\begin{array}{c}0.28 \pm \\
0.02\end{array}$ & $\begin{array}{c}0.25 \pm \\
0.02\end{array}$ & $\begin{array}{c}0.22 \pm \\
0.02\end{array}$ & $\begin{array}{c}2.93 \pm \\
0.10^{\mathrm{a}}\end{array}$ & $\begin{array}{c}3.09 \pm \\
0.08^{\mathrm{a}}\end{array}$ & $\begin{array}{l}2.57 \pm \\
0.23^{\mathrm{ab}}\end{array}$ & $\begin{array}{c}2.03 \pm \\
0.27^{\mathrm{b}}\end{array}$ & $\begin{array}{c}4.01 \pm \\
0.33\end{array}$ & $\begin{array}{c}4.34 \pm \\
0.26\end{array}$ & $\begin{array}{c}4.42 \pm \\
0.36\end{array}$ & $\begin{array}{c}4.19 \pm \\
0.32\end{array}$ \\
\hline Cysteine & $\begin{array}{c}1.04 \pm \\
0.07\end{array}$ & $\begin{array}{c}1.11 \pm \\
0.06\end{array}$ & $\begin{array}{c}0.99 \pm \\
0.08\end{array}$ & $\begin{array}{c}0.75 \pm \\
0.09\end{array}$ & $\begin{array}{l}1.04 \pm \\
0.07^{\mathrm{ab}}\end{array}$ & $\begin{array}{c}1.11 \pm \\
0.06^{\mathrm{a}}\end{array}$ & $\begin{array}{l}0.99 \pm \\
0.08^{\text {ab }}\end{array}$ & $\begin{array}{c}0.75 \pm \\
0.09^{\mathrm{b}}\end{array}$ & $\begin{array}{c}0.91 \pm \\
0.02\end{array}$ & $\begin{array}{c}0.89 \pm \\
0.04\end{array}$ & $\begin{array}{c}0.88 \pm \\
0.01\end{array}$ & $\begin{array}{c}0.85 \pm \\
0.01\end{array}$ \\
\hline Ornithine & ND & ND & ND & ND & $\begin{array}{c}0.19 \pm \\
0.01^{\mathrm{a}}\end{array}$ & $\begin{array}{c}0.21 \pm \\
0.01^{\mathrm{a}}\end{array}$ & $\begin{array}{c}0.19 \pm \\
0.01^{\mathrm{a}}\end{array}$ & $\begin{array}{c}0.15 \pm \\
0.01^{\mathrm{b}}\end{array}$ & $\begin{array}{c}0.46 \pm \\
0.18\end{array}$ & $\begin{array}{c}0.50 \pm \\
0.17\end{array}$ & $\begin{array}{c}0.59 \pm \\
0.24\end{array}$ & $\begin{array}{c}0.51 \pm \\
0.17\end{array}$ \\
\hline
\end{tabular}

ND; not detected

Values are mean \pm SEM of $\mathrm{n}=8$ rats/group. Different superscript letters a and $\mathrm{b}$ within the same row indicate significant difference at $p<0.05$ by One-way ANOVA followed by Tukey's test 
Table 4. Body composition of female rats fed $10 \%$ protein diets consisting of carp sarcoplasmic protein, casein, whey protein isolate, or 2 weeks on $10 \%$ casein diet followed by a no-protein diet.

\begin{tabular}{|c|c|c|c|c|}
\hline Tissue & CSP & Casein & WPI & No-Protein \\
\hline \multicolumn{5}{|l|}{ Wet Weight (g) } \\
\hline Liver & $8.45 \pm 0.47^{\mathrm{a}}$ & $8.48 \pm 0.35^{\mathrm{a}}$ & $9.54 \pm 0.52^{\mathrm{a}}$ & $5.4 \pm 0.19^{b}$ \\
\hline Gastrocnemius Muscles & $0.95 \pm 0.03^{\mathrm{a}}$ & $0.96 \pm 0.05^{\mathrm{a}}$ & $1.08 \pm 0.07^{\mathrm{a}}$ & $0.73 \pm 0.05^{\mathrm{b}}$ \\
\hline Soleus Muscles & $0.47 \pm 0.03^{\mathrm{ab}}$ & $0.52 \pm 0.02^{\mathrm{a}}$ & $0.41 \pm 0.03^{\mathrm{ab}}$ & $0.48 \pm 0.02^{\mathrm{b}}$ \\
\hline Gonadal Fat Pad & $2.62 \pm 0.46^{\mathrm{b}}$ & $3.26 \pm 0.53^{\mathrm{ab}}$ & $5.10 \pm 0.68^{a}$ & $1.47 \pm 0.35^{\mathrm{b}}$ \\
\hline Retroperitoneal Fat Pad & $1.85 \pm 0.48^{\mathrm{ab}}$ & $1.66 \pm 0.44^{\mathrm{ab}}$ & $2.22 \pm 0.39^{\mathrm{a}}$ & $0.30 \pm 0.08^{b}$ \\
\hline Right Kidney & $0.88 \pm 0.03^{\mathrm{a}}$ & $0.82 \pm 0.02^{\mathrm{a}}$ & $0.93 \pm 0.03^{\mathrm{a}}$ & $0.59 \pm 0.04^{\mathrm{b}}$ \\
\hline Left Kidney & $0.89 \pm 0.02^{\mathrm{ab}}$ & $0.82 \pm 0.02^{\mathrm{b}}$ & $0.95 \pm 0.03^{\mathrm{a}}$ & $0.65 \pm 0.05^{\mathrm{c}}$ \\
\hline Heart & $0.89 \pm 0.03^{\mathrm{a}}$ & $0.97 \pm 0.09^{\mathrm{a}}$ & $0.93 \pm 0.04^{\mathrm{a}}$ & $0.63 \pm 0.03^{b}$ \\
\hline Lungs & $1.45 \pm 0.08^{\mathrm{ab}}$ & $1.42 \pm 0.08^{\mathrm{ab}}$ & $1.51 \pm 0.06^{\mathrm{a}}$ & $1.20 \pm 0.08^{\mathrm{b}}$ \\
\hline Brain & $1.79 \pm 0.04$ & $1.62 \pm 0.05$ & $1.73 \pm 0.09$ & $1.72 \pm 0.04$ \\
\hline Adrenals & $0.94 \pm 0.33^{\mathrm{ab}}$ & $0.67 \pm 0.24^{\mathrm{ab}}$ & $1.38 \pm 0.39^{\mathrm{a}}$ & $0.21 \pm 0.06^{\mathrm{b}}$ \\
\hline Thymus & $0.64 \pm 0.07^{\mathrm{a}}$ & $0.61 \pm 0.04^{\mathrm{a}}$ & $0.61 \pm 0.09^{\mathrm{a}}$ & $0.35 \pm 0.04^{\mathrm{b}}$ \\
\hline Spleen & $0.43 \pm 0.02^{\mathrm{a}}$ & $0.46 \pm 0.02^{\mathrm{a}}$ & $0.52 \pm 0.03^{\mathrm{a}}$ & $0.27 \pm 0.02^{\mathrm{b}}$ \\
\hline
\end{tabular}

Values expressed as mean \pm SEM of $n=8$ rats/group. Different superscript letters a and $b$ within the same row indicate significant difference at $p<0.05$ by One-way ANOVA followed by Tukey's test. 
Table 5. Measurements of kidney and bone health in female rats fed 10\% protein diets consisting of carp sarcoplasmic protein, casein, whey protein isolate, or 2 weeks on $10 \%$ casein diet followed by a no-protein diet.

\begin{tabular}{|c|c|c|c|c|}
\hline & CSP & Casein & WPI & No-Protein \\
\hline \multicolumn{5}{|l|}{ Kidney Health Markers } \\
\hline Urinary Calcium Excretion (mg/week) & $9.93 \pm 3.95$ & $21.72 \pm 6.01$ & $24.07 \pm 8.36$ & $10.19 \pm 2.36$ \\
\hline Kidney Total Calcium (mg/g) & $0.36 \pm 0.03^{\mathrm{b}}$ & $0.45 \pm 0.01^{\mathrm{ab}}$ & $0.46 \pm 0.02^{\mathrm{ab}}$ & $0.56 \pm 0.04^{\mathrm{a}}$ \\
\hline \multicolumn{5}{|l|}{ Serum } \\
\hline Blood Urea Nitrogen (mg/dL) & $9.63 \pm 1.55$ & $11.50 \pm 0.65$ & $11.53 \pm 2.09$ & $10.01 \pm 1.13$ \\
\hline Calcium $(\mathrm{mg} / \mathrm{dL})$ & $9.30 \pm 0.43^{\mathrm{ab}}$ & $10.50 \pm 0.55^{\mathrm{a}}$ & $10.48 \pm 0.33^{\mathrm{a}}$ & $8.51 \pm 0.43^{\mathrm{b}}$ \\
\hline Albumin $(\mathrm{g} / \mathrm{dL})$ & $4.11 \pm 0.16^{\mathrm{a}}$ & $4.16 \pm 0.28^{\mathrm{a}}$ & $4.19 \pm 0.49^{\mathrm{a}}$ & $2.63 \pm 0.17^{\mathrm{b}}$ \\
\hline Creatinine (mg/dL) & $1.45 \pm 0.05$ & $1.40 \pm 0.08$ & $1.39 \pm 0.05$ & $1.53 \pm 0.11$ \\
\hline \multicolumn{5}{|l|}{ Bone Health Markers } \\
\hline \multicolumn{5}{|l|}{ Morphometry } \\
\hline Femoral Length (mm) & $27 \pm 0.16^{\mathrm{a}}$ & $26 \pm 0.57^{\mathrm{a}}$ & $26 \pm 0.56^{\mathrm{a}}$ & $22 \pm 0.92^{\mathrm{b}}$ \\
\hline Femoral Width (mm) & $3.8 \pm 0.04^{\mathrm{a}}$ & $3.7 \pm 0.06^{\mathrm{a}}$ & $3.8 \pm 0.04^{\mathrm{a}}$ & $3.5 \pm 0.05^{\mathrm{b}}$ \\
\hline Femoral Depth (mm) & $2.8 \pm 0.04^{\mathrm{a}}$ & $2.8 \pm 0.04^{\mathrm{a}}$ & $2.8 \pm 0.04^{\mathrm{ab}}$ & $2.6 \pm 0.04^{b}$ \\
\hline Femoral Dry weight (g) & $0.549 \pm 0.01^{\mathrm{a}}$ & $0.51 \pm 0.03^{\mathrm{a}}$ & $0.491 \pm 0.03^{\mathrm{a}}$ & $0.363 \pm 0.03^{\mathrm{b}}$ \\
\hline \multicolumn{5}{|l|}{ Mineralization } \\
\hline Femoral Total Mineral Content (mg/bone) & $190.27 \pm 3.17^{\mathrm{a}}$ & $178.46 \pm 8.21^{\mathrm{a}}$ & $173.96 \pm 8.12^{\mathrm{a}}$ & $128.80 \pm 7.53^{\mathrm{b}}$ \\
\hline Femoral Total Calcium (mg/g bone) & $123.63 \pm 2.59$ & $127.22 \pm 3.90$ & $129.99 \pm 3.12$ & $129.73 \pm 4.36$ \\
\hline Femoral Total Phosphorous (mg/g bone) & $73.42 \pm 1.21$ & $73.57 \pm 1.24$ & $77.18 \pm 1.44$ & $75.76 \pm 2.08$ \\
\hline \multicolumn{5}{|l|}{ Bone Strength } \\
\hline Femoral Peak Force $(\mathrm{N})$ & $126.68 \pm 4.39$ & $129.01 \pm 6.40$ & $137.98 \pm 4.29$ & $117.00 \pm 7.08$ \\
\hline \multicolumn{5}{|l|}{ Femoral Ultimate Bending Stress } \\
\hline$(\mathrm{N} / \mathrm{mm} 2)$ & $38.41 \pm 1.37$ & $38.88 \pm 2.71$ & $42.18 \pm 1.48$ & $35.65 \pm 2.78$ \\
\hline Ultimate Stiffness (N/s) & $440.46 \pm 20.06$ & $465.25 \pm 21.45$ & $459.95 \pm 15.89$ & $392.550 \pm 33.44$ \\
\hline Young's Modulus (N/mm2) & $2415.09 \pm 124.99$ & $2412.66 \pm 140.52$ & $2253.64 \pm 127.73$ & $1985.59 \pm 239.67$ \\
\hline
\end{tabular}

Values expressed as mean \pm SEM of $n=5-8$ rats/group. Different superscript letters a and $b$ within the same row indicate significant difference at $p<0.05$ by One-way ANOVA followed by Tukey's test. 


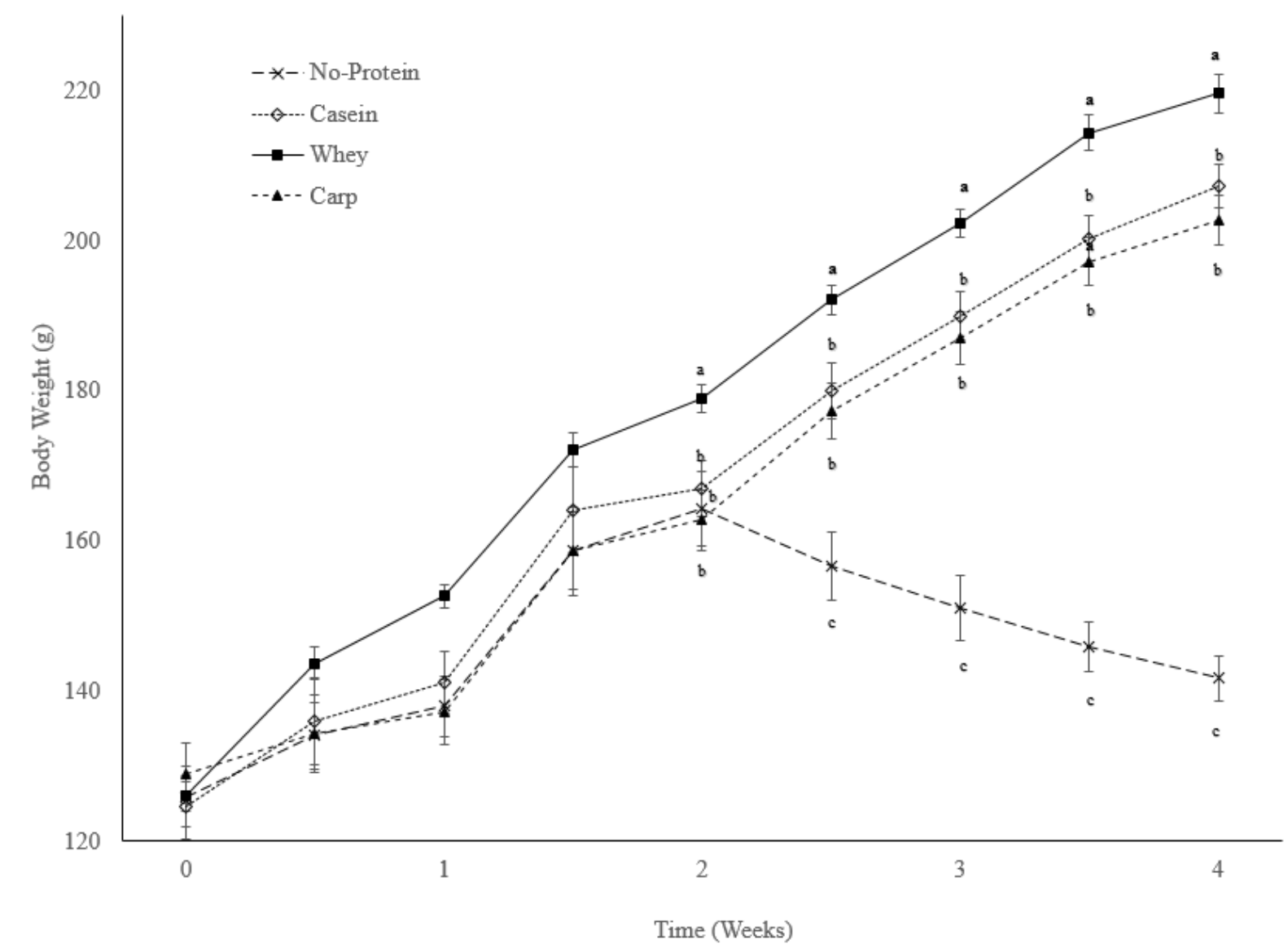

Figure 1: Body weights of female rats fed $10 \%$ protein diets consisting of carp sarcoplasmic protein, casein, whey protein isolate, or 2 weeks on $10 \%$ casein diet followed by a no-protein diet. Values are mean \pm SEM of $n=8$ rats/group. Letters (a, b, c) shows significant difference at $p<0.05$ determined by ANOVA followed by Tukey's HSD. 


\section{Supplemental Tables}

Supplemental Table 1: Body composition corrected for body weight of female rats fed $10 \%$ protein diets consisting of casein, whey protein isolate, carp sarcoplasmic protein, or 2 weeks on $10 \%$ casein diet followed by a no-protein diet.

\begin{tabular}{|c|c|c|c|c|}
\hline Tissue & CSP & Casein & WPI & $\begin{array}{l}\text { No- } \\
\text { protein }\end{array}$ \\
\hline \multicolumn{5}{|c|}{$\begin{array}{l}\text { Relative Weight (g tissue/g body } \\
\text { weight) }\end{array}$} \\
\hline Liver & $4.15 \pm 0.18$ & $4.10 \pm 0.14$ & $\begin{array}{l}4.18 \pm \\
0.17\end{array}$ & $\begin{array}{l}3.89 \pm \\
0.15\end{array}$ \\
\hline Gastrocnemius Muscles & $0.47 \pm 0.02$ & $0.46 \pm 0.03$ & $\begin{array}{l}0.49 \pm \\
0.03\end{array}$ & $\begin{array}{l}0.48 \pm \\
0.02\end{array}$ \\
\hline Soleus Muscles & $0.23 \pm 0.01$ & $0.26 \pm 0.01$ & $0.22 \pm .01$ & $\begin{array}{l}0.25 \pm \\
0.02\end{array}$ \\
\hline Gonadal Fat Pad & $\begin{array}{l}1.28 \pm \\
0.22^{\mathrm{b}}\end{array}$ & $\begin{array}{l}1.57 \pm \\
0.25^{\mathrm{ab}}\end{array}$ & $\begin{array}{l}2.31 \pm \\
0.31^{\mathrm{a}}\end{array}$ & $\begin{array}{l}1.06 \pm \\
0.25^{\mathrm{b}}\end{array}$ \\
\hline Retroperitoneal Fat Pad & $\begin{array}{l}0.91 \pm \\
0.24^{\mathrm{ab}}\end{array}$ & $\begin{array}{l}0.80 \pm \\
0.22^{\mathrm{ab}}\end{array}$ & $\begin{array}{l}1.01 \pm \\
0.18^{\mathrm{a}}\end{array}$ & $\begin{array}{l}0.28 \pm \\
0.05^{\mathrm{b}}\end{array}$ \\
\hline Right Kidney & $0.43 \pm 0.01$ & $0.4 \pm 0.01$ & $\begin{array}{l}0.43 \pm \\
0.02\end{array}$ & $\begin{array}{l}0.39 \pm \\
0.02\end{array}$ \\
\hline Left Kidney & $0.44 \pm 0.01$ & $0.40 \pm 0.01$ & $\begin{array}{l}0.43 \pm \\
0.01\end{array}$ & $\begin{array}{l}0.41 \pm \\
0.02\end{array}$ \\
\hline Heart & $0.45 \pm 0.02$ & $0.47 \pm 0.01$ & $\begin{array}{l}0.42 \pm \\
0.02\end{array}$ & $\begin{array}{l}0.46 \pm \\
0.02\end{array}$ \\
\hline Lungs & $0.76 \pm 0.05$ & $0.69 \pm 0.03$ & $\begin{array}{l}0.72 \pm \\
0.04\end{array}$ & $\begin{array}{l}0.86 \pm \\
0.06\end{array}$ \\
\hline Brain & $\begin{array}{l}0.88 \pm \\
0.02^{\mathrm{b}}\end{array}$ & $0.79 \pm 0.03^{\mathrm{b}}$ & $\begin{array}{l}0.84 \pm \\
0.06^{\mathrm{b}}\end{array}$ & $\begin{array}{l}1.19 \pm \\
0.05^{\mathrm{a}}\end{array}$ \\
\hline Adrenals & $0.01 \pm 0.01$ & $0.01 \pm 0.01$ & $\begin{array}{l}0.01 \pm \\
0.01\end{array}$ & $\begin{array}{l}0.01 \pm \\
0.01\end{array}$ \\
\hline Thymus & $0.32 \pm 0.03$ & $0.30 \pm 0.02$ & $\begin{array}{l}0.28 \pm \\
0.04\end{array}$ & $\begin{array}{l}0.25 \pm \\
0.03\end{array}$ \\
\hline Spleen & $0.21 \pm 0.19$ & $0.22 \pm 0.01$ & $\begin{array}{l}0.24 \pm \\
0.01\end{array}$ & $\begin{array}{l}0.20 \pm \\
0.02\end{array}$ \\
\hline
\end{tabular}

Values expressed as mean \pm SEM of $\mathrm{n}=8$ rats/group. Different superscript letters a and $\mathrm{b}$ within the same row indicate significant difference at $p<0.05$ by One-way ANOVA followed by Tukey's test 


\section{Chapter V}

Feeding Growing Rats a Low Protein Diet Comprised of Silver Carp (Hypophthalmichthys molitrix) has Minimal Effects on Growth, Adipose, and Hepatic Lipid Metabolism

Derek Warren ${ }^{1}$, David J. Laub ${ }^{2}$, R. Chris Skinner ${ }^{3}$, Kristen Matak ${ }^{1}$, Vagner A. Benedito ${ }^{4}$, Janet
C. Tou

${ }^{1}$ Division of Animal and Nutritional Sciences, ${ }^{2}$ Department of Biology, ${ }^{4}$ Division of Plant and

Soil Sciences, West Virginia University, Morgantown, WV

${ }^{3}$ Health Sciences Department, University of the Ozarks, Clarksville, AR

*Corresponding Author:

Janet C. Tou, PhD, P.O. Box 6108, Animal and Nutritional Sciences, West Virginia University, Morgantown, WV 26506, USA.

Phone: (304)293-1919; Fax: (304)293-2232

e-mail: janet.tou@mail.wvu.edu

Choice of journal where article should appear: Nutrients 


\begin{abstract}
Consumption of high protein, milk-based infant formulas have been reported to increase body weight gain and later life obesity risk resulting in the recommendation to lower protein content. However, protein deficiency has been characterized by stunting and fatty liver due to altered liver lipid metabolism. The objective of this study was to assess the effect low protein diets from different sources on hepatic and adipose tissue lipid metabolism compared to a protein deficient diet. Young (age 28 days) female Sprague-Dawley rats were randomly assigned ( $\mathrm{n}=8$ rats/group) to standard purified diet with $10 \%$ kcal protein as casein, whey protein, carp sarcoplasm protein (CSP) or a protein deficient diet. Results showed whey-fed rats had the greatest $(\mathrm{p}<0.05)$ body weight and adiposity; however, there were no differences in gene markers of lipogenesis, lipolysis or triglyceride synthesis and transport in adipose tissue. Caseinfed rats showed an anti-inflammatory response in adipose tissue indicated by upregulation of ( $p$ $<0.05)$ of COX-2 and interleukin-10. Hepatic histology showed greater $(\mathrm{p}<0.05)$ hepatic fat infiltration were observed in rats fed the protein deficient diet while no differences in fat infiltration among rats consuming CSP, casein or whey. Hepatic lipoprotein lipase (LPL) of casein-fed rats was the only significantly $(\mathrm{p}<0.05)$ altered biomarker in response to adipose interleukin-10 production. Collectively, results indicate lower protein diets containing CSP and casein is a physiologically safe option and may be preferable to whey protein for preventing increased adiposity and with minimal alterations to gene expression.
\end{abstract}




\section{Introduction}

Global fisheries currently operating close to maximal levels are at risk depleting fish stocks (FAO, 2016). According to the Fishes and Aquaculture Organization (FAO), expansion of aquaculture industries decreased by $3.3 \%$, while the global human populations is expected to increase to 10 billion by 2050 (FAO, 2016). A potential solution to ensure fisheries sustainability is to promote use of less desirable fish species and fish processing by-products.

Silver carp (Hypophthalmichthys molitrix) was imported into the United States in the 1970s to control algal growth in aquaculture and for sewage treatment ponds. Due to unintentional introduction into the wild, carp has become an invasive species spreading into various habitats and disrupting existing ecosystems (Chick 2001). Despite its abundance, silver carp are underutilized as a food source due to their boniness making consumption and processing into edible products difficult. A proposed solution to the problem of this invasive fish species is to develop carp into a protein supplement for human consumption. Previous research investigated the recovery of sarcoplasm protein from carp wash water and in vitro characteristics of the resulting protein-rich silver carp sarcoplasmic protein powder (CSP) (Warren et al. 2018). Subsequently, an animal feeding study showed CSP powder protein quality, bioavailability, growth, and safety were comparable to commercially popular milk proteins, casein and whey protein isolate (Warren et al., 2020).

Although, casein and whey protein have been used in infant formulas with long-term commercial success compared to human milk, infant formulas often have higher protein content (Tang, 2018). Higher body weight gains are common in formula-fed infants and has been attributed to the higher protein content (Ong et al., 2009). This is a health concern since weight gain during the first year of life has been suggested to be one of the strongest indicators of future 
risk of obesity (Ong \& Loos, 2006). Previous research has reported whey-based formulas promoted greater body weight gains by enhancing hepatic insulin like growth factor 1 (IGF-1) secretion which mediates lipid synthesis in adipose tissue (Ong et al.,2009; O'Connell, 2013). However, by lowering protein content of infant formulas this may be detrimental to growth and liver function.

Protein-energy malnutrition is defined as an imbalance between intake of protein and energy and the amount required for optimal growth, development, and function (Fock et al., 2010; Bossola, 2015). Protein-energy malnutrition has been reported to alter liver histology and biochemical characteristics (Caballero et al., 2015; Feres et al., 2010). Gomes and others (2017) reported reduced liver weight and hepatocyte volume in protein undernourished mice. Further, protein energy malnutrition has been characterized by fatty liver and hepatic dysfunction (Zutphen et al., 2016). When the quantity of dietary protein is reduced, protein quality and digestibility becomes more important for sustaining growth and metabolic function. Koletzko and others (2009) reported infants fed diets containing high quality proteins in lower amounts supported normal growth while reducing the risk of obesity development later in life.

The protein composition of wild carp was found to be $16.69 \%$ and to contain all 10 essential amino acids in quantities required for human needs (Ljubojević, 2017). Additionally, marine derived proteins have been suggested to lower cardiovascular risk. An animal feeding study found marine proteins reduced total serum cholesterol compared to casein by increased cholesterol and bile acid fecal excretion (Narayan et al., 2009). Fish protein derived from cod was found to lower liver triglyceride content and secretion compared to casein (Demonty et al., 2003). In addition to its protein content, wild carp can have $7.13 \%$ lipid content with $72.64 \%$ of fatty acids consisting of polyunsaturated fatty acids (PUFAs) with health-beneficial omega-3 
PUFAs ( $\omega-3$ PUFAs) being particularly abundant at 5.97\% (Ljubojević, 2017). Omega-3 PUFAs are often added to infant formulas for infant growth and development of visual and cognitive function (Gil et al., 2003). Further, $\omega$-3 PUFA supplementation has been reported to improved fatty liver and hepatic dysfunction clinical markers in a meta-analysis of 18 studies consisting of 1,424 patients.

The objective of this study was to assess the effect of providing a low protein diet (10\% kcal) consisting of CSP or commercial milk protein powders, whey and casein, on lipid metabolism in liver and adipose tissue compared to a protein deficient diet using a rat model. We hypothesize a low protein diet comprised of CSP will alter lipid metabolism resulting in reduced adiposity and hepatic lipid accumulation compared to casein and whey protein.

\section{Materials and Methods}

\subsection{Animals and Diets}

All animal procedures were approved by West Virginia University's Animal Care and Use Committee and performed in accordance with National Research Council for the Care and Use of Laboratory Animals Guidelines (National Research Council 1996). Immature (age 28 days) female Sprague-Dawley rats $(\mathrm{n}=32)$ were purchased from Charles River (Worcester, MA) and individually housed in metabolic cages for the duration of the four weeks study. Following 7-day acclimation, rats $(\mathrm{n}=32)$ were randomly assigned to four diet treatment groups $(n=8$ rats/group) consisting of purified standard rodent diet AIN-93G (American Institute of Nutrition93Growth) containing 10\% kcal protein from different sources: (1) CSP for 4 weeks, (2) casein for 4 weeks, (3) whey protein isolate for 4 weeks or, (4) a protein deficient diets comprised of AIN-93G with $10 \% \mathrm{kcal}$ casein for 2 weeks followed by protein deficient diet for the remaining 
2 weeks. Diet ingredients and composition are provided in Table 1. All experimental diets were adjusted to be isocaloric $(3.7-3.8 \mathrm{kcal} / \mathrm{g})$.

Following establishment of a standard average food intake, rats were peer fed. To avoid difference in caloric intake, rats were provided $16 \pm 0.2 \mathrm{~g}$ diet daily. All diets and proteins, casein and whey protein isolate were purchased from Envigo-Teklad (Madison, WI). Diets were stored at $-20^{\circ} \mathrm{C}$ until fed. Rats were provided deionized, distilled water $\left(\mathrm{ddH}_{2} \mathrm{O}\right)$ ad libitum. Body weight and $\mathrm{ddH}_{2} \mathrm{O}$ intake were measured weekly.

Following 4 weeks of feeding, rats were fasted overnight (12 h) and euthanized via carbon dioxide inhalation. Liver and gonadal fat pad were dissected. Tissues were weighed, flash frozen in liquid nitrogen, and stored at $-80^{\circ} \mathrm{C}$ for later analysis.

\subsection{Diet and Tissue Lipid Content}

Lipids were extracted from the experimental diets and tissues according to methods described by Bligh and Dyer (1959). Briefly, experimental diets (1.0g) liver tissue (1.0g) and gonadal adipose tissue $(0.5 \mathrm{~g})$ were homogenized in Tris/EDTA buffer (pH 7.4). Nonadecanoic acid $(50 \mu \mathrm{L})$ was added as an internal standard for fatty acid quantification followed by the addition of a chloroform: methanol: acetic acid solution $(2: 1: 0.15, \mathrm{v} / \mathrm{v} / \mathrm{v})$. Samples were centrifuged at $900 \times \mathrm{g}$ for 10 minutes at $10^{\circ} \mathrm{C}$, and the chloroform layer (bottom layer) was collected and filtered. The filtered chloroform layer was mixed with a chloroform:methanol solution $(4: 1, v / v)$, centrifuged at $900 \times \mathrm{g}$ for 10 minutes at $10^{\circ} \mathrm{C}$, and the resulting chloroform layer was collected and filtered. Extracted lipids were dried under nitrogen gas and total lipid content was determined gravimetrically.

\subsection{Diet and Tissue Fatty Acid Composition}


Following lipid extraction, fatty acids were transmethylated as described by Fritsche and Johnston (1990). Briefly, fatty acids were methylated by adding a solution of $4 \%$ sulfuric acid in anhydrous methanol to samples of extracted lipids. Samples were incubated for 60 minutes in a $90^{\circ} \mathrm{C}$ water bath, cooled to room temperature, and then the reaction was stopped using $\mathrm{ddH}_{2} \mathrm{O}$. Chloroform was added to the methylated samples and centrifuged at $900 \mathrm{x} \mathrm{g}$ for 10 minutes at $10^{\circ} \mathrm{C}$. To remove remaining water, the collected chloroform layer was filtered through anhydrous sodium sulfate. Fatty acid methyl esters (FAMEs) were dried under nitrogen gas, resuspended in isooctane, and stored at $-20^{\circ} \mathrm{C}$ until analysis.

Fatty acid methyl esters (FAMEs) were analyzed using gas liquid chromatography (CP3800; Varian, Walnut Creek, CA, USA). This involved an initial temperature of $140^{\circ} \mathrm{C}$ for 5 minutes increased by $1^{\circ} \mathrm{C}$ per minute to a final temperature of $220^{\circ} \mathrm{C}$. FAMEs were separated with a wall-coated open tubular fused silica capillary column (Varian, Walnut Creek, CA, USA) with a CP-Sil 88 stationary phase and a nitrogen carrier gas. Total separation time was 56 minutes. To identify fatty acids, quantitative 37 Component FAMEs Sigma Mix (Supelco, Bellefonte, PA) was used. Fatty acid identities were determined by retention time, quantified using peak area counts, and reported as percent of total fatty acids.

\subsection{Liver Histology}

The left lateral lobe of the liver $(\mathrm{n}=3)$ was removed and placed in $10 \%$ buffered formalin for histology analysis. Extracted tissues were dehydrated with solutions of increasing ethanol concentration (70-100\%) in $\mathrm{ddH}_{2} \mathrm{O}$ then placed in xylene and embedded in paraffin. $8 \mu \mathrm{m}$ sections from each were stained with eosin and hematoxylin. Hepatic fat accumulation was graded using classification provided in Brunt, et al. (1999). Grade 0 indicated no presence of fat vacuoles, grade 1 indicated fat vacuole presence in less than $33 \%$ of hepatocytes, grade 2 
indicated presence in 33-66\% of hepatocytes, and grade 3 indicated evidence of fat vacuoles in greater than $66 \%$ of hepatocytes. Slides were analyzed with a Nikon TE 2000-S light microscope (Nikon Instruments, New York, NY) at 10x magnification by a trained investigator blinded to group identities. Images were captured using a PC interface with Q-Capture imaging software (Quantitative Imaging Corporation, BC, Canada).

\subsection{RNA isolation and gene expression}

Total RNA was extracted from frozen liver and gonadal adipose tissue using the Zymo Research mRNA Isolation Kit (Irvine, CA, USA) according to manufacturers' instructions. Isolated RNA was quantified by spectrophotometry (NanoDrop 100; Thermo Scientific, Waltham, MA, USA) and integrity was visualized on a $1.5 \%$ agarose gel. Isolated RNA was treated with DNase I with a TURBO DNA-free kit (Applied Biosystems, Foster City, CA, USA).

Real-time quantitative polymerase chain reaction (RT-qPCR) was used to amplify total mRNA using the Superscript III First-Strand Synthesis System with oligo dT primers for Carbohydrate-response element-binding protein (ChREBP), Sterol regulatory element-binding protein-1c (SREBP-1c), Sterol regulatory element-binding protein-2 (SREBP-2), fatty acid synthase (FAS), Stearoyl-CoA desaturase-1 (SCD-1), Peroxisome proliferator-activated receptor alpha (PPAR $\alpha$ ), peroxisome proliferator-activated receptor gamma (PPAR $\gamma$ ), hormone sensitive lipase (HSL), diacylglycerol O-acyltransferase 2 (DGAT2), lipoprotein lipase (LPL), microsomal triglyceride transfer protein (MTTP), cyclooxygenase 2 (COX-2), interleukin 10 (IL-10), and nuclear factor kappa-light-chain-enhancer of activated B cells (NFkB). House-keeping genes included $\beta$-actin and GAPDH (Invitrogen, Carlsbad, CA, USA). Primers were designed using the Primer3 program (Howard Hughes Medical Institute) and respective mRNA sequences from the NCBI database. Forward and reverse primers for gene transcription are provided in Table $\mathbf{1 .}$ 
RT-qPCR of liver and gonadal adipose tissues used 2.5 $\mu \mathrm{L}$ of SYBR Green Master Mix (Applied Biosystems, Foster City, CA, USA), $1 \mu \mathrm{L}$ of cDNA (diluted 1:10), $1 \mu \mathrm{L}$ of forward and

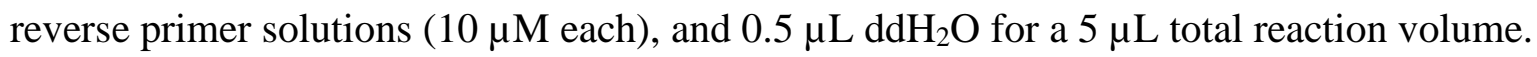
Thermal cycling included 2 minutes at $50^{\circ} \mathrm{C}, 10$ minutes at $95^{\circ} \mathrm{C}$, and then 40 cycles of 15 seconds at $95^{\circ} \mathrm{C}$ and 1 minute at $60^{\circ} \mathrm{C}$. A melt curve analysis was utilized following cycling.

\subsection{Serum Biochemical Markers}

Prior to euthanasia by carbon dioxide inhalation, rats were fasted overnight. Blood was collected by cardiac puncture and centrifuged at $1500 \times g$ at $4^{\circ} \mathrm{C}$ for $10 \mathrm{~min}$ to separate serum. Serum was collected and stored at $-80^{\circ} \mathrm{C}$ until analyzed. Alanine aminotransferase (ALT) and aspartate aminotransferase (AST) were measured to assess hepatic function by enzymatic colorimetric assays using a commercially available Vet- 16 rotor. Absorbance was measured at $595 \mathrm{~nm}$ by Hemagen Analyst automated spectrophotometer (Hemagen Diagnostics Inc., Columbia, MD).

A commercially available fluorometric assay (Cell Biolabs, San Diego, CA, USA) was used to determine serum total cholesterol (TC), low-density lipoprotein-cholesterol (LDL-C/VLDLC), and high-density lipoprotein-cholesterol (HDL-C). Briefly, serum $(200 \mu \mathrm{L})$ was mixed with precipitation reagent $(200 \mu \mathrm{L})$ and centrifuged for 20 minutes at $2000 \times g$. The HDL-C containing supernatant was collected and diluted (1:50) with reaction buffer. The LDL-C/VLDLC pellet was resuspended and diluted (1:50) with reaction buffer. Samples were transferred into a 96-well plate and incubated for 45 minutes. Excitation at $570 \mathrm{~nm}$ and emission at $590 \mathrm{~nm}$ was measured with a microplate reader (BioTek Instruments Inc., Winooski, VT).

A colorimetric assay purchased from Cayman Chemical (Ann Arbor, MI, USA) was used to determine serum triglycerides. Briefly, serum samples $(10 \mu \mathrm{L})$ were aliquoted in duplicate into 
a 96-well plate and mixed with $150 \mu \mathrm{L}$ of diluted enzyme solution to imitate the reaction.

Following bench top incubation for 45 minutes, absorbance at $540 \mathrm{~nm}$ was measured using a microplate reader (BioTek Instruments Inc., Winooski, VT).

\subsection{Statistical Analysis}

All results are expressed as mean \pm standard error of the mean $(\mathrm{SEM})$. Gene expression was analyzed as a function of mRNA abundance (A) using the following formula derived from Jacometo et al. (2014):

$$
A=1 \frac{1}{E_{\text {g.o.i }} C_{T, \text { g.o.i. }}-E_{\text {h.k. }} C_{T, h . k .}}
$$

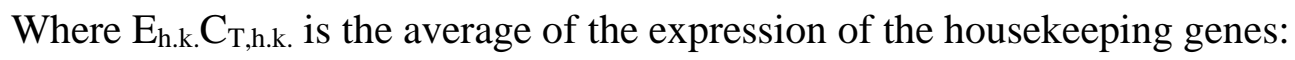

$$
E_{h . k .} C_{T, h . k .}=0.5\left(E_{G A P D H} C_{T, G A P D H}+E_{A C T B} C_{T, A C T B}\right)
$$

Data for each treatment group was log-transformed prior to statistical analysis and significant differences were determined by one-way analysis of variance (ANOVA). Post-hoc Tukey's test was used with $\mathrm{p}<0.05$ signifying statistically significance. Statistical analyses were performed using SAS JMP Pro 12.0 (SAS Institute Inc., NC, USA).

\section{Results}

\subsection{Fatty Acid Composition of Diets}

As shown in Table 2, fat content of all experimental diets was $\approx 7 \% \mathrm{kcal}$. The fatty acid profile of experimental diets is shown in Table 3. Palmitoleic acid (16:1) was present in the CSP diet, but not the other protein diets. There was no other significant difference in saturated fatty acid (SFAs), monounsaturated fatty acid (MUFAs), or essential fatty acid, linoleic acid and $\alpha$ linoleic acid, content between any of the experimental diets. Arachidonic acid, eicosapentaenoic acid, and docosahexaenoic acid were determined to be negligible in all experimental diets.

\subsection{Food Intake, Body Weight and Tissue Weight}


Feeding whey protein for 4 weeks resulted in greater $(\mathrm{p}<0.05)$ final body weight compared to CSP and casein. There were no body weight differences between the casein and CSP-fed rats. Body weight was significantly reduced in rats provided a protein deficient diet for two weeks (Figure 1). There were no differences in total diet intake and caloric intake among dietary protein groups. However, feed efficiency was significantly greater $(\mathrm{p}<0.05)$ in rats fed whey protein compared to rats fed CSP. Rats fed a protein deficient diet had the lowest $(\mathrm{p}<$ 0.05) feed efficiency (Table 4).

Rats fed whey protein had greater $(\mathrm{p}<0.05)$ gonadal fat pad weight compared to rats fed CSP and protein-free diet. Liver weight was significantly heavier $(\mathrm{p}<0.05)$ for rats fed $10 \%$ protein as CSP, casein, and whey protein compared to the protein deficient group. However, differences were no longer significant after corrected for body weight.

\subsection{Liver Histology}

Liver histology identified $<33 \%$ fat vacuoles in the hepatocytes in $100 \%$ of rats fed CSP compared to $33 \%$ of rats fed casein or whey protein. Greatest hepatic fat infiltration was observed in rats fed the protein deficient diet. In the protein deficient group, approximately $33 \%$ of rats showed 33-66\% fat vacuoles in hepatocytes and $66 \%$ showed fat vacuoles in $<66 \%$ of hepatocytes (Figure 3). There was an overall significant $(\mathrm{p}=0.0327)$ difference among histology scores.

\subsection{Liver Lipid Content and Fatty Acid Composition}

As shown in Table 5, rats fed the protein deficient diet had greater $(\mathrm{p}<0.05)$ total hepatic lipid content compared to rats fed $10 \%$ protein as either CSP, casein or whey-protein. Rats fed a protein deficient diet had the lowest hepatic stearic acid (18:0) content and the highest $(\mathrm{p}<0.05)$ hepatic oleic acid $(18: 1)$, linoleic acid and $\alpha$-linoleic content. The liver of rats fed 
protein deficient diet contained arachidonic acid $(0.14 \pm 0.03)$ but was negligible in the hepatic tissue of protein-fed rats. There were no differences $(p>0.05)$ in total lipid content and fatty acid composition among rats fed different protein sources.

\subsection{Hepatic Gene Expression}

As shown in Table 6, gene expression of hepatic LPL was upregulated $(\mathrm{p}<0.05)$ in rats consuming casein. Conversely, consumption of the protein deficient diet downregulated $(\mathrm{p}<$ 0.05) hepatic LPL expression. There were no differences in expression of genes involved in lipogenesis (ChREBP, SREBP-1c, SREBP-2, FAS, SCD-1), lipolysis (PPAR $\alpha$, PPAR $\gamma$, HSL) or expression of genes regulating triglyceride synthesis and transport (DGAT2, MTTP) or inflammation (COX-2, IL-10, NFאB).

\subsection{Adipose Lipid Content and Fatty Acid Composition}

Shown in Table 7, there was no significant difference in gonadal adipose tissue total lipid content or adipose tissue fatty acid composition among experimental diet groups.

\subsection{Adipose Gene Expression}

Shown in Table 8, there were no differences in expression of genes involved in lipogenesis (ChREBP, SREBP-1c, SREBP-2, FAS, SCD-1), lipolysis (PPAR $\alpha$, PPAR $\gamma$, HSL), or triglyceride synthesis and transport genes (DGAT2, LPL, MTTP) among the experimental diet groups. Adipose COX-2 expression was downregulated $(\mathrm{p}<0.05)$ in rats fed CSP and protein deficient diets. Gene expression of COX-2 was upregulated $(\mathrm{p}<0.05)$ in adipose tissue of rats consuming casein. Additionally, gene expression of IL-10 was upregulated $(p<0.05)$ in adipose tissue of rats fed casein diet. Adipose IL-10 expression was downregulated $(\mathrm{p}<0.05)$ in rats consuming protein deficient diet. There were no gene expression differences in inflammatory transcription factor (NFkB) among experimental diet groups. 


\subsection{Serum Liver Enzymes, Cholesterol, and Triglycerides}

Shown in Table 9, there were no significant differences in serum AST, ALT among experimental diet groups. There were also no significant differences in serum triglycerides, total cholesterol, HDL-C, and VLDL/LDL-C among experimental diet groups.

\section{Discussion}

\subsection{Growth Parameters}

As expected, growing rat fed the protein deficient ( $0 \%$ kcals) diet for 2 weeks had the lowest body weight. Growing rats fed a low $(10 \% \mathrm{kcal})$ protein diet derived from either fish or dairy sources supported growth within the normal range according to the body weight chart for female Sprague-Dawley provided by the animal vendor (Charles River, Worcester, MA). However, rats fed whey protein had significantly heavier final body weights and gonadal adipose compared to rats fed CSP despite no differences in caloric intake. Feeding growing rats $20 \% \mathrm{kcal}$ protein diets, Liaset and others (2009) reported higher body weight gain, but no differences in adipose tissue weight in rats fed casein compared to fish protein. Whey protein was not investigated. In the current study, higher gonadal adipose $(\mathrm{p}<0.05)$ in rats fed whey protein compared to CSP may be due to higher feed efficiency. Whey proteins remain soluble in the stomach and pass rapidly into the intestine leading rapid delivery rates for peptides and amino acids (Boirie et al., 1997). However, high whey protein intake has been suggested to contribute weight gain in early life. Early weight gain has been reported to be one of the best indicators of later risk of obesity (Ong \& Loos, 2006).

In the current study, diets were isocaloric and nutrients were adjusted to have no differences in dietary lipid content or fatty acid composition between experimental diets: therefore, phenotypic differences were due to differences in protein sources. Amino acid analysis 
of our diets showed whey protein had the highest leucine and isoleucine content (Warren et al., 2020). Branch chain amino acids have been reported to promote adipogenesis by stimulating insulin and insulin like growth factor-1 (IGF-1) (Melnik, 2012). Additionally, leucine and isoleucine play an important role in the synthesis of proteins and other nitrogenous compounds that include molecules that regulate lipid metabolism (Nie et al., 2018). Based on the current study results, growing rats fed a low protein diet as CSP was adequate to support growth and decreased adipogenesis compared to whey protein.

\subsection{Adipose Lipid Metabolism}

To determine molecular mechanisms that may have contributed to adiposity in whey-fed rats; we measured genes with potential to modulate adipose lipid content (hypertrophy) and differentiation (hyperplasia). Peroxisome proliferator-activated receptors (PPARs) belong to a ligand-activated nuclear hormone receptor superfamily and are known to regulate the expression of numerous genes involved in fatty acid metabolism and adipocyte differentiation (Schoonians et al., 1996). PPAR $\gamma$ is mainly expressed in adipose tissue where it has been shown to be an essential component in adipocyte differentiation (Braissant et al., 1996; Tontonoz et al., 1994). Our study found no differences in gene expression of PPAR $\gamma$ among diet groups suggesting greater gonadal adipose tissue weight in rats fed whey protein was not the results of increased adipose differentiation.

Lipid content of adipose tissue in rats provided the protein deficient diet were numerically lower than whey and CSP-fed rats. Regulation of DNL is mainly at the transcriptional level. Transcription factors SREBP-1c induces fatty acid synthesis and SREBP-2 is primarily responsible for cholesterol uptake (Song et al., 2018). The present study showed rats fed a deficient or low protein diet from different sources had no significant effect on SREBP-1c 
and SREBP-2 gene expression. This is because SREBP role in adipocyte DNL is minor. Instead, ChREBP is a major lipogenic transcription factor in adipocyte DNL (Song et al., 2018). In DNL, the key rate-limiting enzyme FAS converts malonyl-CoA into the first fatty acid product in DN, palmitic acid. In turn, palmitic acid (16:0) undergoes elongation to stearic acid (18:0) and desaturation by SCD-1 to palmitoleic acid (16:1) and oleic acid (18:1). Feeding 0\% protein or $10 \%$ casein, CSP, and whey protein diets had no significant effect on adipose ChREBP, FAS, SCD-1 gene expression or end products: palmitic, stearic, palmitoleic and oleic acid content. DNL is balanced by lipolysis and therefore, a reduction in adipocyte lipolysis may contribute to hypertrophy. In the current study, rats fed low casein, CSP, and whey protein diets had no significant effect on gene expression of HSL and PPAR $\alpha$ in gonadal adipose. Absence of significance may be because PPAR $\alpha$ has been reported to play a more important role in brown rather than white adipose tissue in rats (Barbera et al., 2001; Atgie et al., 1997). In our study there were also no difference among experimental diet groups in expression of genes regulating triglyceride synthesis, transport, and storage, DGAT2, MTTP, and LPL. Blais et al. (2017) evaluated changes induced by reducing dietary protein from standard $20 \%$ to low $6 \%$ kcal using either soy protein or casein. The low soy protein was lower in methionine (230 g) compared to casein (1.03 g) and showed increased energy expenditure (Blais et al., 2017). In our study, absence of differences in adipose DNL markers may be attributed to methionine content of the CSP, casein and whey protein diets of 17,27 , and $24 \mathrm{mg} / \mathrm{g}$ protein, respectively (Warren et al., 2020).

There was no significant difference in gene expression of NFKB transcription factor regulating COX-2 in the adipose tissue of rats fed CSP protein compared to whey protein or casein. However, a review conducted by Liddle et al. (2017) suggested eicosapentaenoic acid 
and docosahexaenoic consumption shifts the adipose tissue immune cell population toward a less inflammatory phenotype as suggested by the reduced macrophage ratio and increased antiinflammatory IL-10 production. In the present study, there were no significant differences in IL10 between rats fed $10 \%$ protein as either CSP, whey protein or casein. However, gene expression of IL-10 was upregulated $(\mathrm{p}<0.05)$ in rats fed casein compared to rats fed a protein deficient diet.

Collectively, results indicate low dietary protein provided from dairy or fish source had minimal effects on adipose lipid metabolism and inflammation in growing rats. However, Pezeshski et al. (2016) reported immature obesity-prone Sprague-Dawley rats fed protein restricted diets consisting of $10 \% \mathrm{kcal}$ egg protein resulted in greater liver fat content indicative of hepatic steatosis despite lack of increased total body fat. Therefore, the present study also investigated the effects of low protein diets from different sources on hepatic lipid metabolism in using immature Sprague-Dawley rats.

\subsection{Liver Metabolism}

NAFLD is defined as fat vacuoles in $>5 \%$ of hepatocytes evaluated by light microscopic examination of a hematoxylin and eosin stained liver section (4-5 $\mu \mathrm{m}$ thick) under a $10 \times$ objective lens (Sanyal et al., 2011). In the present study, all rats showed evidence of NAFLD. Rats fed the protein deficient diet showed the greatest accumulation of lipids in the liver as evident by the majority of rats having fat vacuoles in $>66 \%$ of hepatocytes and the greatest $(\mathrm{p}<$ 0.05) hepatic total lipid content. Hepatic fat infiltration was lower in rats fed low protein diets with fat vacuoles in $\leq 33 \%$ of hepatocytes. Further, hepatic fat infiltration differed depending on protein source. Rats fed casein and whey protein showed less evidence of liver steatosis compared to rats fed CSP. 
NAFLD has been characterized by liver steatosis and dysregulation of lipid metabolism (Lonardo et al., 2015). ChREBP, SREBP-1c and SREBP-2 are transcription factors involved in the regulation of DNL. Hepatic DNL is initiated with FAS producing the SFAs, palmitic (16:0) and stearic acids (18:0). Subsequently, SCD-1 can desaturate these fatty acids producing MUFAs, palmitoleic (16:1n-7) and oleic acids (18:1n-9). In our study, hepatic fatty acid composition showed rats fed the protein deficient diet had lower $(\mathrm{p}<0.05)$ stearic acid and greater oleic acids than protein-fed rats. However, rats fed the protein deficient diets did not exhibit differences in expression of DNL gene markers compared to the protein-fed groups. Additionally, DNL transcription factors and enzymes gene expression did not differ among the protein-fed rats regardless of source. Subsequently, there were also no differences in liver DNL end products: palmitic, stearic, palmitoleic, or oleic acids among rats fed protein diets.

In the absence of DNL alterations, reduced lipolysis may explain the greater liver steatosis. In lipolysis, HSL catalyzes the conversion of diacylglycerols to monoacylglycerols (Lee et al., 2015). In the liver, transcription factors, PPAR $\alpha$ and PPAR $\gamma$, regulate of lipolysis and lipid oxidation. Upregulation of PPAR $\alpha$ and PPAR $\gamma$ enhance the use of lipids for metabolism and have been targets for NAFLD therapeutics (Kersten et al., 2000; Fuchs et al., 2014). In the current study, there were no differences in expression in HSL PPAR $\alpha$ and PPAR $\gamma$ among the experimental diet groups.

Other key characteristics of NAFLD were dysregulation of triglyceride synthesis, transport, and storage (Romeo et al., 2008). DGAT2 is the rate limiting step in the biosynthesis of hepatic triglyceride production and increase DGAT2 activity contribute to liver steatosis (Wang et al., 2010). To prevent excessive liver storage, triglycerides are packaged into VLDL for transport to extrahepatic tissue by MTTP. In our study, hepatic gene expression of DGAT2 
and MTTP did not differ among diet groups. However, hepatic LPL expression was increased in the casein-fed rats compared to rats fed a protein deficient diet.

LPL is the rate limiting enzyme in the hydrolysis of triglycerides in chylomicrons and VLDL that allows uptake of fatty acid acids by tissues (Goldberg, 1996). LPL is typically only found in extrahepatic tissues with greater concentrations found in adipose and muscle tissues (Semenkovich et al., 1989). In a human clinical study, Pardina et al. (2009) report in expression of hepatic LPL mRNA is significantly elevated in subjects with NAFLD compared to subjects with no liver disease. LPL overexpression in mouse liver causes liver-specific insulin resistance and exacerbates triglyceride accumulation in the liver (Kim et al., 2001). Therefore, our data suggests that rats consuming casein-based low protein diets may be at greater risk for the development of fatty liver. Furthermore, Hardardottir et al. (1994) reported that cytokines can induce liver LPL expression in adults.

Inflammation and reactive oxygen species from fatty acid metabolism promotes NAFLD progression to non-alcoholic steatohepatitis (NASH) (Michelotti et al., 2013). The transcription factor $\mathrm{NF \kappa B}$, is a key regulator in $\mathrm{COX}-2$ expression and subsequent pro-inflammatory responses (Lee at al., 2015; Lim et al., 2001). COX-2 catalyzes the conversion of arachidonic acid to pro-inflammatory prostaglandins. In our study, there were no differences in NFKB or COX-2 hepatic expression among experimental diet groups. Additionally, there were no differences in liver damage serum biomarkers ALT and AST among protein-fed rats. Additionally, NASH has been associated with lipoprotein dysregulation (Suzuki et al., 2017). However, in the present study, there were no differences in serum triglyceride, VLDL, and LDL levels among experimental diet groups. Absence of inflammation, hepatic damage, and lipid dysregulation in experimental diet groups indicated NAFLD did not progress to the more severe 
NASH. Further suggesting low inflammatory status among the experimental groups, there were no differences in IL-10 expression. IL-10 has been suggested to be one of the most important anti-inflammatory cytokines (Stenvinkel et al., 2005).

\section{Conclusion}

Based on the results, CSP showed merit for commercial use in low protein formulas. Unlike whey protein, CSP consumption did not elevate body weight or adiposity. Instead, CSP demonstrated properties comparable to casein. Additionally, consumption of low CSP did not alter expression of genes regulating lipid metabolism as was observed in rats fed casein that contribute to NAFLD development or inflammation that promotes progression to NASH. Based on our animal study, CSP is not only a physiologically safe option, but may be preferable to whey protein for preventing increased adiposity. Branch chain amino acids in whey protein isolate may have stimulated insulin and IGF-1 resulting in adipogenesis. However, more studies are needed. Based on study results, sarcoplasm protein recovered from wash water from processing of carp, an invasive species could be marketed as a sustainable novel protein alternative to current commercial protein powder 


\section{References:}

1. Atgie, C., D’Allaire, F., Bukowiecki, L., J. (1997). Role of $\beta 1$ - and $\beta 3$-adrenoceptors in the regulation of lipolysis and thermogenesis in rat brown adipocytes. American Journal of Physiology, 273, C1136-C1142,

2. Barbera, M., J., Schluter, A., Pedraza, N., Iglesias, R., Villarroya, F., Giralt, M. (2001). Peroxisome proliferator-activated receptor activates transcription of the brown fat uncoupling protein-1 gene: a link between regulation of the thermogenic and lipid oxidation pathways in the brown fat cell. Journal of Biological Chemistry, 276, 1486 1493.

3. Blais, A., Chaumontet, C., Azzout-Marniche, D., Piedcoq, J., Fromentin, G., Gaudichon, C., Tomé, D., Even, P., C, (2018). Low-protein diet-induced hyperphagia and adiposity are modulated through interactions involving thermoregulation, motor activity, and protein quality in mice. American Journal of Physiology: Endocrinology and Metabolism, 314(2), E139-E151. doi: 10.1152/ajpendo.00318.2017

4. Bligh E, Dyer W. (1959) A rapid method of total lipid extraction and purification. Can J Journal of Biochemistry and Physiology, 37, 911-917. doi: 10.1139/y59-099

5. Boirie, Y., M., Dangin, P., Gachon, M., P., Vasson, J., L., Maubois, Beaufrere. B. (1997). Slow and fast dietary proteins differently modulate postprandial protein accretion. Proceedings of the National Academy of Sciences of the USA. 94, 14930-14935.

6. Bossola M. (2015) Nutritional interventions in head and neck cancer patients undergoing chemoradiotherapy: a narrative review. Nutrients, 7, 265-76. 
7. Braissant, O., Foufelle, F., Scotto, C., Dauca, M., Wahli, W. (1996). Differential expression of peroxisome proliferator activated receptors (PPARs): tissue distribution of PPAR -alpha, -beta, and -gamma in the adult rat. Endocrinology, 137(1), 354-366.

8. Brunt, E., Janney, C., Bisceglie, A., Neuschwander-Tetri, B., Bacon, B. (1999).

Nonalcoholic steatohepatitis: A proposal for grading and staging the histological lesions. American Journal of. Gastroenterology. 94, 2467-2474.

9. Caballero V., Mendieta J., Lombardo D., Saceda M., Ferragut J., Conde R., et al. (2015). Liver damage and caspase-dependent apoptosis is related to protein malnutrition in mice: effect of methionine. Acta Histochemica, 2015, 117, 126-35.

10. Chick J. (2001) Invasive Carp in the Mississippi River Basin. Science, 292, 2250-2251. doi: $10.1126 /$ science.292.5525.2250

11. Deo MG. (1978). Biology of protein-calorie malnutrition. World Review of Nutrition and Dietetics, 3249-95.

12. Demonty, I., Deshaies, Y., Lamarche, B., Jacques, H. (2003) Cod protein lowers the hepatic triglyceride secretion rate in rats. Nutrient Interactions and Toxicity 133(5), 13981402, https://doi.org/10.1093/jn/133.5.1398

13. FAO, Food and Agriculture Organization of the United Nations. (2016). The State of World Fisheries and Aquaculture, 2016. Rome, Italy: Author. Retrieved from https://www.fao.org/3/a-i5555e.pdf.

14. Feres N., Reis S., Veloso R., Arantes V., Souza L., Carneiro E., et al. (2010). Soybean diet alters the insulin-signaling pathway in the liver of rats recovering from early-life malnutrition. Nutrition, 26, 441-8. 
15. Fock R., Rogero M., Vinolo M., Curi R., Borges M., Borelli P. (2010). Effects of proteinenergy malnutrition on NF-kappaB signalling in murine peritoneal macrophages. Inflammation, 33, 101-9.

16. Fritsche K., Johnston P. (1990) Effect of dietary alpha-linolenic acid on growth, metastasis, fatty acid profile and prostaglandin production of two murine mammary adenocarcinomas. Journal of Nutrition. 189, 52-60. doi: 10.1093/jn/120.12.1601

17. Fuchs, C., Claudel, T., Trauner, M. (2014). Role of metabolic lipases and lipolytic metabolites in the pathogenesis of NAFLD. Trends in Endocrinology and Metabolism. 25, $576-585$.

18. Gil, A., Ramirez, M., Gil, M. (2003). Role of long-chain polyunsaturated fatty acids in infant nutrition. European Journal of Clinical Nutrition. 57(1), S31-4.

19. Goldberg, I.. (1996). Lipoprotein lipase and lipolysis: central roles in lipoprotein metabolism and atherogenesis. Journal of Lipid Research. 37, 693-707.

20. Gomes S., da Silva A., Crisma A., Borelli P., Hernandez-Blazquez F., de Melo M., Bacci B., Loesch A., Coppi A.. (2017). Stereology shows that damaged liver recovers after protein refeeding. Nutrition. 38, 61-69. doi: 10.1016/j.nut.2017.02.010.

21. Hardardottir, Grunfeld, I., and Feingold. K. (1994). Effects of endotoxin and cytokines on lipid metabolism. Current Opinion in Lipidology. 5, 207-215

22. Jacometo C., Schmitt E., Pfeifer L., Schneider A., Bado F., da Rosa F., Halfen S., Del Pino F., Loor J., Corrêa M., Dionello N. (2014). Linoleic and $\alpha$-linolenic fatty acid consumption over three generations exert cumulative regulation of hepatic expression of genes related to lipid metabolism. Genes and Nutrition, 9, 405-416. doi: 10.1007/s12263-014-0405-7 
23. Kersten, S., Desvergne, B., Wahli, W. (2000). Roles of PPARs in health and disease. Nature. 405, 421-424.

24. Kim, J., K., Fillmore, J., J., Chen, Y., Yu, C., Moore, I., K., Pypaert, M., (2001). Tissuespecific overexpression of lipoprotein lipase causes tissue-specific insulin resistance. Proceedings of the National Academy of Science. 98, 7522-7527.

25. Koletzko, B., von Kries, R., Closa, R., Escribano, J., Scaglioni, S., Giovannini, M., Beyer, J., Demmelmair, H., Gruszfeld, D., Dobrzanska, A., Sengier, A., Langhendries, J., P., Rolland Cachera M., F., Grote, V. (2009). Lower Protein in Infant Formula is Associated with Lower Weight up to age 2 y: a Randomized Clinical Trial. American Journal of Clinical Nutrition, 89, 1836-1845. http://doi.org/10.3945/ajen.2008.27091.

26. Kumar V, Deo MG, Ramalingaswami V. (1972) Mechanism of Fatty Liver, in Protein Deficiency. Gastroenterology, 62, 3, 445-451. doi: 10.1016/S0016-5085(72)80153-7

27. Lee, J., Lambert, J., Hovhannisyan, Y., Ramos-Roman, M., Trombold, J., Wagner, D., Parks, E., (2015) Palmitoleic acid is elevated in fatty liver disease and reflects hepatic lipogenesis. American Journal of Clinical Nutrition. 101, 34-43.

28. Lee, Y., Yang, Y., Huang, P., Li, W., Huang, M., Kao, C., Chenag, Y., Chen. M. (2015). Exercise suppresses COX-2 pro-inflammatory pathway in vestibular migraine. Brain Research Bulletin. 116, 98-105. https://doi.org/10.1016/j.brainresbull.2015.06.005

29. Liaset, B., Madsena, L., Hao, Q., Criales, G., Mellgren, G., Marschall, H., Hallenborg, P., Espe, M., Frøyl, L., and Kristiansen. K. (2009). Fish protein hydrolysate elevates plasma bile acids and reduces visceral adipose tissue mass in rats. Biochimica et Biophysica Acta. 1791(4), 254-262. https://doi.org/10.1016/j.bbalip.2009.01.016 
30. Liddle, D., M., Hutchinson, A., L., Wellings, H., R., Power, K., A., Robinson, L., E., Monk, J., M. (2017). Integrated Immunomodulatory Mechanisms through which LongChain n-3 Polyunsaturated Fatty Acids Attenuate Obese Adipose Tissue Dysfunction. Nutrients, 9(12). pii: E1289. doi: 10.3390/nu9121289.

31. Lim J., Kim H., Kim K. (2001). Nuclear factor-kappaB regulates cyclooxygenase-2 expression and cell proliferation in human gastric cancer cells. Laboratory Investigation. 81(3), 349-60.

32. Ljubojević D, Đorđević V, Ćirković M. (2017) Evaluation of nutritive quality of common carp, Cyprinus carpio L. IOP Conference Series: Earth and Environmental Science, 85, 012-013. doi: 10.1088/1755-1315/85/1/012013

33. Lonardo, A., Ballestri, S., Marchesini, G., Angulo, P., Loria, P.(2015). Nonalcoholic fatty liver disease: A precursor of the metabolic syndrome. Digestive and Liver Disease. 47, $181-190$.

34. Melnik, B.C. (2012). Excessive Leucine-mTORC1-signalling of Cow Milk-based Infant Formula: The Missing Link to Understand Early Childhood Obesity. Journal of Obesity, 2012, 197653. http://doi.org/10.1155/2012/197653.

35. Michelotti, G., A., Machado, M., V., Diehl, A., M. (2013). NAFLD, NASH and liver cancer. Nature Reviews Gastroenterology and Hepatology, 10(11), 656-665. doi:10.1038/nrgastro.2013.183

36. National Research Council. (2011) Guide for the care and use of laboratory animals. The National Academies Press, 8, 11-65. doi: 10.17226/12910 
37. Nie, C., He, T., Zhang, W., Zhang, G., Ma, X. (2018). Branch Chain Amino Acids: Beyond Nutrition Metabolism, International Journal of Molecular Science, 19(4). pii: E954. http://doi.org/10.3390/ijms19040954.

38. Narayan, B., Yamaguchi, K., Hosokawa, M., Fukunaga, K., Nishiyama, T. (2009). Effect of marine protein supplementation of lipid profile of growing rats compared to soybean and casein. Food Science and Biotechnology., 18(6), 1330-1335

39. O’Connell TM. (2013). The Complex Role of Branched Chain Amino Acids in Diabetes and Cancer. Metabolites, 3, 931-945; doi:10.3390/metabo3040931

40. Ong K., Loos R. (2006). Rapid infancy weight gain and subsequent obesity: systematic reviews and hopeful suggestions. Acta Paediatrica. 95(8), 904-8.

41. Ong, K., Langkamp, M., Ranke, M., Whitehead, K., Hughes, I., Acerini, C., Dunger. D. (2009). Insulin-like growth factor I concentrations in infancy predict differential gains in body length and adiposity: the Cambridge Baby Growth Study. The American Journal of Clinical Nutrition, 90(1), 156-161, doi 10.3945/ajen.2008.27408

42. Pardina, E., Baena-Fustegueras, J., A., Llamas, R., Catalan, R., Galard, R., Lecube, A. (2009). Lipoprotein lipase expression in livers of morbidly obese patients could be responsible for liver steatosis. Obesity Surgery. 19, 608-616.

43. Pezeshki, A., Zapata, R., Singh, A., Yee, N., Chelikani, P. (2016). Low protein diets produce divergent effects on energy balance. Science Reports. 6, 25145; doi: $10.1038 /$ srep25145.

44. Romeo, S.; Kozlitina, J.; Xing, C.; Pertsemlidis, A.; Cox, D.; Pennacchio, L.A.; Boerwinkle, E., Cohen, J., Hobbs, H. (2008). Genetic variation in PNPLA3 confers susceptibility to nonalcoholic fatty liver disease. Nature Genetics. 40, 1461-1465. 
45. Sanyal. A., J., Brunt, E., M., Kleiner, D., E., Kowdley. K., V., Chalasani, N., Lavine, J., E,, Ratziu., V., McCullough, A. (2011). Endpoints and clinical trial design for nonalcoholic steatohepatitis. Hepatology, 54, 344-353

46. Sauerwein, R., Mulder, J., Mulder, L., Lowe, B., Peshu, N., Demacker, P., van der Meer, J., Marsh K. (1997). Inflammatory mediators in children with protein-energy malnutrition. Am Journal of Clinical Nutrition. 65(5), 1534-9.

47. Schoonjans, K., Staels, B., Auwerx, J., (1996). The peroxisome proliferator activated receptors (PPARs) and their effects on lipid metabolism and adipocyte differentiation. Biochimica et Biophyisica Acta. 1302, 93-109

48. Semenkovich, C., Chen, S., Wims, M., Luo, C., Li, W., and Chan. L. (1989). Lipoprotein lipase and hepatic lipase mRNA tissue specific expression, developmental regulation, and evolution. Journal of Lipid Research. 30, 423-431

49. Spector A. (1984). Plasma lipid transport. Clinical Physiology and Biochemistry. 2(2-3), 123-34.

50. Stenvinkel P., Ketteler M., Johnson R., Lindholm B., Pecoits-Filho R., Riella M., Heimbürger O., Cederholm T., Girndt M. (2005). IL-10, IL-6, and TNF- $\alpha$ : Central factors in the altered cytokine network of uremia-The good, the bad, and the ugly. Kidney International. 67(4), 1216-1233. https://doi.org/10.1111/j.1523-1755.2005.00200.x

51. Suzuki, A., Diehl, A., M. (2017). Nonalcoholic Steatohepatitis. Annual Review of Medicine. 2017, 68(1), 85-98. doi:10.1146/annurev-med-051215-031109

52. Tang M. (2018). Protein Intake during the First Two Years of Life and Its Association with Growth and Risk of Overweight. International Journal of Environmental Research \& Public Health. 15(8), E1742. http://doi.org/10.3390/ijerph15081742. 
53. Timby, N., Domellöf, E., Hernell, O., Lönnerdal, B., Domellöf, M. (2014).

Neurodevelopment, nutrition, and growth until 12 mo of age in infants fed a low-energy, low-protein formula supplemented with bovine milk fat globule membranes: a randomized controlled trial. American Journal of Clinical Nutrition, 99(4), 860-868.

54. Tontonoz, P., Hu, E., Spiegelman, B., M. (1994). Stimulation of adipogenesis in fibroblasts by PPAR-2, a lipid-activated transcription factor. Cell, 79, 1147-1156

55. Wang, Z., Yao, T., Song, Z. (2010). Involvement and mechanism of DGAT2 upregulation in the pathogenesis of alcoholic fatty liver disease. Journal of Lipid Research, 51, 31583165 .

56. Warren, D., Soule, L., Taylor, K., Skinner R., C., Ku, K., M., Matak, K., Benedito, V., A., Tou, J., C. (2020). Protein Quality and Safety Evaluation of Sarcoplasmic Protein-Derived from Silver Carp (Hypophthalmichthys molitrix) Using a Rat Model. Journal of Food Science. (accepted).

57. Warren D, Paker I, Jaczynski J, \& Matak KE. (2018). Nutritional Quality and Physical Characteristics of Soluble Proteins Recovered from Silver Carp. Journal of Food Science, 83(7), 1970-1979. http://doi.org/10.1111/1750-3841.14170

58. Xin Y, Xuan S, Zhang J, Zheng M, Guan H. (2008) Omega-3 polyunsaturated fatty acids: A specific liver drug for non-alcoholic fatty liver disease (NAFLD). Medical Hypotheses, 71, 820-821. doi: 10.1016/j.mehy.2008.07.008

59. Zutphen, T., Ciapaite, J., Bloks, V., Ackereley, C., Gerding, A., Jurdzinski, A., et al. (2016). Malnutrition-Associated Liver Steatosis and ATP Depletion is caused by Peroxisomal and Mitochondrial Dysfunction. Journal of Hepatology, 65(6), 1198-1208. http://doi.org/10.1016/j.jhep.2016.05.046. 


\section{Figure and Tables}

Table 1: List of primers used for RT-qPCR analysis.

\begin{tabular}{|c|c|c|c|}
\hline Gene & NCBI Accession Number & Forward Primer & Reverse Primer \\
\hline ChREBP & NM_133552.1 & 5' CCTTAATGGGATGGTGTCT 3' & 5' AGAGCAGGGCAGGGAACAGTA 3' \\
\hline SREBP-1c & NM_001276707.1 & 5' GCCTGCTTGGCTCTTCTCT 3' & 5' GCTTGTTTGCGATGTCTCC 3' \\
\hline SREBP-2 & NM_001033694.1 & 5' TGATGCCGACTCTACTGCTG 3' & 5' CACGAAGACGCTCAAGACAA 3' \\
\hline FAS & NM_017332.1 & 5' GCTGCTACAAACAGCACCATC 3' & 5' TCCACTGACTCTTCACAGACCA 3' \\
\hline SCD-1 & NM_139192.2 & 5' TTCGCCACTGACTTGCTATG 3' & 5' CAGGAGGTTCTTGGGATGATT 3' \\
\hline PPAR $\alpha$ & NM_013196.1 & 5' ATGAACAAAGACGGGATGCT 3' & 5' AGGAACTCTCGGGTGATGAA 3' \\
\hline PPAR $\gamma$ & NM_013124.3 & 5' GCAAAGACAACAGACAAATCACC 3' & 5' CGAAACTGGCACCCTTGA 3' \\
\hline HSL & NM_012859.1 & 5' TCTCCAAGTGTGTAGCGCCTA 3' & 5' AACTCCAGGAAGGAGTTGAGC 3' \\
\hline MTTP & NM_001107727.1 & 5' TCAGGTGCTGTGTATTCTGCT 3' & 5' CGTGTTCCACTTCCGTTCT 3' \\
\hline DGAT2 & NM_001012345.1 & 5' CACCCTCCTGTGTATTCTGCT 3' & 5' TTTGGCTGTTCTTGTTTCCA 3' \\
\hline LPL & NM_012598.2 & 5' CGCTCCATCCATCTCTTCAT 3' & 5' TTTCTCAAATGCCTCCTTGG 3' \\
\hline $\mathrm{NF} \kappa \mathrm{B}$ & NM_001145138.2 & 5' TTATGGGCAGGATGGACCTA 3' & 5' CCTTTCAGGGCTTTGGTTTA 3' \\
\hline $\mathrm{COX}-2$ & NM_017232.3 & 5' CGGAGGAGAAGTGGGTTTTAG 3' & 5' TGAAAGAGGCAAAGGGACAC 3' \\
\hline IL-10 & NM_012854.2 & 5' CACTGCTATGTTGCCTGCTC 3' & 5' GCCTTTGCTGGTCTTCACTC 3' \\
\hline$\beta$-actin & NM_031144.2 & 5' TTGCTGACAGGATGCACAAG 3' & 5' CAGTGAGGCCAGGATAGAGC 3' \\
\hline GAPDH & NM_017008.4 & 5' TCAAGAAGGTGGTGAAGCAG 3' & 5' CCTCAGTGTAGCCCAGGATG 3' \\
\hline
\end{tabular}

Abbreviations: ChREBP, carbohydrate-response element-binding protein; SREBP-1c, Sterol regulatory element-binding protein-1c; SREBP-2, Sterol regulatory element-binding protein-2; FAS, fatty acid synthase; SCD-1, Stearoyl-CoA desaturase-1; PPAR $\alpha$,

Peroxisome proliferator-activated receptor alpha; PPAR $\gamma$, peroxisome proliferator-activated receptor gamma; HSL, hormone sensitive lipase; DGAT2, diacylglycerol O-acyltransferase 2; LPL, lipoprotein lipase; MTTP, microsomal triglyceride transfer protein; COX-2, cyclooxygenase 2; IL-10, interleukin 10; NFkB, nuclear factor kappa-light-chain-enhancer of activated B cells; GAPDH,

glyceraldehyde 3-phosphate dehydrogenase. 
Table 2: Composition of rodent diets substituted with $10 \%$ kcal protein of carp sarcoplasmic protein, casein or whey protein isolate.

\begin{tabular}{ccccc}
\hline & \multicolumn{4}{c}{ Treatments $^{\mathbf{1}}$} \\
\cline { 2 - 5 } CSP & Casein & Whey & No-Protein \\
\hline Ingredient (g/kg) & & & 111 & - \\
Whey Protein Isolate & - & - & - & - \\
Casein & - & 115 & - & - \\
Carp Protein & 131.5 & - & 495.286 & 605.986 \\
Corn Starch & 482.236 & 492.036 & 495 & 132 \\
Maltodextrin & 132 & 132 & 132 & 100 \\
Sucrose & 100 & 100 & 100 & 70 \\
Soybean Oil & 66.5 & 70 & 70 & 50 \\
Cellulose & 50 & 50 & 50 & 13.4 \\
Mineral Mix & 13.4 & 13.4 & 13.4 & 13.4 \\
Calcium Phosphate & 0.75 & 9.8 & 13.2 & 2.7 \\
Calcium Carbonate & 11.1 & 5.25 & 2.6 & 10 \\
Vitamin Mix & 10 & 10 & 10 & 2.5 \\
Choline Bitartate & 2.5 & 2.5 & 2.5 & 0.014 \\
TBHQ, antioxidant & 0.014 & 0.014 & 0.014 & 0 \\
\hline Macronutrients (\% kcal) & & & & 7 \\
Protein & 10 & 10 & 10.3 & 3.8 \\
Carbohydrate & 66.9 & 67.8 & 68.1 & 78.1 \\
Fat & 7 & 7.1 & 7 & 7.8 \\
\hline Calories (kcal/g) & 3.7 & 3.8 & 3.8 & 3.8
\end{tabular}

Abbreviations: CSP, carp sarcoplasmic protein; TBHQ, tert-butylhydroquinone 
Table 3: Fatty acid analysis of rodent diets substituted with $10 \%$ kcal protein of carp sarcoplasmic protein, casein or whey protein.

\begin{tabular}{|c|c|c|c|c|}
\hline \multirow[b]{2}{*}{ Measurements (\%) } & \multicolumn{4}{|c|}{ Treatments $^{1}$} \\
\hline & CSP & Casein & Whey & No-Protein \\
\hline \multicolumn{5}{|l|}{ SFAs } \\
\hline Palmitic acid 16:0 & $10.94 \pm 0.73$ & $10.61 \pm 0.10$ & $11.07 \pm 0.16$ & $10.98 \pm 0.15$ \\
\hline Stearic acid 18:0 & $4.09 \pm 0.27$ & $3.87 \pm 0.14$ & $4.13 \pm 0.05$ & $3.92 \pm 0.20$ \\
\hline \multicolumn{5}{|l|}{ MUFAs } \\
\hline Palmitoleic acid 16:1 & $0.18 \pm 0.09^{\mathrm{a}}$ & $0.00 \pm 0.00^{\mathrm{b}}$ & $0.00 \pm 0.00^{\mathrm{b}}$ & $0.00 \pm 0.00^{b}$ \\
\hline Oleic acid $18: \ln 9 \mathrm{c}$ & $18.10 \pm 0.95$ & $20.11 \pm 1.96$ & $18.95 \pm 0.51$ & $19.65 \pm 0.25$ \\
\hline \multicolumn{5}{|c|}{ / } \\
\hline Linoleic acid 18:2n6c & $41.13 \pm 2.12$ & $48.79 \pm 2.60$ & $43.89 \pm 0.51$ & $47.43 \pm 2.20$ \\
\hline$\alpha$-linoleic acid C18:3n3 & $5.72 \pm 0.24$ & $7.03 \pm 0.54$ & $6.12 \pm 0.17$ & $6.77 \pm 0.46$ \\
\hline Arachidonic acid C20:4 & $0.00 \pm 0.00$ & $0.00 \pm 0.00$ & $0.00 \pm 0.00$ & $0.00 \pm 0.00$ \\
\hline Eicosapentaenoic acid C20:5n3 & $0.00 \pm 0.00$ & $0.00 \pm 0.00$ & $0.00 \pm 0.00$ & $0.00 \pm 0.00$ \\
\hline Docosahexaenoic acid 22:6n3 & $0.00 \pm 0.00$ & $0.00 \pm 0.00$ & $0.00 \pm 0.00$ & $0.00 \pm 0.00$ \\
\hline
\end{tabular}




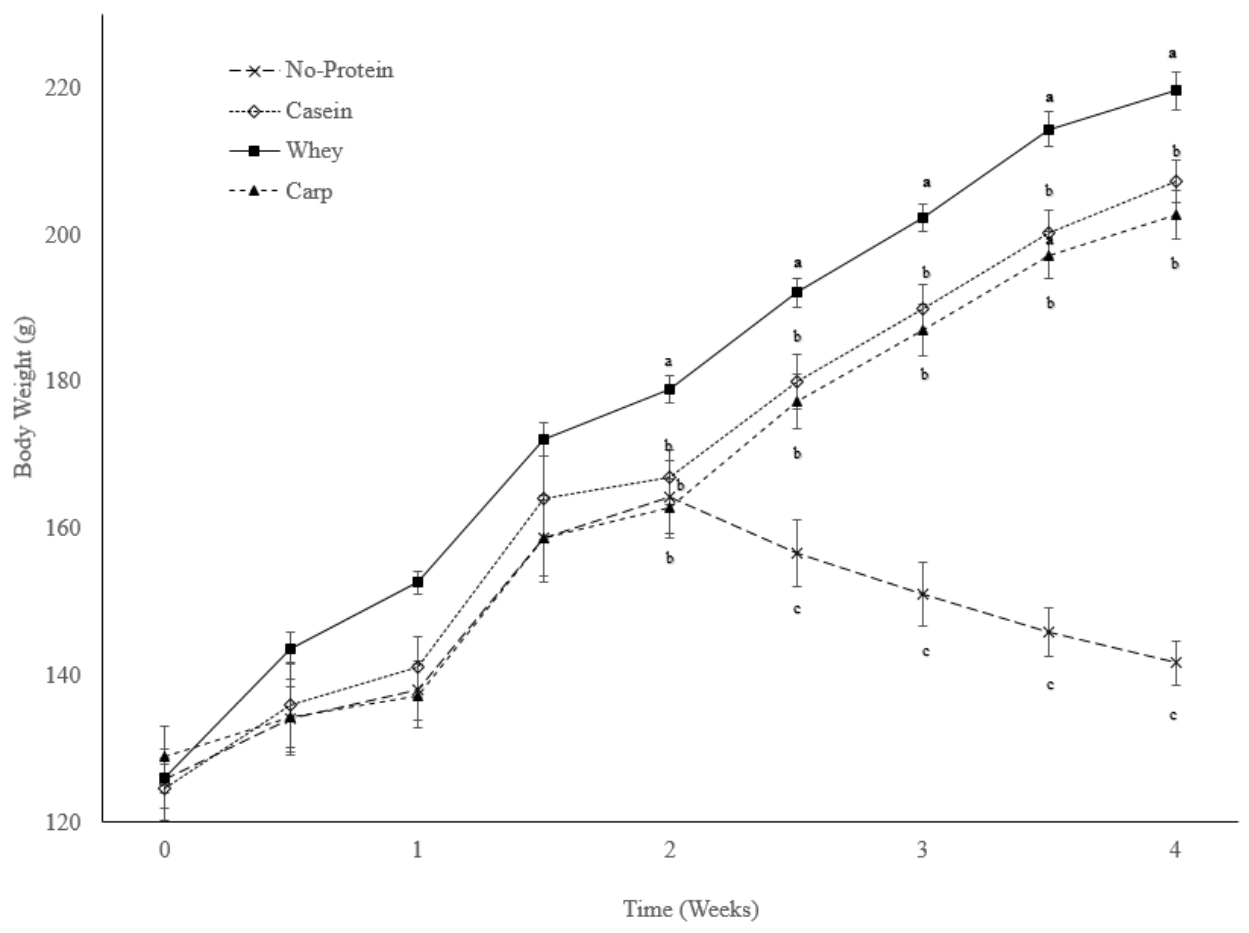

Figure 1: Body weights of female rats fed $10 \%$ protein diets consisting of carp sarcoplasmic protein (Carp), casein, whey protein isolate, or 2 weeks on $10 \%$ casein diet followed by a noprotein diet. Values are mean \pm SEM of $n=8$ rats/group. Letters $(a, b, c)$ shows significant difference at $\mathrm{p}<0.05$ determined by ANOVA followed by Tukey's HSD. 
Table 4: Effect of the consumption of different diets substituted with $10 \%$ kcal protein consisting of carp sarcoplasmic protein, casein or whey protein for four weeks on growth parameters of growing female rats.

\begin{tabular}{lcccc} 
& \multicolumn{3}{c}{ Treatment $^{1}$} \\
\cline { 2 - 5 } Growth Parameters & CSP & Casein & Whey & No-Protein \\
\hline Total diet intake (g) & $449.98 \pm 3.13^{\mathrm{a}}$ & $441.65 \pm 6.99^{\mathrm{a}}$ & $460.49 \pm 1.79^{\mathrm{a}}$ & $380.59 \pm 11.52^{\mathrm{b}}$ \\
Caloric intake (kcal) & $1664.91 \pm 43.78^{\mathrm{a}}$ & $1678.26 \pm 26.57^{\mathrm{a}}$ & $1749.87 \pm 43.77^{\mathrm{a}}$ & $1446.24 \pm 43.78^{\mathrm{b}}$ \\
Feed efficiency (g body wt/g diet intake) & $0.16 \pm 0.004^{\mathrm{b}}$ & $0.19 \pm 0.009^{\mathrm{ab}}$ & $0.20 \pm 0.006^{\mathrm{a}}$ & $0.04 \pm 0.007^{\mathrm{c}}$ \\
Final body weight (g) & $202.85 \pm 3.33^{\mathrm{b}}$ & $207.26 \pm 2.89^{\mathrm{b}}$ & $219.66 \pm 2.66^{\mathrm{a}}$ & $141.70 \pm 2.98^{\mathrm{c}}$ \\
Total body weight gain (g) & $73.93 \pm 1.71^{\mathrm{b}}$ & $82.68 \pm 4.04^{\mathrm{ab}}$ & $93.69 \pm 3.11^{\mathrm{a}}$ & $15.82 \pm 2.75^{\mathrm{c}}$ \\
Liver weight (g) & $8.45 \pm 0.47^{\mathrm{a}}$ & $8.48 \pm 0.35^{\mathrm{a}}$ & $9.54 \pm 0.52^{\mathrm{a}}$ & $5.4 \pm 0.19^{\mathrm{b}}$ \\
Relative liver weight (g / g bwt.) & $4.15 \pm 0.18$ & $4.10 \pm 0.14$ & $4.18 \pm 0.17$ & $3.89 \pm 0.15$ \\
Gonadal fat pad weight (g) & $2.62 \pm 0.46^{\mathrm{b}}$ & $3.26 \pm 0.53^{\mathrm{ab}}$ & $5.10 \pm 0.68^{\mathrm{a}}$ & $1.47 \pm 0.35^{\mathrm{b}}$ \\
Relative gonadal fat pad (g /g bwt) & $1.28 \pm 0.22^{\mathrm{b}}$ & $1.57 \pm 0.25^{\mathrm{ab}}$ & $2.31 \pm 0.31^{\mathrm{a}}$ & $1.06 \pm 0.25^{\mathrm{b}}$ \\
\hline
\end{tabular}

${ }^{1}$ Values expressed as mean \pm SEM ( $n=6-8$ rats/group). Different superscript letters $a, b$, and c within the same row indicate significant difference at $\mathrm{p}<0.05$ by one-way ANOVA followed by Tukey's HSD. Abbreviations: CSP, carp sarcoplasmic protein. 


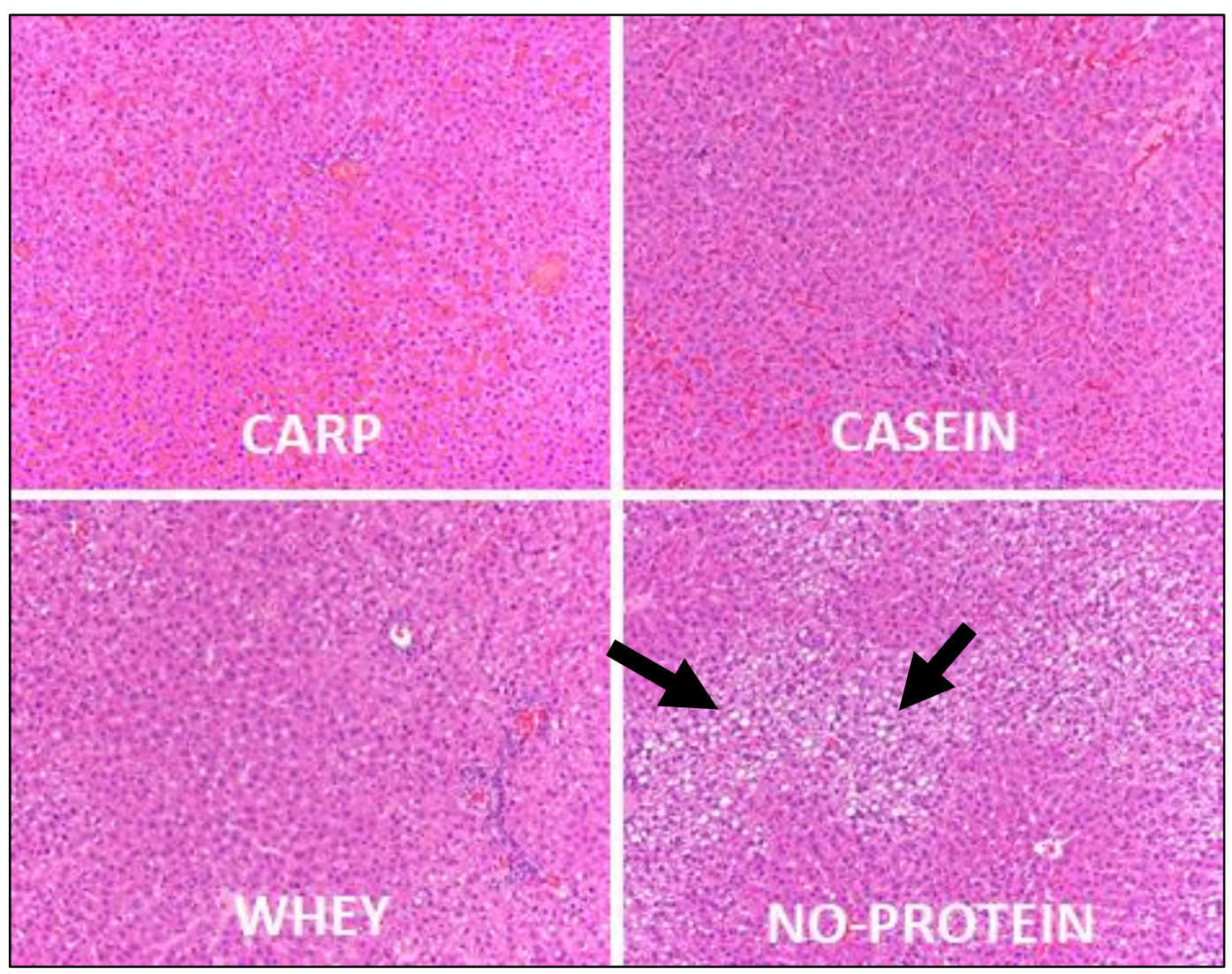

\begin{tabular}{ccccc}
\hline Measurement & CSP & Casein & Whey & No-protein \\
\hline \multicolumn{2}{c}{ Steatosis Grade } & & & \\
\hline 0 & - & 2 & 2 & - \\
1 & 3 & 1 & 1 & - \\
2 & - & - & - & 1 \\
3 & - & - & - & 2 \\
\hline
\end{tabular}

Figure 2: Representative histological staining images of the liver of growing female rats fed different proteins or no-protein diets. Arrows indicate locations of fat deposition. Scores analyzed by chi-square test at $p<0.05$. 
Table 5: Effect of the consumption of different diets substituted with $10 \%$ kcal protein of carp sarcoplasmic protein, casein or whey protein for four weeks on hepatic fatty acid composition and total lipid content.

\begin{tabular}{lcccc}
\hline & \multicolumn{4}{c}{ Treatments $^{\mathbf{1}}$} \\
\cline { 2 - 5 } Measurements & CSP & Casein & Whey & No-Protein \\
\hline SFAs (relative \%) & $19.12 \pm 1.57$ & $19.53 \pm 0.50$ & $18.17 \pm 1.58$ & $19.66 \pm 0.94$ \\
Palmitic acid 16:0 & $19.88 \pm$ & & & \\
& $1.29^{\mathrm{a}}$ & $15.28 \pm 1.71^{\mathrm{a}}$ & $18.45 \pm 0.79^{\mathrm{a}}$ & $6.77 \pm 0.43^{\mathrm{b}}$ \\
Stearic acid 18:0 & & & & \\
MUFAs (relative \%) & $1.03 \pm 0.40$ & $0.99 \pm 0.27$ & $0.95 \pm 0.15$ & $1.19 \pm 0.08$ \\
Palmitoleic acid 16:1 & $10.18 \pm$ & & & $20.81 \pm$ \\
Oleic acid 18:1n9c & $1.99^{\mathrm{b}}$ & $10.64 \pm 1.96^{\mathrm{b}}$ & $11.70 \pm 0.94^{\mathrm{b}}$ & $1.29^{\mathrm{a}}$ \\
PUFAs (relative \%) & & & & \\
& $11.74 \pm$ & & & $23.21 \pm$ \\
Linoleic acid 18:2n6c & $1.31^{\mathrm{b}}$ & $11.26 \pm 2.07^{\mathrm{b}}$ & $10.34 \pm 0.62^{\mathrm{b}}$ & $1.67^{\mathrm{a}}$ \\
$\alpha$-linoleic acid C18:3n3 & $0.56 \pm 0.06^{\mathrm{b}}$ & $0.64 \pm 0.10^{\mathrm{b}}$ & $0.49 \pm 0.04^{\mathrm{b}}$ & $1.56 \pm 0.09^{\mathrm{a}}$ \\
Arachidonic acid C20:4n6 & $0.00 \pm 0.00$ & $0.00 \pm 0.00$ & $0.00 \pm 0.00$ & $0.14 \pm 0.03$ \\
Eicosapentaenoic acid C20:5n3 & $0.00 \pm 0.00$ & $0.00 \pm 0.00$ & $0.00 \pm 0.00$ & $0.00 \pm 0.00$ \\
Docosahexaenoic acid 22:6n3 & $0.00 \pm 0.00$ & $0.00 \pm 0.00$ & $0.00 \pm 0.00$ & $0.00 \pm 0.00$ \\
\hline & & & & $19.96 \pm$ \\
Total Lipid Content (\%) & $6.91 \pm 0.99^{\mathrm{b}}$ & $8.73 \pm 1.85^{\mathrm{b}}$ & $4.62 \pm 0.99^{\mathrm{b}}$ & $4.13^{\mathrm{a}}$ \\
\hline
\end{tabular}

${ }^{1}$ Values expressed as mean \pm SEM $(n=6-8$ rats/group). Different superscript letters $a$ and $b$ within the same row indicate significant difference at $\mathrm{p}<0.05$ by one-way ANOVA followed by Tukey's test. Abbreviations: CSP, carp sarcoplasmic protein; MUFAs, monounsaturated fatty acids; PUFAs, polyunsaturated fatty acids; SFAs, saturated fatty acids. 
Table 6: Effect of consumption of different diets substituted with $10 \%$ kcal protein of carp sarcoplasmic protein, casein or whey protein for four weeks by growing female rats on hepatic lipid metabolism gene expression.

\begin{tabular}{ccccc}
\hline & \multicolumn{4}{c}{ Treatments $^{\mathbf{1}}$} \\
\cline { 2 - 5 } Measurements & CSP & Casein & Whey & No-Protein \\
\hline Lipogenesis & $14.03 \pm 3.91$ & $19.5 \pm 4.96$ & $29.64 \pm 5.99$ & $19.22 \pm 3.00$ \\
ChREBP & $2.4 \pm 0.57$ & $1.54 \pm 0.50$ & $2.08 \pm 0.51$ & $1.69 \pm 0.58$ \\
SREBP1c & $3.79 \pm 1.16$ & $1.68 \pm 0.82$ & $2.68 \pm 1.06$ & $2.69 \pm 0.76$ \\
SREBP2 & $0.19 \pm 0.06$ & $0.17 \pm 0.074$ & $0.38 \pm 0.11$ & $0.22 \pm 0.06$ \\
FAS & $2.16 \pm 0.75$ & $1.36 \pm 0.40$ & $2.05 \pm 0.39$ & $0.68 \pm 0.33$ \\
SCD-1 & & & \\
Lipolysis & $0.79 \pm 0.10$ & $1.31 \pm 0.35$ & $1.46 \pm 0.23$ & $1.185 \pm 0.24$ \\
PPAR $\alpha$ & $1.05 \pm 0.28$ & $0.9 \pm 0.32$ & $1.22 \pm 0.36$ & $0.55 \pm 0.13$ \\
PPAR $\gamma$ & $0.2 \pm 0.05$ & $0.095 \pm 0.02$ & $0.13 \pm 0.04$ & $0.44 \pm 0.16$ \\
HSL & & & \\
DGAT2 & $1.92 \pm 0.74$ & $1.13 \pm 0.21$ & $3.14 \pm 0.71$ & $1.35 \pm 0.69$ \\
LPL & $1.09 \pm 0.28^{\mathrm{ab}}$ & $1.24 \pm 0.25^{\mathrm{a}}$ & $0.78 \pm 0.19^{\mathrm{ab}}$ & $0.37 \pm 0.09^{\mathrm{b}}$ \\
MTTP & $1.29 \pm 0.48$ & $1.18 \pm 0.48$ & $1.31 \pm 0.42$ & $1.59 \pm 0.42$ \\
\hline Inflammation & & & & \\
COX-2 & $1.1 \pm 0.51$ & $0.26 \pm 0.19$ & $0.074 \pm 0.03$ & $0.43 \pm 0.28$ \\
IL-10 & $0.43 \pm 0.18$ & $0.18 \pm 0.07$ & $0.17 \pm 0.07$ & $0.24 \pm 0.12$ \\
NFאB & $1.06 \pm 0.21$ & $1.01 \pm 0.17$ & $1.25 \pm 0.32$ & $1.01 \pm 0.28$ \\
\hline
\end{tabular}

${ }^{1}$ Values expressed as mean \pm SEM ( $\mathrm{n}=6-8$ rats/group) of transcript abundance (A) of gene of interest relative to housekeeping genes $\beta$-actin and GAPDH. Different superscript letters $a$ and $b$ within the same row indicate significant difference at $p<0.05$ by one-way ANOVA followed by Tukey's test. Abbreviations: CSP, carp sarcoplasmic protein; ChREBP, carbohydrate-response element-binding protein; SREBP-1c, Sterol regulatory element-binding protein-1c; SREBP-2, Sterol regulatory element-binding protein-2; FAS, fatty acid synthase; SCD-1, Stearoyl-CoA desaturase-1; PPAR $\alpha$, Peroxisome proliferator-activated receptor alpha; PPAR $\gamma$, peroxisome proliferator-activated receptor gamma; HSL, hormone sensitive lipase; DGAT2, diacylglycerol O-acyltransferase 2; LPL, lipoprotein lipase; MTTP, microsomal triglyceride transfer protein; COX-2, cyclooxygenase 2 ; IL-10, interleukin 10 ; NFкB, nuclear factor kappa-light-chainenhancer of activated B cells; 
Table 7: Effect of the consumption of different diets substituted with $10 \%$ kcal protein of carp sarcoplasmic protein, casein or whey for four weeks on gonadal adipose tissue fatty acid composition and total lipid content.

\begin{tabular}{lcccc}
\hline & \multicolumn{4}{c}{ Treatments $^{\mathbf{1}}$} \\
\cline { 2 - 5 } Measurements & CSP & Casein & Whey & No-Protein \\
\hline SFAs (relative \%) & & & \\
Palmitic acid 16:0 & $24.54 \pm 0.80$ & $24.38 \pm 0.82$ & $24.45 \pm 0.48$ & $23.56 \pm 1.03$ \\
Stearic acid 18:0 & $3.91 \pm 0.24$ & $3.48 \pm 0.11$ & $3.90 \pm 0.24$ & $3.83 \pm 0.22$ \\
MUFAs (relative \%) & & & \\
Palmitoleic acid 16:1 & $5.54 \pm 0.30$ & $5.84 \pm 0.05$ & $5.41 \pm 0.27$ & $5.29 \pm 0.38$ \\
Oleic acid 18:1n9c & $29.29 \pm 1.43$ & $29.69 \pm 1.32$ & $30.81 \pm 0.91$ & $29.57 \pm 1.30$ \\
PUFAs (relative \%) & & & \\
Linoleic acid 18:2n6c & $20.72 \pm 0.72$ & $21.80 \pm 0.57$ & $22.59 \pm 0.86$ & $21.92 \pm 0.62$ \\
$\alpha-$ linoleic acid C18:3n3 & $2.17 \pm 0.19$ & $2.34 \pm 0.12$ & $2.31 \pm 0.08$ & $1.81 \pm 0.12$ \\
Arachidonic acid C20:4 & $0.00 \pm 0.00$ & $0.00 \pm 0.00$ & $0.00 \pm 0.00$ & $0.00 \pm 0.00$ \\
Eicosapentaenoic acid C20:5n3 & $0.00 \pm 0.00$ & $0.00 \pm 0.00$ & $0.00 \pm 0.00$ & $0.00 \pm 0.00$ \\
Docosahexaenoic acid 22:6n3 & $0.00 \pm 0.00$ & $0.00 \pm 0.00$ & $0.00 \pm 0.00$ & $0.00 \pm 0.00$ \\
\hline Total Lipid Content (\%) & $77.82 \pm 5.56$ & $73.66 \pm 4.10$ & $77.49 \pm 2.62$ & $66.57 \pm 1.99$ \\
\hline Values expressed as mean \pm SEM (n=6-8 rats/group). Different superscript letters a, b, and c \\
within the same row indicate significant difference at $\mathrm{p}<0.05$ by one-way ANOVA followed by \\
Tukey's test. Abbreviations: CSP, carp sarcoplasmic protein; MUFAs, monounsaturated fatty \\
acids; PUFAs, polyunsaturated fatty acids; SFAs, saturated fatty acids.
\end{tabular}


Table 8: Effect of consumption of different diets substituted with $10 \%$ kcal protein of carp sarcoplasmic protein, casein or whey protein for four weeks by growing female rats on lipid metabolism gene expression in gonadal adipose tissue.

\begin{tabular}{ccccc}
\hline & \multicolumn{4}{c}{ Treatments $^{\mathbf{1}}$} \\
\cline { 2 - 5 } Measurement & CSP & Casein & Whey & No-Protein \\
\hline Lipogenesis & & & \\
ChREBP & $1.33 \pm 0.37$ & $1.18 \pm 0.29$ & $1.22 \pm 0.38$ & $1.52 \pm 0.40$ \\
SREBP1c & $1.22 \pm 0.4$ & $1.18 \pm 0.32$ & $2.02 \pm 0.51$ & $1.95 \pm 0.51$ \\
SREBP2 & $1.38 \pm 0.37$ & $1.03 \pm 0.31$ & $1.29 \pm 0.22$ & $1.43 \pm 0.61$ \\
FAS & $2.18 \pm 0.69$ & $5.55 \pm 1.69$ & $5.3 \pm 1.43$ & $4.49 \pm 1.91$ \\
SCD-1 & $5.84 \pm 2.18$ & $3.42 \pm 1.21$ & $3.91 \pm 1.42$ & $1.59 \pm 0.64$ \\
Lipolysis & & & \\
PPAR $\alpha$ & $1.16 \pm 0.36$ & $1.50 \pm 0.48$ & $1.58 \pm 0.54$ & $2.72 \pm 0.67$ \\
PPAR $\gamma$ & $2.61 \pm 0.90$ & $2.27 \pm 0.77$ & $3.41 \pm 0.95$ & $2.36 \pm 0.71$ \\
HSL & $5.14 \pm 1.97$ & $3.84 \pm 1.76$ & $5.53 \pm 1.73$ & $6.62 \pm 2.44$ \\
\hline Storage and Transport & & & \\
DGAT & $0.25 \pm 0.05$ & $1.37 \pm 0.47$ & $1.88 \pm 0.63$ & $1.53 \pm 0.48$ \\
LPL & $2.07 \pm 0.74$ & $2.21 \pm 1.07$ & $3.3 \pm 1.13$ & $1.81 \pm 0.72$ \\
MTTP & $0.018 \pm 0.018$ & $0.74 \pm 0.41$ & $0.66 \pm 0.17$ & $0.34 \pm 0.09$ \\
\hline Inflammation & & & \\
COX-2 & $0.0033 \pm 0.001^{\mathrm{b}}$ & $0.017 \pm 0.0029^{\mathrm{a}}$ & $0.0081 \pm 0.0026^{\mathrm{ab}}$ & $0.00051 \pm 0.00025^{\mathrm{b}}$ \\
IL-10 & $0.0013 \pm 0.0003^{\mathrm{ab}}$ & $0.0025 \pm 0.0006^{\mathrm{a}}$ & $0.0019 \pm 0.0004^{\mathrm{ab}}$ & $0.00065 \pm 0.00025^{\mathrm{b}}$ \\
NFאB & $0.53 \pm 0.26$ & $0.77 \pm 0.38$ & $0.58 \pm 0.28$ & $0.35 \pm 0.09$ \\
\hline
\end{tabular}

${ }^{1}$ Values expressed as mean \pm SEM ( $n=6-8$ rats/group) of transcript abundance (A) of gene of interest relative to housekeeping genes $\beta$-actin and GAPDH. Different superscript letters $a$ and $b$ within the same row indicate significant difference at $p<0.05$ by one-way ANOVA followed by Tukey's test. Abbreviations: CSP, carp sarcoplasmic protein; ChREBP, carbohydrate-response element-binding protein; SREBP-1c, Sterol regulatory element-binding protein-1c; SREBP-2, Sterol regulatory element-binding protein-2; FAS, fatty acid synthase; SCD-1, Stearoyl-CoA desaturase-1; PPAR $\alpha$, Peroxisome proliferator-activated receptor alpha; PPAR $\gamma$, peroxisome proliferator-activated receptor gamma; HSL, hormone sensitive lipase; DGAT2, diacylglycerol O-acyltransferase 2; LPL, lipoprotein lipase; MTTP, microsomal triglyceride transfer protein; COX-2, cyclooxygenase 2 ; IL-10, interleukin $10 ; \mathrm{NF \kappa B}$, nuclear factor kappa-light-chainenhancer of activated B cells; 
Table 9: Effect of the consumption of different diets substituted with 10\% kcal protein of carp sarcoplasmic protein, casein or whey protein for four weeks on serum measurements of liver function enzymes, cholesterol, and triglycerides.

\begin{tabular}{lllll}
\hline Serum Measurements & CSP & Casein & Whey & No-Protein \\
\hline AST (U/L) & $223.71 \pm 34.01$ & $195.83 \pm 27.75$ & $129.20 \pm 20.27$ & $163.33 \pm 11.13$ \\
ALT (U/L) & $80.63 \pm 14.21$ & $67.71 \pm 7.48$ & $63.71 \pm 10.22$ & $64.57 \pm 5.99$ \\
VLDL-C/LDL-C (uM) & $38.62 \pm 7.37$ & $38.83 \pm 6.65$ & $39.07 \pm 8.07$ & $19.54 \pm 2.46$ \\
HDL-C (uM) & $14.02 \pm 4.48$ & $14.31 \pm 3.94$ & $20.05 \pm 8.35$ & $11.25 \pm 3.77$ \\
Total Cholesterol (uM) & $52.64 \pm 9.30$ & $53.15 \pm 5.97$ & $59.12 \pm 6.13$ & $30.79 \pm 4.49$ \\
Triglycerides (mg/dl) & $100.95 \pm 9.95$ & $98.09 \pm 10.12$ & $112.78 \pm 8.77$ & $95.31 \pm 12.99$ \\
\hline
\end{tabular}

${ }^{1}$ Values expressed as mean \pm SEM $(n=6-8$ rats/group). Different superscript letters $a, b$, and $c$ within the same row indicate significant difference at $p<0.05$ by one-way ANOVA followed by Tukey's test. Abbreviations: CSP, carp sarcoplasmic protein; AST, aspartate aminotransferase; ALT, alanine aminotransferase; VLDL-C, very low density lipoprotein cholesterol; LDL-C, low density lipoprotein cholesterol; HDL, high density lipoprotein. 


\section{Chapter VI}

\section{Silver Carp (Hypophthalmichthys molitrix) Sarcoplasm Protein Intake Minimally Alters the Global Hepatic Transcriptome in Young Female Sprague-Dawley Rats Fed a Low Protein Diet}

Derek Warren $^{1}$, Vagner A. Benedito ${ }^{3}$, Ayad Alawadi ${ }^{1}$, R. Chris Skinner ${ }^{2}$, Kristen Matak ${ }^{1}$, Janet C. Tou $^{1}$

${ }^{1}$ Division of Animal and Nutritional Sciences, ${ }^{2}$ Department of Biology, ${ }^{4}$ Division of Plant and Soil Sciences, West Virginia University, Morgantown, WV

*Corresponding Author

Janet C. Tou, PhD, P.O. Box 6108, Animal and Nutritional Sciences, West Virginia University, Morgantown, WV 26506, USA.

Phone: (304)293-1919; Fax: (304)293-2232

Email: janet.tou@mail.wvu.edu

Choice of journal where article should appear: Journal of Functional Foods 


\begin{abstract}
Whey-based infant formulas have been reported to increase body weight gain and obesity risk. Protein content in infant formulas are often higher than human breastmilk resulting in elevated secretion of insulin like growth factor-1 (IGF-1) leading to anabolic metabolism. Previously, we determined water-soluble carp sarcoplasmic proteins (CSP) recovered in wash water to be a safe, with nutritional and functional values comparable to milk proteins, casein and whey protein. The objective of this study to investigate phenotypic and hepatic transcriptome responses due to low protein $(10 \% \mathrm{kcal})$ diets consisting of CSP or milk proteins. Young (age 28 days) female Sprague-Dawley rats were randomly assigned ( $\mathrm{n}=8$ rats/group) to standard purified diet providing $10 \%$ CSP, casein, whey protein isolate or a protein-free diet. Following 4 weeks of feeding, liver total RNA was extracted from hepatic tissue samples. Total RNA samples of the highest quality ( $\mathrm{n}=4$ rats/groups) underwent RNA sequencing. RNA sequencing reads were aligned, mapped, and assembled prior to differential gene expression. Transcripts per million for genes involved in branch chain amino acid (BCAA) metabolism, IGF-1 signaling pathway, and lipid metabolism were calculated for analysis. Whey protein isolate had the highest BCAA content compared to casein and CSP. This corresponded with greater $(\mathrm{p}<0.05)$ final body weight and gonadal fat pad weight in whey protein compared to CSP and casein-fed rats. Consumption of the protein-free diet resulted in the greatest number $(1,814)$ of differentially expressed genes compared to rats fed casein. Rats fed protein-free diet were separated from CSP, casein, and whey protein-fed rats which were arbitrarily clustered together. Among protein diets, abundance of IGF-1 transcripts were greater $(\mathrm{p}<0.05)$ in rats consuming CSP and whey protein. However, there were no differences in gene transcript abundance in BCAA metabolism and the IGF-1 signaling cascade among diet groups. Collectively, results indicate diets with reduced
\end{abstract}


protein content $(10 \% \mathrm{kcal})$ may not be sufficient to cause significant alterations to hepatic transcriptome. However, greater expression of IGF-1 can affect extrahepatic nutrient storage in adipose tissue. 


\section{Introduction}

According to the Food and Agriculture Organization of the United Nations (FAO), the global consumption of fish and other aquatic animals has quadrupled in the past 50 years. However, global fisheries are operating close to maximal levels with risk of depleting fish stock (FAO, 2016). The FAO reported 3.3 percent reduction of aquaculture industries while the global human population is expected to exceed 10 billion by 2050 (FAO, 2016). To overcome limitations of natural resources, solutions need to be developed such as, utilization of less desirable fish species. Silver carp (Hypophthalmichthys molitrix) brought to the United States in the 1970s were unintentionally introduced to the Mississippi River due to flooding. Since their introduction, silver carp have become an invasive species (Chick 2001). Despite their abundance, silver carp are underutilized due to their boniness making consumption and processing difficult. However, silver carp could be processed into a nutritious, alternative protein source.

All fish exceed the requirement of having more than $12 \%$ energy from protein to be considered high in protein and are a good source of essential amino acids (Ruxton, 2011). Warren et al. (2018) investigated the recovery, drying, and in vitro characteristics of a proteinrich silver carp sarcoplasm protein (CSP) powder. Results indicated no differences between the CSP and milk proteins, whey and casein. Whey and casein are used in protein supplements and infant formulas with long-term commercial success.

Ong and others (2009) reported greater body weight gains in formula-fed infants compared to infants fed human milk due to increased insulin like growth factor 1 (IGF-1) and insulin excretion. IGF-1 is a protein synthesized and secreted by the liver with major regulatory roles in growth and metabolism by mediating the effects of growth hormone $(\mathrm{GH})$. GH synthesis and secretion of IGF-1 is dependent on nutritional status and hormones such as insulin (Daughaday 
and Rotwin, 1989). Diets low in protein have been shown to decrease plasma concentrations of IGF-1 in growing pigs (Deng et al., 2007). Dietary branch chain amino acids (BCAA) have been reported to induce IGF-1 excretion; however, the mechanism of action has not been well-studied. Wan et al. (2017) reported greater expression of IGF-1 from amino acid supplementation as a result of an interaction between mammalian target of rapamycin (mTOR), an important intracellular sensor for cell growth and autophagy, and peroxisome proliferator-activated receptor gamma (PPAR $\gamma$ ), a transcription factors involved in the regulation of lipolysis. However, more mechanistic studies are needed.

Compared to human milk, infant formulas often have higher protein content and is suggested to contribute to risk of obesity (Tang, 2018). Weight gain during the first year of life is one of the best indicators of later risk of obesity (Ong \& Loos, 2006). This led to suggestions for infant formulas to lower amounts of protein and use high quality proteins to reduced risk of developing obesity later in life (Koletzko et al., 2009). Protein quality and physiological effects of proteins varies depending on its source. Song and others (2016) reported protein from beef, chicken, pork and carp sources in the recommended amount (18\% by weight) for seven days resulted in distinct gene expression and physiological responses. Carp consumption was shown to downregulate genes regulating fatty acid oxidation and the synthesis of bile acids, triglycerides, and cholesterol. Therefore, the objective of this study was to investigate distinct phenotypic and hepatic transcriptome responses due to feeding low protein $(10 \% \mathrm{kcal})$ diets consisting of CSP and milk proteins, casein and whey, in an animal model using growing rats.

\section{Materials and Methods}

\subsection{Animals and Diets}

Immature (age 28 days) female Sprague-Dawley rats $(n=32)$ were purchased from Charles River (Worcester, MA) and individually housed in metabolic cages for 4 weeks. 
Following an acclimation period of 7-days, rats $(n=32)$ were randomly assigned to four experimental groups ( $\mathrm{n}=8$ rats/group) of purified standard rodent diet AIN-93G (American Institute of Nutrition-93Growth) consisting of different sources of protein: (1) AIN-93G with $10 \%$ kcal CSP for 4 weeks, (2) AIN-93G with 10\% kcal casein for 4 weeks, (3) AIN-93G with $10 \% \mathrm{kcal}$ whey protein for 4 weeks or, (4) AIN-93G with $10 \% \mathrm{kcal}$ casein for 2 weeks followed by protein free diet for 2 weeks. Table 1 shows diet ingredients and composition. All experimental diets were isocaloric $(3.7-3.8 \mathrm{kcal} / \mathrm{g})$ with the only difference being protein source. All animal procedures were performed in accordance with National Research Council for the Care and Use of Laboratory Animals guidelines and approved by West Virginia University's Animal Care and Use Committee (National Research Council, 2011).

All diets as well as protein sources, casein and whey protein, were purchased from Envigo-Teklad (Madison, WI). Diets were stored at $-20^{\circ} \mathrm{C}$ between feedings, Distilled deionized water $\left(\mathrm{ddH}_{2} \mathrm{O}\right)$ was provided ad libitum and replaced weekly. Rats were provided $20 \mathrm{~g}$ diet daily until normal diet consumption was established. Rats were then peer fed $16 \pm 0.20 \mathrm{~g} \operatorname{diet} / \mathrm{d}$. Following 4 weeks of feeding, rats were fasted overnight ( $12 \mathrm{~h})$ and euthanized by carbon dioxide inhalation. The liver was removed, perfused, weighed, flash frozen in liquid nitrogen, and stored at $-80^{\circ} \mathrm{C}$ for later analysis.

\subsection{RNA isolation and RNA Sequencing}

Total RNA was extracted from frozen hepatic tissue $(50 \mathrm{mg})$ using the Zymo Research mRNA Isolation Kit (Irvine, CA, USA) according to the manufacturer's instruction for total RNA isolation. Isolated RNA was treated with DNaseI with a TURBO DNA-free kit (Applied Biosystems, Foster City, CA, USA) and sent for quality assurance via bioanalyzer (Agilent, Santa Clara, CA). 
RNA samples with the highest quality ( $\mathrm{RIN} \geq 6.8)$ from each experimental group $(\mathrm{n}=4)$ were selected for sequencing. Selected RNA samples were sent to Novogene Corporation (Chula Vista, CA, USA) for cDNA library construction ( $300 \mathrm{bp}$ ) and RNA sequencing analysis (Illumina Platform PE150; Q30 $\geq 80 \% ; 20 \mathrm{M}$ raw reads/sample). Briefly, data was imported into the Cyverse Discovery Environment (Cyverse, Tucson, AR, USA). RNA-Seq reads were aligned with RMTA v2.6.3 workflow by mapping reads to the Ensembl reference genome (vRnor_6) with HISAT2 then assembled using Stringtie and count reads using feature counts with default parameters.

Differential gene expression was conducted using the DESeq2 package R Studio to read count tables. Similar to Song et al. (2016), experimental groups were compared to casein as a control to simplify the interpretation of the differential expression results. Results from DESeq2 were imported into Ingenuity Pathway Analysis (Qiagen Inc, Germantown, MD, USA). The enrichment map generated using the Comparison Analysis plugin within the IPA software with the default settings with gene sets that passed conservative significant thresholds $(\mathrm{p}<0.05$, False Discovery Rate $(\mathrm{FDR})<0.10)$. A hierarchical cluster analysis heat map was produced using the feature counts with the R studio pheatmap package following log transformation. Transcripts per million for genes involved in the BCAA metabolism, IGF-1 signaling pathway, and lipid metabolism were calculated using Kallisto-0.42.3 application in the Cyverse discovery environment. Transcripts of interest were chain amino acid amino transferase (BCAA-AT), branch chain ketoacid hydrogenase (BCKA-DH), IGF-1, insulin like growth factor 1 receptor (IGF-1R), ras homolog enriched in brain (RHEB), mTOR, sterol regulatory element-binding protein-2 (SREBP-2), and peroxisome proliferator-activated receptor gamma (PPAR $\gamma$ ).

\subsection{Statistical analysis}


A completely randomized design was used in the animal feeding study with $n=8$ rats per experimental diet group. Results are expressed as mean \pm standard error of the mean. One-way ANOVA was used to determine differences among diet treatment groups. Post-hoc multiple comparison tests were performed using Tukey's test with treatment differences considered significant at $\mathrm{p}<0.05$ and tendency at $\mathrm{p}=0.08$. Statistical analyses were performed using JMP 12.2 statistical software package (SAS Institute, Cary, NC).

\section{Results}

\subsection{Dietary Amino Acid Profile and Growth}

Whey protein isolate had the greatest BCAA content at $262 \mathrm{mg} / \mathrm{g}$ protein compared to casein (222 mg/g protein) and CSP (148 mg/g protein) (Table 2). Leucine was the most abundant BCAA for the CSP, casein, and whey protein diets at $63 \mathrm{mg} / \mathrm{g}$ protein, $94 \mathrm{mg} / \mathrm{g}$ protein, and $143 \mathrm{mg} / \mathrm{g}$ protein, respectively.

As shown in Figure 1, whey protein-fed rats had greater $(\mathrm{p}<0.05)$ final body weight compared to rats fed CSP and casein. There were no body weight differences between casein and CSP-fed rats. Rats fed casein followed by a protein deficient diet for two weeks had the lowest (p $<0.05)$ final body weight. Rats were peer-fed therefore there were no differences in total diet intake or caloric intake among protein diet groups.

Illustrated in Table 3, rats fed whey protein had greater $(\mathrm{p}<0.05)$ gonadal fat pad weight compared to CSP and protein-free fed rats. Liver weights were greater $(\mathrm{p}<0.05)$ in rats fed $10 \%$ protein as CSP, casein, and whey protein compared to the protein-free group. However, following body weight correction, weight difference was no longer statistically significant.

\subsection{RNA sequencing}


RNA sequencing resulted in 21,629 transcripts expressed in rat hepatic tissue (Table 4). Whey protein-fed rats had more transcripts expressed $(16,994)$ compared to rats fed CSP, casein or protein-free diet. There were 6 differentially expressed transcripts when all diet groups were compared. Therefore, casein was used as a control to simplify the interpretation of the differential expression results. There were minimal differentially expressed transcripts when CSP and whey protein supplementation were compared to casein.

Consumption of the protein-free diet for 2 weeks resulted in the greatest number $(1,814)$ of differentially expressed genes when compared to casein-fed rats. The hierarchical cluster analysis of expressed transcripts is provided in Figure 2. Rats fed protein free diet were separated from rats fed CSP, casein, and whey protein which were arbitrarily clustered together. Subsequently, there were no differences in the comparison pathway analysis of differentially expressed genes among protein fed rats (Figure 3). Rats fed protein free diet resulted in the enhancement of multiple pathways; however, PPAR and mTOR pathways were not enriched.

\subsection{IGF-1 Pathway}

Shown in Figure 5, there were no differences in transcript expression of genes involved in metabolism of BCAA (BCAA-AT, BCKA-DH). Abundance of IGF-1 transcripts were greater $(\mathrm{p}<0.05)$ in rats consuming CSP and whey protein. However, there were no differences in transcript abundance of genes involved in IGF-1 signaling (IGF-1R, RHEB, mTOR,), lipogenesis (SREBP-2), and lipolysis (PPAR $\gamma$ ).

\section{Discussion}

\subsection{Dietary Amino Acid Profile and Growth}

In the current study, growing rats fed a protein deficient ( $0 \% \mathrm{kcals})$ diet for 2 weeks had the lowest body weight. Among protein diets, rats fed whey protein had significantly greater 
final body weight compared to rats fed either CSP or casein. All experimental diets were isocaloric and adjusted for nutrients resulting in no differences in dietary lipid profile or content and therefore, the only difference was protein type. Comparing amino acid profiles of experimental diets showed whey protein diet had the greatest leucine and isoleucine content (Warren et al., 2018). BCAAs (leucine, isoleucine, and valine) have been reported to promote adipogenesis by stimulating insulin and IGF-1 (Melnik, 2012). In the current study, fat deposition depended on the protein source with greater gonadal adipose weight in growing rats consuming whey protein (Table 3). Others have suggested high whey protein consumption contributes to obesity and weight gain in infant (Tang, 2018; Koletzko et al., 2009). Investigating the effect of protein sources on fat deposition is important to further investigate since weight gain during early life has been reported to be one of the best indicators of later risk of obesity (Ong \& Loos, 2006).

The current study results suggest differences in phenotype were a result of the different protein sources. Leucine and isoleucine play an important role in the synthesis of proteins and other nitrogenous compounds, including transcription factors involved in lipid metabolism regulation (Nie et al., 2018). Therefore, RNA sequencing was used to identify the distinct hepatic transcriptome responses leading to the phenotype differences in growing rats fed low protein (10\% kcal) diets provided as CSP or milk proteins, casein and whey.

\subsection{RNA Sequencing}

Minimal differences were identified among rat consuming different protein diet. The results suggest CSP, casein, and whey protein had comparable effects on the hepatic transcriptome. In contrast, Song et al., (2016) reported transcriptome alterations were not significantly different in rats fed $18 \% \mathrm{kcal}$ protein diets sourced from beef, chicken, pork and 
carp compared to casein as a control. Carp protein consumption had the greatest effects on gene sets describing fatty acid oxidation and the synthesis of bile acids, triglycerides, and cholesterol. No differences were reported in BCAAs and sulfur amino acids (cysteine and methionine) content amount the meat protein powders. Since lipid profiles were not assessed the observed alterations to lipid metabolism may have been a result of different dietary fatty acid. Our study indicates reduced protein $(10 \% \mathrm{kcal})$ diets with similar fatty acid profiles (Supplemental Table 1$)$ may not be sufficient to cause significant alterations to the hepatic transcriptome.

In our study, rats provided a protein free diets for two weeks altered the hepatic transcription, as evident by the hierarchical cluster analysis and comparative pathway analysis. Particularly, isoleucine and valine degradation pathways were enriched in rats fed the protein free diet. Isoleucine and valine are branched chain as well as essential amino acids. Results suggest catabolism of BCAA may have been enhanced to compensate for the synthesis of other amino acids missing in the diet. Therefore, transcripts of genes involved in BCAA catabolism were assessed.

\subsection{Genes of Interest}

Catabolism of BCAA is important to maintain numerous homeostatic processes such as protein turnover and anabolism, fatty acid oxidation, and immune function (Knerr et al., 2012). BCAA metabolism occurs in the mitochondrial matrix with distinct pathways for each BCAA (McCalley et al., 2019). Following transport into the mitochondria, BCAAs undergo deamination via BCAA amino transferase (BCAA-AT) producing 2-oxo-branched chain organic acids. Once deamination occurs, BCAA alpha-keto acid dehydrogenase (BCAA-DH) produces branchedchain acyl-coenzymes through oxidative decarboxylation. These enzymes are common in catabolism of all three BCAAs. Production of acetoacetate, acetyl-CoA, and propionyl-CoA via 
specific acyl-CoA dehydrogenases is the final step in BCAA catabolism (Knerr et al., 2012).

Products of BCAA catabolism can then entering the Kreb cycle for energy production. However, end products of leucine and isoleucine catabolism are substrates for fatty acid synthesis (Lehninger et al., 2013). Whey protein had higher leucine and isoleucine content which may have contributed to greater adiposity. However, no differences were identified in transcript abundance in BCAA-AT or BCAA-DH among experimental diets suggesting minimal differences in BCAA catabolism among diet groups.

Previous research reported an increase secretion of IGF-1 potentiates greater body weight gains in infants fed whey-based formulas (Ong et al.,2009). PPAR $\gamma$ was reported to be crucial for gene expression of IGF-1 and is induced by amino acid concentration (Wan et al., 2017). PPAR $\gamma$ is one of a group of transcription factors that regulate metabolism cell, development, and differentiation (Ahmadian et al., 2013; Wright et al. 2014; Reynolds et al., 2015). Numerically, PPAR $\gamma$ expression was lowest in rats fed whey protein. Conversely, rats consuming whey protein and CSP diets resulted in greater $(\mathrm{p}<0.05)$ IGF-1 transcript abundance compared to rats fed the protein free diet. Numerically, rats consuming whey protein had more IGF-1 transcripts. No differences were identified among diet groups when downstream molecules in the IGF-1 pathway such as mTOR, an amino acid sensor for promoting growth and development, as well as SREBP-2, a regulator of de novo lipogenesis, were investigated (Jewell et al, 2013; Strable et al., 2010). Results indicate IGF-1 expression, secretion and signaling pathway may have additional modulators in the liver.

\section{Conclusion}

In conclusion, results showed feeding a low protein (10\% kcal) diet consisting of whey protein potentiates higher body weight and adipose deposition in growing rats. However, this 
district phenotypic response was not imitated in the hepatic transcriptome indicated by negligible difference among protein-fed rats. Further, minimal differences in transcriptome abundance of gene modulating BCAA catabolism and the IGF-1 signaling pathway were identified among diet groups. However, IGF-1 transcript abundance was enhanced in CSP and whey protein-fed rats. Collectively, results indicate diets with reduced protein content $(10 \% \mathrm{kcal})$ may not be sufficiently deficient to cause significant alterations to hepatic transcriptome. However, the greater expression of IGF-1 may affect nutrient storage in extrahepatic tissues such as adipose tissue. 


\section{References}

1. Ahmadian M, Suh JM, Hah N, Liddle C, Atkins AR, Downes M, et al. (2013). PPAR gamma signaling and metabolism: the good, the bad and the future. Nat. Med., 19(5), 557-66. doi: 10.1038/nm.3159PMID: 23652116

2. Chick J. (2001) Invasive Carp in the Mississippi River Basin. Sci., 292, 2250-2251. doi: $10.1126 /$ science. 292.5525 .2250

3. Daughaday WH, Rotwein P. (1989). Insulin-like growth factors I and II. Peptide, messenger ribonucleic acid and gene structures, serum, and tissue concentrations. Endocr. Rev., 10(1), 68-91. doi: 10.1210/edrv-10-1-68 PMID: 2666112

4. Deng D, Li AK, Chu WY, Huang RL, Li TJ, Kong XF, et al. (2007). Growth performance and metabolic responses in barrows fed low-protein diets supplemented with essential amino acids. Livest. Sci., 2007, 109(1-3), 224-227.

5. FAO, Food and Agriculture Organization of the United Nations. (2016). The State of World Fisheries and Aquaculture, 2016. Rome, Italy: Author. Retrieved from https://www.fao.org/3/a-i5555e.pdf.

6. Jewell JL, Russell RC, Guan KL. (2013). Amino acid signaling upstream of mTOR. Nat. Rev. Mol. Cell. Biol., 14(3), 133-139. doi: 10.1038/nrm3522 PMID:23361334

7. I. Knerr, N. Weinhold, J. Vockley, K.M. Gibson (2012). Advances and challenges in the treatment of branched-chain amino/keto acid metabolic defects J. Inherit. Metab. Dis., $35,29-40$.

8. Koletzko, B., von Kries, R., Closa, R., Escribano, J., Scaglioni, S., Giovannini, M., Beyer, J., Demmelmair, H., Gruszfeld, D., Dobrzanska, A., Sengier, A., Langhendries, J., P., Rolland Cachera M., F., Grote, V. (2009). Lower Protein in Infant Formula is 
Associated with Lower Weight up to age 2 y: a Randomized Clinical Trial. Amer. J. of Clin. Nutri., 89, 1836-1845. http://doi.org/10.3945/ajcn.2008.27091.

9. Lehninger, A., Cox, M., Nelson, D. (2011). Lehninger Principles of Biochemistry. W.H. Freeman, New York

10. McCalley, Stephen \& Pirman, David \& Clasquin, Michelle \& Johnson, Kendall \& Jin, Shengfang \& Vockley, Jerry. (2019). Metabolic analysis reveals evidence for branched chain amino acid catabolism crosstalk and the potential for improved treatment of organic acidurias. Mol. Genet. and Meta., 128. 10.1016/j.ymgme.2019.05.008.

11. Melnik, B.C. (2012). Excessive Leucine-mTORC1-signalling of Cow Milk-based Infant Formula: The Missing Link to Understand Early Childhood Obesity. J. Obes., 2012, 197653. http://doi.org/10.1155/2012/197653.

12. National Research Council. (2011) Guide for the care and use of laboratory animals. The Nat. Acad. Press., 8, 11-65. doi: 10.17226/12910

13. Nie, C., He, T., Zhang, W., Zhang, G., Ma, X. (2018). Branch Chain Amino Acids: Beyond Nutrition Metabolism, Inter. J. Mol. Sci., 19(4). pii: E954. http://doi.org/10.3390/ijms19040954.

14. Ong K., Loos R. (2006). Rapid infancy weight gain and subsequent obesity: systematic reviews and hopeful suggestions. Acta. Paediatr., 95(8), 904-8.

15. Ong, K., Langkamp, M., Ranke, M., Whitehead, K., Hughes, I., Acerini, C., Dunger. D. (2009). Insulin-like growth factor I concentrations in infancy predict differential gains in body length and adiposity: the Cambridge Baby Growth Study. Ameri. J. Clin. Nutr., 90(1), 156-161, https://doi.org/10.3945/ajcn.2008.27408 
16. Reynolds MR, Clem BF. (2015). Troglitazone suppresses glutamine metabolism through a PPAR-independent mechanism. Biolog. Chem., Epub 2015/04/16.

17. Song, Shangxin \& Hooiveld, Guido \& Li, Mengjie \& Zhao, Fan \& Zhang, Wei \& Xu, Xing-Lian \& Muller, Michael \& Li, Chunbao \& Zhou, G.H.. (2016). Distinct physiological, plasma amino acid and liver transcriptome responses to purified dietary beef, chicken, fish, and pork proteins in young rats. Mol. Nutri. Food. Res., 60. 11991205. https://doi.org/10.1002/mnfr.201500789.

18. Strable, M.S.; Ntambi, J.M. (2010). Genetic control of de novo lipogenesis: Role in dietinduced obesity. Crit. Rev. Biochem. Mol. Biol., 45, 199-214.

19. Tang M. (2018). Protein Intake during the First Two Years of Life and Its Association with Growth and Risk of Overweight. Intern. J. Enviro. Res. \& Pub. Health., 15(8), E1742. http://doi.org/10.3390/ijerph15081742.

20. Wang, Songbo \& Zhuang, Lu \& Xing, Kongping \& Zhang, Mengyuan \& Zhu, Xiaotong \& Wang, Lina \& Gao, Ping \& Xi, Qianyun \& Jiajie, Sun \& Zhang, Yong-Liang \& Li, Tiejun \& Shu, Gang \& Jiang, Qingyan. (2017). Dietary protein-induced hepatic IGF-1 secretion mediated by PPAR $\gamma$ activation. PLOS ONE., 12. e0173174. 10.1371/journal.pone.0173174.

21. Warren D, Paker I, Jaczynski J, \& Matak KE. (2018). Nutritional Quality and Physical Characteristics of Soluble Proteins Recovered from Silver Carp. J. Food. Sci., 83(7), 1970-1979. http://doi.org/10.1111/1750-3841.14170

22. Wright MB, Bortolini M, Tadayyon M, Bopst M. (2014). Minireview: Challenges and opportunities in development of PPAR agonists. Mol. Endocrinol., 28(11):1756-68. doi: 10.1210/me.2013-1427 PMID:25148456 


\section{Figures and Tables}

Table 1: Nutritional level and ingredient composition of experimental protein diets.

\begin{tabular}{|c|c|c|c|c|}
\hline Items & CSP & Casein & Whey & No-Protein \\
\hline \multicolumn{5}{|c|}{ Selected Nutrient Information ${ }^{1}$} \\
\hline Protein $(\%)$ & 10 & 10 & 10.3 & 0 \\
\hline Carbohydrate $(\%)$ & 66.9 & 67.8 & 68.1 & 78.1 \\
\hline Fat $(\%)$ & 7 & 7.1 & 7 & 7 \\
\hline Energy (kcal/g) & 3.7 & 3.8 & 3.8 & 3.8 \\
\hline \multicolumn{5}{|l|}{ Ingredient $(\mathrm{g} / \mathrm{kg})^{1}$} \\
\hline Whey Protein Isolate & - & - & 111 & - \\
\hline Casein & - & 115 & - & - \\
\hline Carp Protein & 131.5 & - & - & - \\
\hline Corn Starch & 482.236 & 492.036 & 495.286 & 605.986 \\
\hline Maltodextrin & 132 & 132 & 132 & 132 \\
\hline Sucrose & 100 & 100 & 100 & 100 \\
\hline Soybean Oil & 66.5 & 70 & 70 & 70 \\
\hline Cellulose & 50 & 50 & 50 & 50 \\
\hline Mineral Mix & 13.4 & 13.4 & 13.4 & 13.4 \\
\hline Calcium Phosphate & 0.75 & 9.8 & 13.2 & 13.4 \\
\hline Calcium Carbonate & 11.1 & 5.25 & 2.6 & 2.7 \\
\hline Vitamin Mix & 10 & 10 & 10 & 10 \\
\hline Choline Bitartate & 2.5 & 2.5 & 2.5 & 2.5 \\
\hline TBHQ & 0.014 & 0.014 & 0.014 & 0.014 \\
\hline
\end{tabular}

Abbreviations: CSP, carp sarcoplasmic protein; TBHQ, Tertiary butylhydroquinone

${ }^{1}$ Received from Envigo-Teklad (Madison, WI) 
Table 2: Amino analysis of carp sarcoplasmic protein, casein, and whey protein powders

\begin{tabular}{|c|c|c|c|}
\hline & CSP1 $^{1}$ & Casein $^{2}$ & Whey $^{2}$ \\
\hline \multicolumn{4}{|c|}{ Essential Amino Acid (mg/g protein) } \\
\hline Valine & $47.21 \pm 0.18$ & 70 & 56 \\
\hline Leucine & $62.96 \pm 0.26$ & 94 & 143 \\
\hline Isoleucine & $38.23 \pm 0.14$ & 58 & 63 \\
\hline Threonine & $32.13 \pm 0.21$ & 44 & 53 \\
\hline Methionine + Cysteine & $26.35 \pm 0.27$ & 31 & 64 \\
\hline Phenylalanine + Tyrosine & $64.74 \pm 0.65$ & 105 & 80 \\
\hline Lysine & $74.46 \pm 0.44$ & 82 & 112 \\
\hline Histidine & $43.62 \pm 0.24$ & 29 & 20 \\
\hline Tryptophan & $11.49 \pm 0.16$ & 12 & 24 \\
\hline Arginine & $37.72 \pm 0.21$ & 39 & 30 \\
\hline Total Essential Amino Acid & 438.91 & 506 & 563 \\
\hline \multicolumn{4}{|c|}{ Non-essential amino acids (mg/g protein) } \\
\hline Alanine & $48.86 \pm 0.22$ & 32 & 57 \\
\hline Glycine & $51.07 \pm 0.27$ & 19 & 18 \\
\hline Serine & $28.17 \pm 0.28$ & 56 & 45 \\
\hline Proline & $23.31 \pm 1.05$ & 84 & 45 \\
\hline Aspartic Acid & $81.58 \pm 0.42$ & 71 & 125 \\
\hline Glutamic Acid & $83.74 \pm 0.48$ & 229 & 176 \\
\hline Tyrosine & $23.21 \pm 0.18$ & 54 & 42 \\
\hline Cysteine & $9.88 \pm 0.03$ & 4 & 40 \\
\hline Taurine & $25.98 \pm 0.45$ & ND & ND \\
\hline Total NEAA & 375.8 & 549 & 548 \\
\hline
\end{tabular}




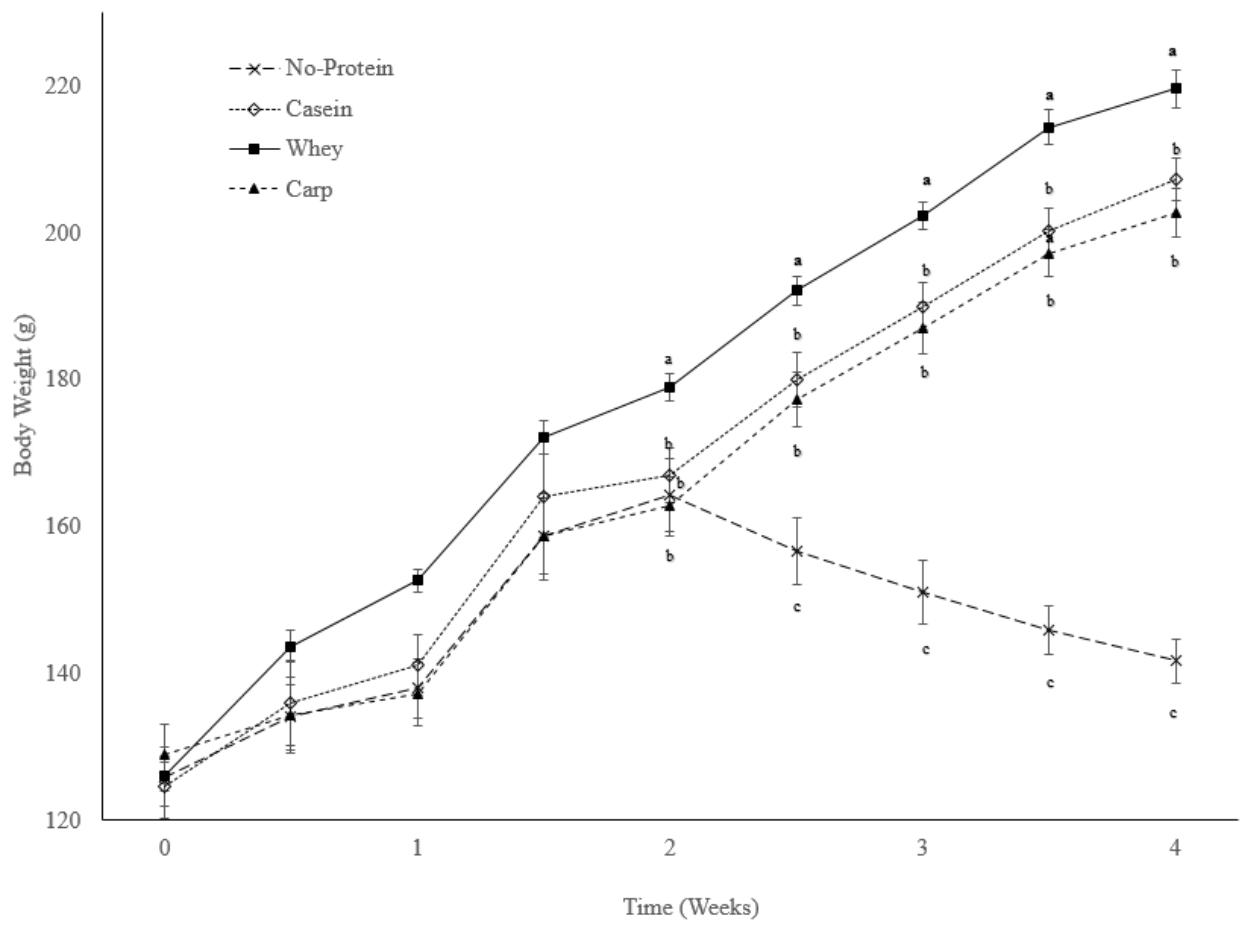

Figure 1: Body weights of female rats fed $10 \%$ protein diets consisting of carp sarcoplasmic protein (Carp), casein, whey protein isolate, or 2 weeks on $10 \%$ casein diet followed by a no-protein diet. Values are mean \pm SEM of $n=8$ rats/group. Letters ( $a, b, c)$ shows significant difference at $\mathrm{p}<0.05$ determined by ANOVA followed by Tukey's HSD. 
Table 3: Effect of the consumption of different diets substituted with $10 \%$ kcal protein of carp sarcoplasmic protein, casein or whey for four weeks on growth parameters of growing female rats.

\begin{tabular}{|c|c|c|c|c|}
\hline \multirow[b]{2}{*}{ Growth Parameters } & \multicolumn{4}{|c|}{ Treatment $^{1}$} \\
\hline & CSP & Casein & Whey & No-Protein \\
\hline Caloric intake (kcal) & $1664.91 \pm 43.78^{\mathrm{a}}$ & $1678.26 \pm 26.57^{a}$ & $1749.87 \pm 43.77^{\mathrm{a}}$ & $1446.24 \pm 43.78^{b}$ \\
\hline Final body weight (g) & $202.85 \pm 3.33^{\mathrm{b}}$ & $207.26 \pm 2.89^{\mathrm{b}}$ & $219.66 \pm 2.66^{\mathrm{a}}$ & $141.70 \pm 2.98^{\mathrm{c}}$ \\
\hline Total body weight gain (g) & $73.93 \pm 1.71^{\mathrm{b}}$ & $82.68 \pm 4.04^{\mathrm{ab}}$ & $93.69 \pm 3.11^{\mathrm{a}}$ & $15.82 \pm 2.75^{\mathrm{c}}$ \\
\hline Liver weight $(\mathrm{g})$ & $8.45 \pm 0.47^{\mathrm{a}}$ & $8.48 \pm 0.35^{\mathrm{a}}$ & $9.54 \pm 0.52^{\mathrm{a}}$ & $5.4 \pm 0.19^{b}$ \\
\hline Relative liver weight (g / g bwt.) & $4.15 \pm 0.18$ & $4.10 \pm 0.14$ & $4.18 \pm 0.17$ & $3.89 \pm 0.15$ \\
\hline Gonadal fat pad weight (g) & $2.62 \pm 0.46^{\mathrm{b}}$ & $3.26 \pm 0.53^{\mathrm{ab}}$ & $5.10 \pm 0.68^{\mathrm{a}}$ & $1.47 \pm 0.35^{\mathrm{b}}$ \\
\hline Relative gonadal fat pad (g/g bwt) & $1.28 \pm 0.22^{\mathrm{b}}$ & $1.57 \pm 0.25^{\mathrm{ab}}$ & $2.31 \pm 0.31^{\mathrm{a}}$ & $1.06 \pm 0.25^{\mathrm{b}}$ \\
\hline
\end{tabular}

${ }^{1}$ Values expressed as mean \pm SEM $(n=6-8$ rats/group). Different superscript letters $a, b$, and c within the same row indicate

significant difference at $\mathrm{p}<0.05$ by one-way ANOVA followed by Tukey's HSD. Abbreviations: CSP, carp sarcoplasmic protein. 
Table 4: Statistics of transcript expression

\begin{tabular}{lcc}
\hline \multicolumn{1}{c}{ Class } & $\#^{\mathbf{1}}$ & $\mathbf{\%}^{\mathbf{2}}$ \\
\hline Total Transcripts & 32883 & 100 \\
Expressed Transcripts & 21629 & 65.78 \\
Expressed in CSP & 16692 & 77.17 \\
Expressed in Casein & 16764 & 77.51 \\
Expressed in Whey & 16994 & 78.57 \\
Expressed in No Protein & 16947 & 78.35 \\
\hline Differentially expressed transcripts $(p<0.05 ;$ & & \\
$q<0.05)$ & & \\
$\quad$ Global & 6 & 0.03 \\
$\quad$ Carp to Casein & 25 & 0.12 \\
$\quad$ Whey to Casein & 7 & 0.03 \\
$\quad$ No Protein to Casein & 1814 & 8.39 \\
\hline
\end{tabular}

${ }^{1}$ \# indicates the number of transcripts

${ }^{2} \%$ indicates the percentage 


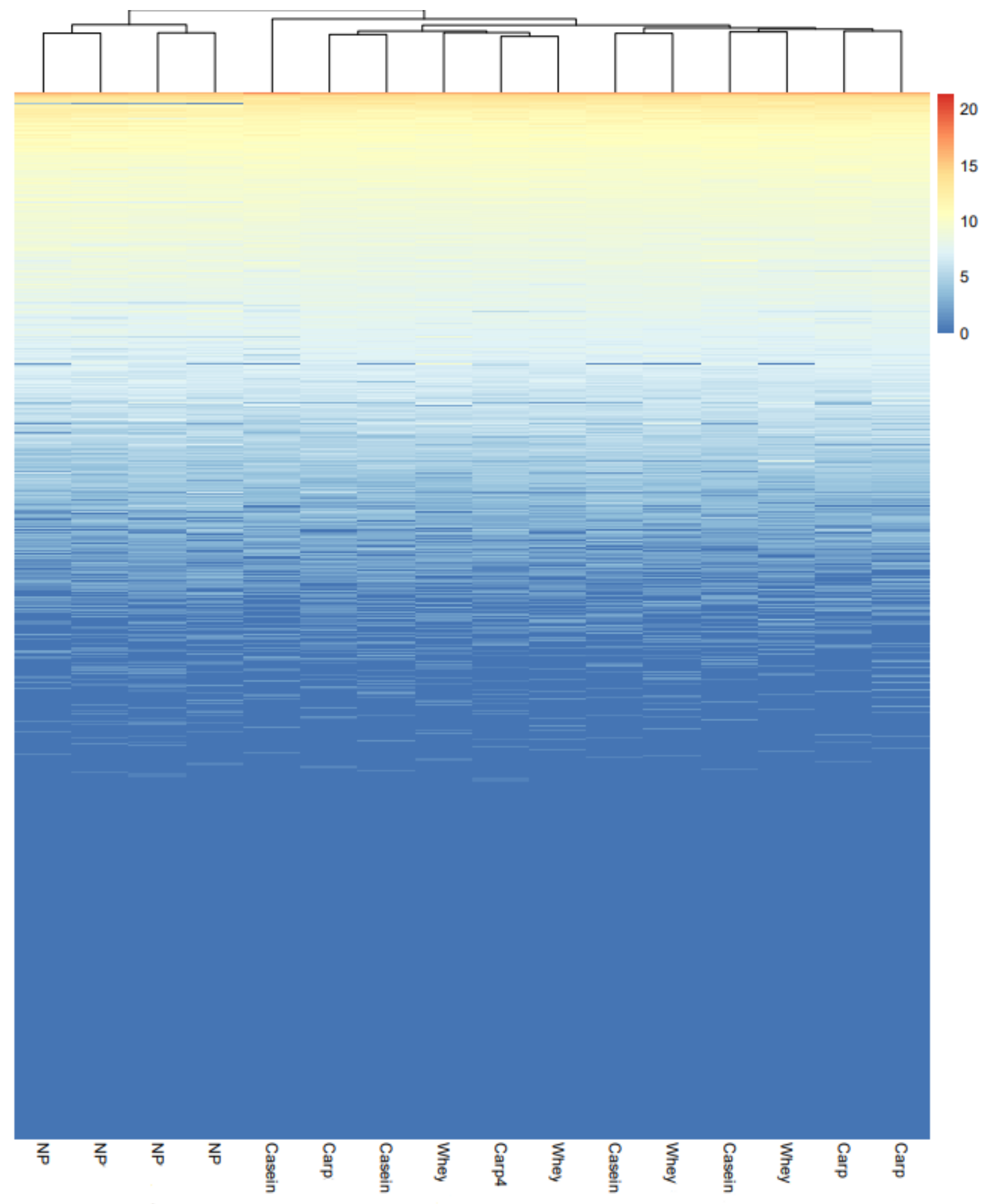

Figure 2: Hierarchical cluster analysis of expressed genes in rats fed $10 \%$ kcal protein diets of carp sarcoplasmic protein (carp), casein, or whey and no protein (NP) diets for 4 weeks. The level of expression was calculated by log transforming feature counts and compared among the diet groups $(n=4)$. Highly expressed transcripts are red, lowly expressed transcripts are blue. 


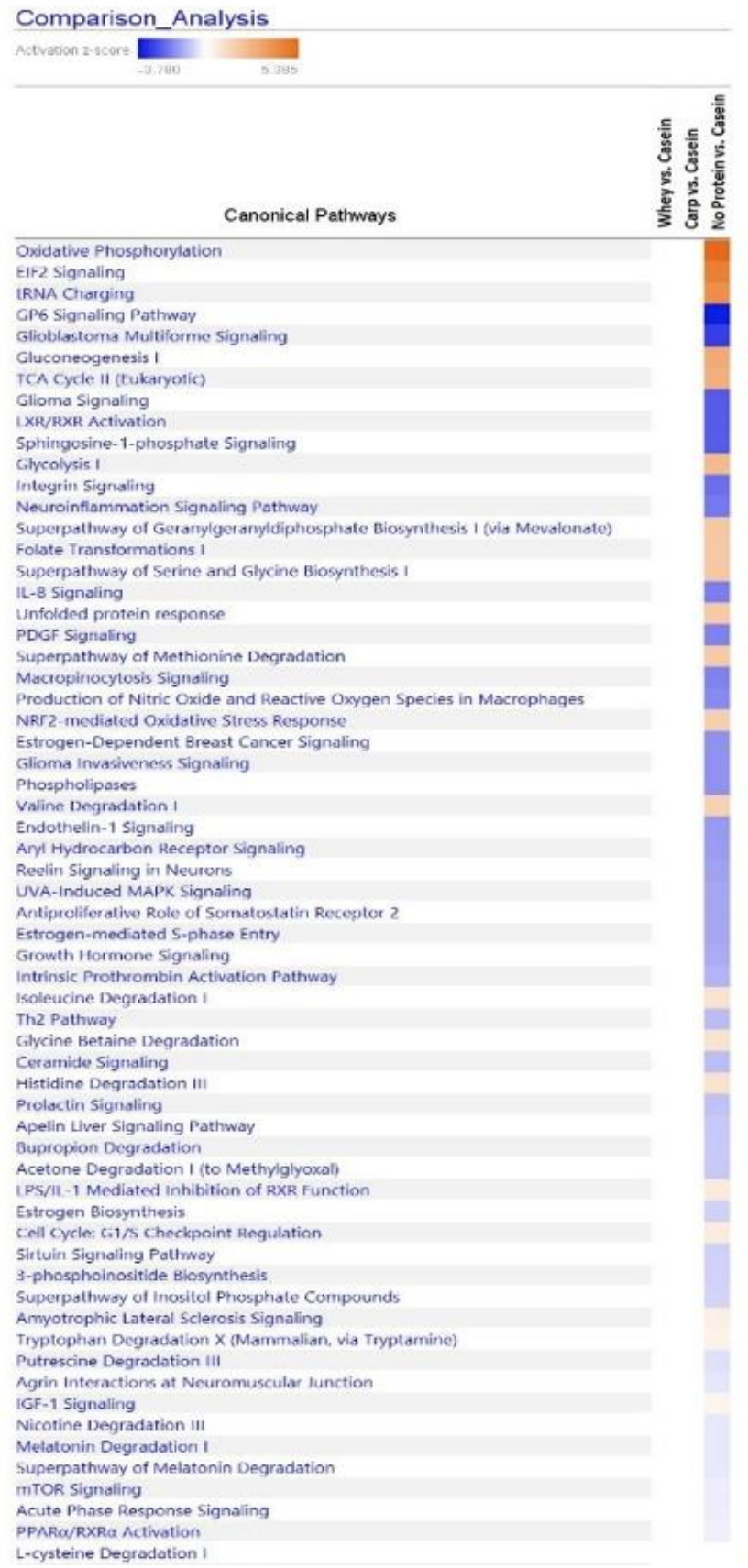

Figure 3: Comparison pathway analysis of differentially expressed genes in rats fed carp sarcoplasmic protein (carp), whey or no protein diets compared to rats fed casein as a control. Enriched pathways are red, suppressed pathways are blue. 


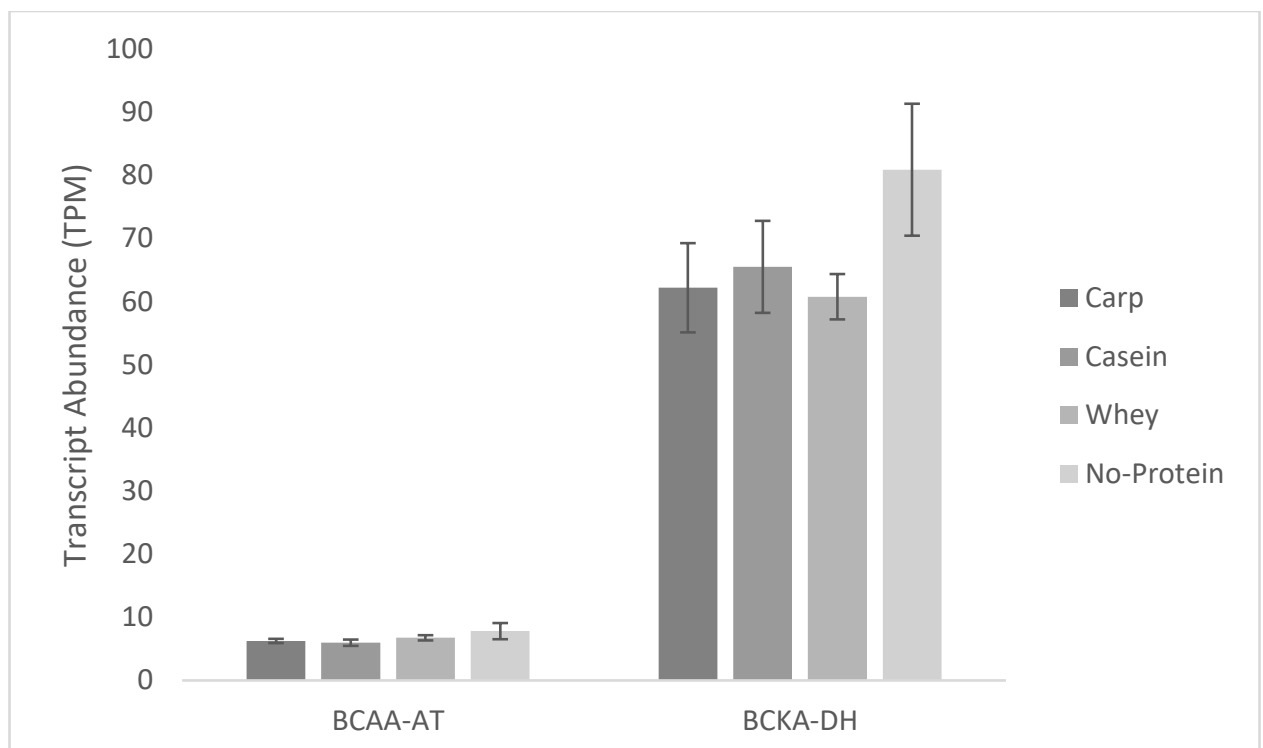

Figure 4: Effect of the consumption of different diets substituted with $10 \%$ kcal protein of carp sarcoplasmic protein (carp), casein or whey for four weeks on hepatic transcript abundance of genes involved in branch chain amino acid metabolism. Values expressed as mean \pm SEM ( $n=4$ rats/group). Abbreviations: BCAA-AT, branch chain amino acid aminotransferase; BCAA-DH, branch chain amino dehydrogenase. 


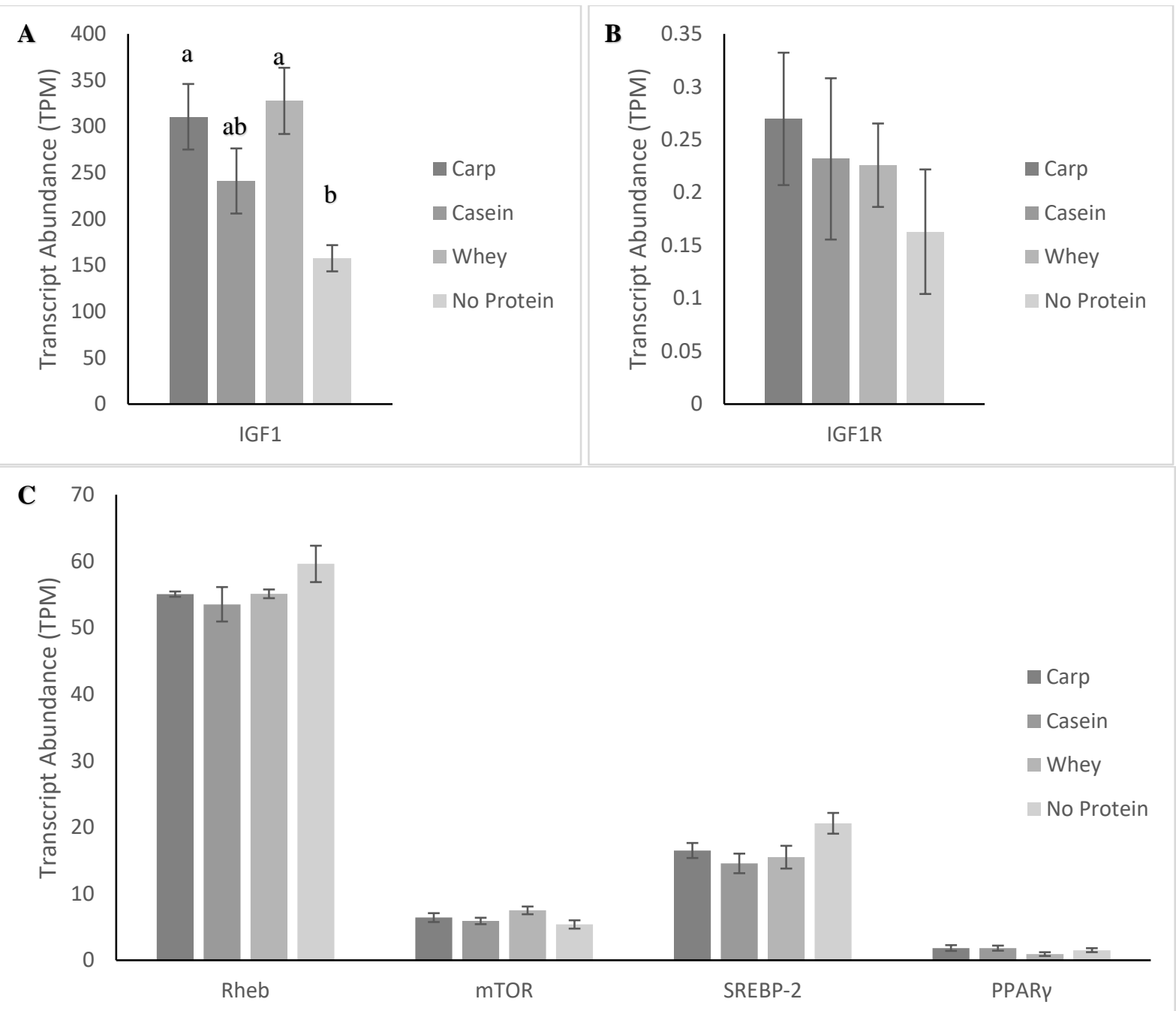

Figure 5: Effect of the consumption of different diets substituted with $10 \% \mathrm{kcal}$ protein of carp sarcoplasmic protein (carp), casein or whey for four weeks on hepatic transcript abundance of genes involved in the IGF-1 signaling pathway. Transcript abundance of insulin-like growth factor 1 (A), insulin like growth factor 1 receptor (B), and downstream regulatory molecules $(C)$ were characterized. Values expressed as mean \pm SEM $(n=4$ rats/group). Different letters a and $b$ indicate significant difference at $p<0.05$ by one-way ANOVA followed by Tukey's test. Abbreviations: IGF1, insulin-like growth factor 1; IGF1R, insulin-like growth factor 1 receptor; Rheb, Ras homolog enriched in brain; mTOR, mammalian target of rapamycin; SREBP-2, sterol regulatory binding protein-2; PPAR $\gamma$, peroxisome proliferator-activated receptor gamma. 


\section{Supplemental Table}

Table 5: Hepatic fatty acid composition and total lipid content after consuming diets substituted with $10 \%$ kcal protein of CSP, casein or whey protein for four weeks.

\begin{tabular}{|c|c|c|c|c|}
\hline \multirow[b]{2}{*}{ Measurements } & \multicolumn{4}{|c|}{ Treatments $^{1}$} \\
\hline & CSP & Casein & Whey & No-Protein \\
\hline \multicolumn{5}{|l|}{ SFAs (relative \%) } \\
\hline Palmitic acid 16:0 & $\begin{array}{c}19.12 \pm 1.57 \\
19.88 \pm\end{array}$ & $19.53 \pm 0.50$ & $18.17 \pm 1.58$ & $19.66 \pm 0.94$ \\
\hline $\begin{array}{l}\text { Stearic acid 18:0 } \\
\text { MUFAs (relative \%) }\end{array}$ & $1.29^{\mathrm{a}}$ & $15.28 \pm 1.71^{\mathrm{a}}$ & $18.45 \pm 0.79^{\mathrm{a}}$ & $6.77 \pm 0.43^{b}$ \\
\hline Palmitoleic acid 16:1 & $\begin{array}{c}1.03 \pm 0.40 \\
10.18 \pm\end{array}$ & $0.99 \pm 0.27$ & $0.95 \pm 0.15$ & $\begin{array}{c}1.19 \pm 0.08 \\
20.81 \pm\end{array}$ \\
\hline Oleic acid $18: \ln 9 \mathrm{c}$ & $1.99^{\mathrm{b}}$ & $10.64 \pm 1.96^{\mathrm{b}}$ & $11.70 \pm 0.94^{\mathrm{b}}$ & $1.29^{\mathrm{a}}$ \\
\hline PUFAs (relative \%) & & & & \\
\hline Linoleic acid 18:2n6c & $\begin{array}{c}11.74 \pm \\
1.31^{\mathrm{b}}\end{array}$ & $11.26 \pm 2.07^{\mathrm{b}}$ & $10.34 \pm 0.62^{b}$ & $\begin{array}{c}23.21 \pm \\
1.67^{\mathrm{a}}\end{array}$ \\
\hline$\alpha$-linoleic acid C18:3n3 & $0.56 \pm 0.06^{\mathrm{b}}$ & $0.64 \pm 0.10^{\mathrm{b}}$ & $0.49 \pm 0.04^{\mathrm{b}}$ & $1.56 \pm 0.09^{\mathrm{a}}$ \\
\hline Arachidonic acid C20:4n6 & $0.00 \pm 0.00$ & $0.00 \pm 0.00$ & $0.00 \pm 0.00$ & $0.14 \pm 0.03$ \\
\hline Eicosapentaenoic acid C20:5n3 & $0.00 \pm 0.00$ & $0.00 \pm 0.00$ & $0.00 \pm 0.00$ & $0.00 \pm 0.00$ \\
\hline Docosahexaenoic acid 22:6n3 & $0.00 \pm 0.00$ & $0.00 \pm 0.00$ & $0.00 \pm 0.00$ & $0.00 \pm 0.00$ \\
\hline Total Lipid Content (\%) & $6.91 \pm 0.99^{b}$ & $8.73 \pm 1.85^{\mathrm{b}}$ & $4.62 \pm 0.99^{\mathrm{b}}$ & $\begin{array}{c}19.96 \pm \\
4.13^{\mathrm{a}}\end{array}$ \\
\hline
\end{tabular}




\section{Chapter VI}

\section{Summary and Future Directions}

\section{Summary}

During processing of silver carp, water-soluble sarcoplasmic proteins lost in wash water, were recovered and freeze-dried into a protein-rich powder, CSP. For commercial and consumer acceptance, protein quality and safety of CSP must be evaluated by comparing CSP to popular commercially available proteins, casein and whey protein. Study $\mathbf{1}$ assessed the protein quality of CSP and effects of low (10\% kcal) protein diets consisting of CSP, casein, and whey protein on growth, body composition, renal markers, and bone health. Results indicated protein quality of CSP was comparable to casein and whey protein. Further feeding low (10\% kcal) protein diets supported rat growth within the normal range; however, whey protein-fed rats had greater gonadal adipose weight. Study 2 investigated low protein $(10 \% \mathrm{kcal})$ diets consisting of CSP, whey protein or casein effects on lipid metabolism in adipose tissue and liver compared to a protein-energy malnutrition diet. Results demonstrated CSP and casein and did not result in altered expression of genes regulating adiposity or liver lipid metabolism contributing to development of NAFLD. However, it has been suggested that whey protein consumption stimulates insulin and IGF-1 secretion, resulting in adipogenesis. Therefore, Study $\mathbf{3}$ assessed distinct hepatic transcriptome responses due to low protein $(10 \% \mathrm{kcal})$ diets supplemented with CSP, casein, and whey protein compared to a protein-free diet. RNA sequencing of hepatic tissue revealed consumption of the protein-free diet resulted in the greatest number of differentially expressed genes compared to casein while CSP and whey protein consumption increased the abundance of IGF-1 transcripts. 
Based on the results of the three studies, we concluded:

1. Carp protein powder derived wash water provides a source of high-quality protein that may contribute to improved sustainability by reducing amount of protein consumed to support adequate body growth without affecting renal and bone health.

2. CSP is a physiologically safe option but may be preferable to whey protein for preventing increased adiposity without detrimental effects on the liver and therefore, could be marketed as a sustainable alternative to current commercial protein powder. 3. In low protein diets reduced protein content to $10 \% \mathrm{kcal}$ did not cause significant alterations to hepatic transcriptome. However, greater hepatic expression of IGF-1 in whey-fed rats can affect nutrient storage in extrahepatic tissues.

\section{Future Direction}

Further studies are needed to investigate whether reduced protein diets sources from carp, casein, and whey alter nutrient storage in extrahepatic tissues by assessing transcriptome responses in adipose tissue. Additional CSP safety studies are needed to assess allergic response elicitation and potential heavy metal effects. Future pilot plant studies should investigate alternative recovery and drying methods to improve processing efficiency. Finally, product formulation testing should be done in order to bring the silver carp derived protein powder to market. 